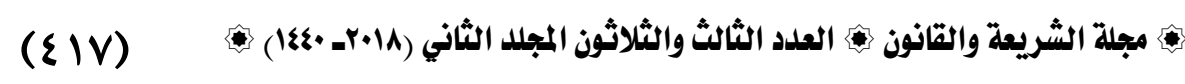
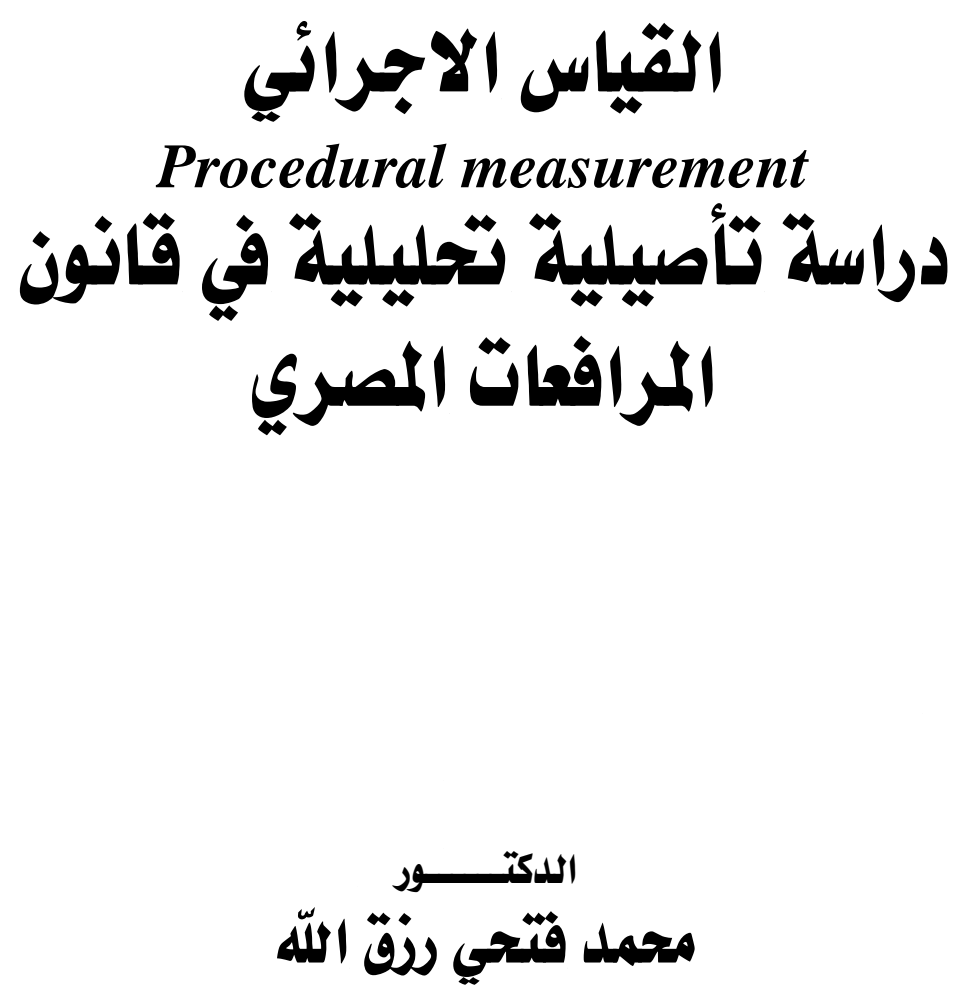

ملرسر قانوك المرافحات بكلية الشريخة والقانوق،جامحة الأزهر 


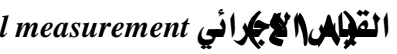




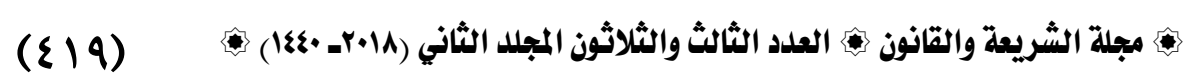

\section{القياس الإجرائي}

لما كان مـن الطبيعي آن ينـال الفـراغ التشريعي النص التص القـانوني

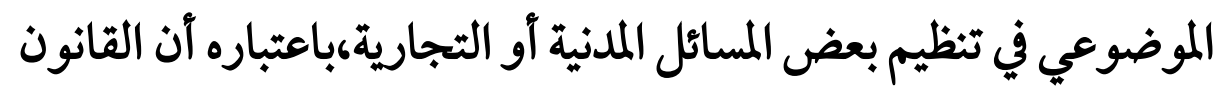

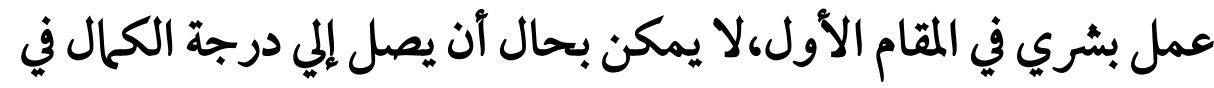

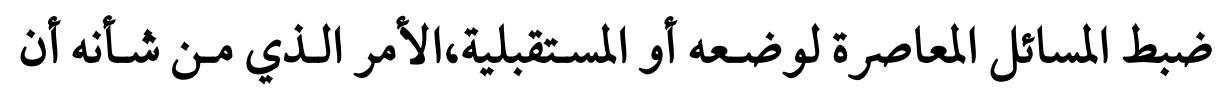

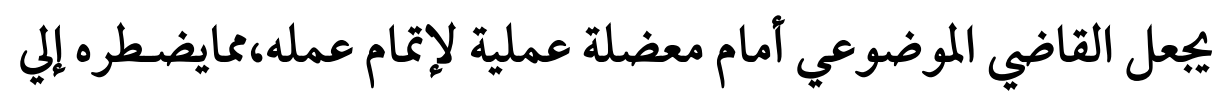

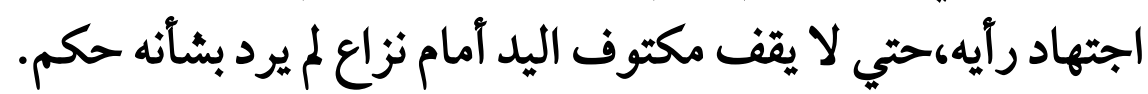

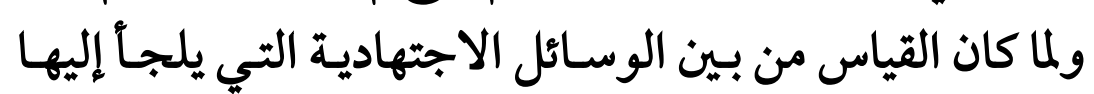

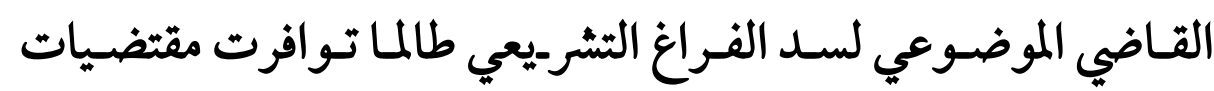

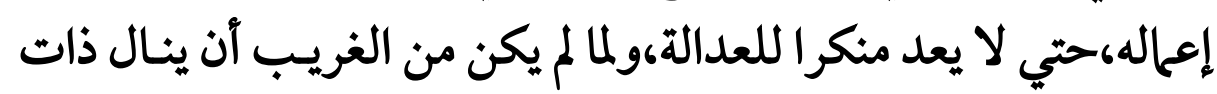

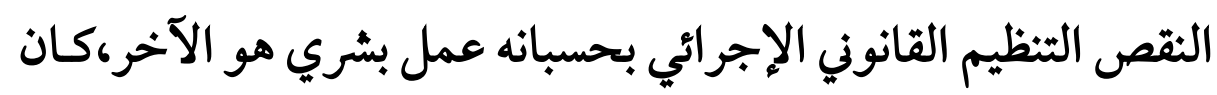

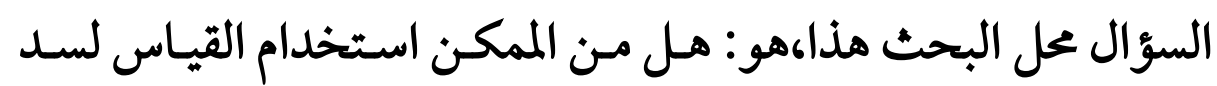

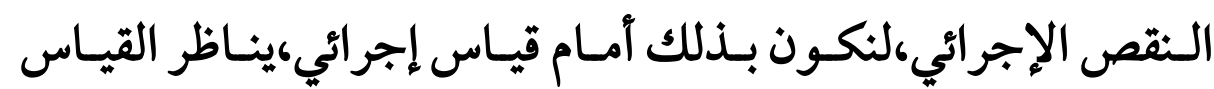

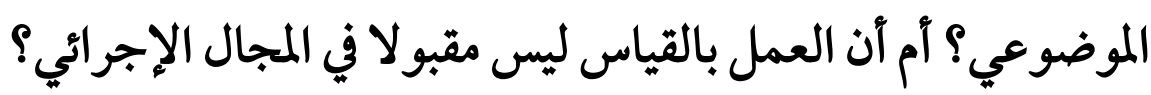

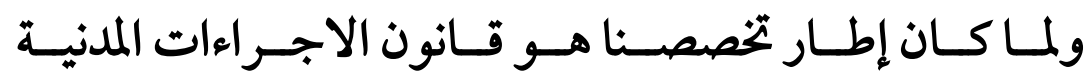
والتجارية،فقد قمت ببحث هذه المسألة في حدود هذا التخصصص، فـدون

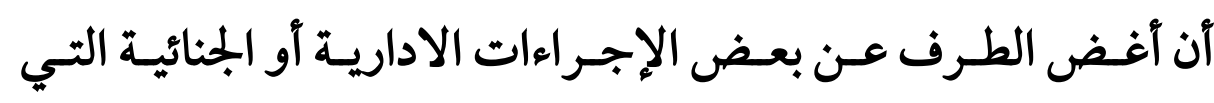

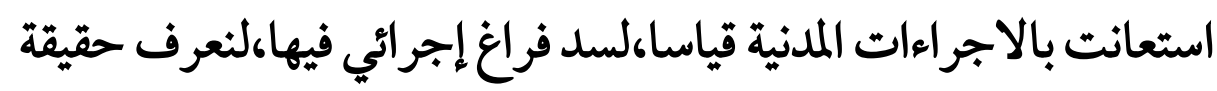
الاستعانة هذه. 


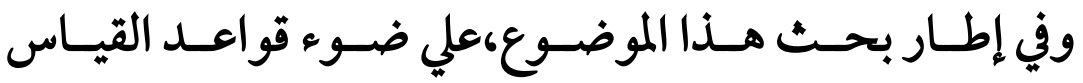
الأصولي،فقد استطعنا التوصل إلي تعريف للقياس الاجرائي،كاء أمكن

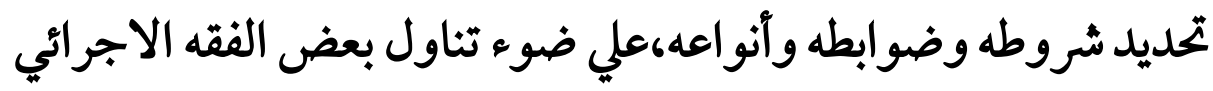

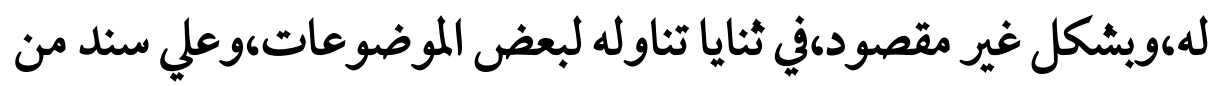

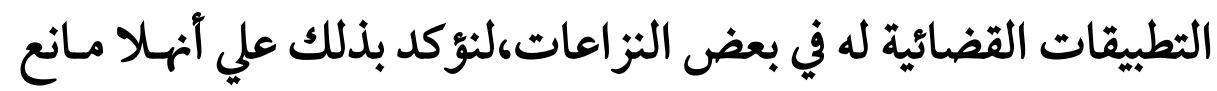

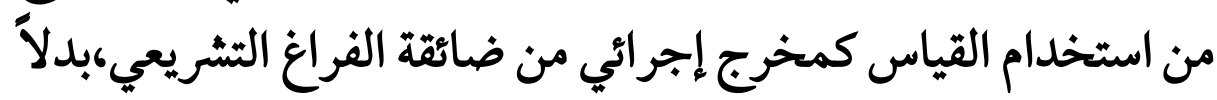
من رفض استخدامه،فنصد عن تحقيق العدالة في جانب من النزاعات، مناميا

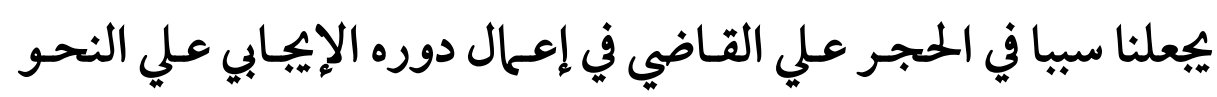

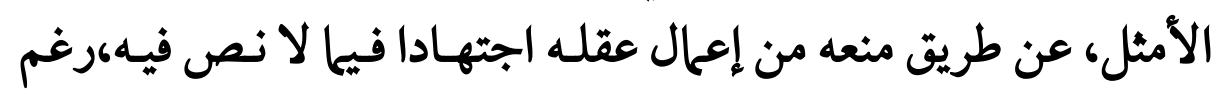

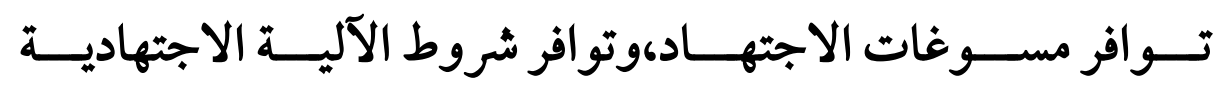

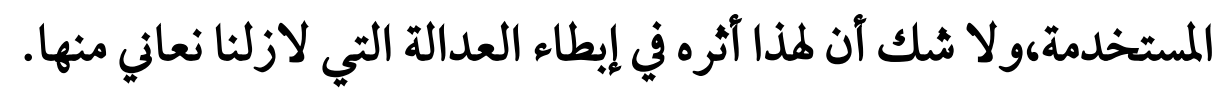




\section{The Procedural measurement}

Since it was natural for the legislative vacuum to obtain the substantive legal text in the regulation of certain civil or commercial matters, On the basis that the law is human work in the first place, cannot possibly be perfect in controlling the contemporary issues of its status or future, Which would make the objective judge a practical problem to complete his work, forcing him to try his opinion, so as not to stand idly by in a dispute for which no provision was made

As the measurement is among the means of discretion used by the objective judge to fill the legislative vacuum as long as the requirements for its implementation, So as not to be a denier of justice, It is not surprising that the lack of legal organization is a matter of human action as well.Based on the above, the research question was: Is it possible to use the measurement to fill the procedural gap, so to be in front of a procedural measure, corresponding to objective measurement? Or is it not acceptable to work in the procedural field?

Since the framework of our specialization is the Code of Civil and Commercial Procedure, I have examined this issue within the limits of this specialization, without turning a blind eye to some administrative or 
criminal procedures that have used civil procedures in comparison to fill a procedural void in them in the light of the rules of the fundamental measurement in Islamic jurisprudence, we have been able to reach a definition of procedural measurement, and it was possible to determine its conditions and controls and types, in light of the handling of some procedural jurisprudence, and unintentionally, in the folds dealt with some topics, Of its judicial applications in some disputes. In order to emphasize that there is no objection to the use of measurement as a procedural output of the legislative vacuum, rather than rejecting it, we will stop justice in a part of the conflict. This makes us a reason to quarantine the judge in his positive role by preventing him from Despite the availability of the reasons, and the availability of the requirements of the mechanism of jurisprudence used, and this undoubtedly has the effect of slowing the justice we still suffer from, 


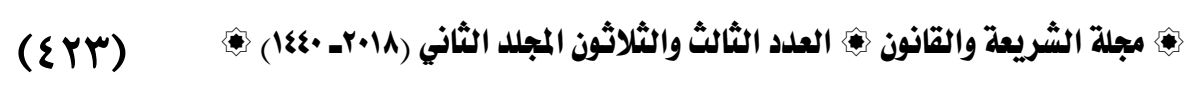

مقدمة

الحمد الله الذي خلق خلقه أطوارا، وصرفهم في أطوار التخليق

كيف شاء عزة واقتدارا، وآرسل الرسل إلى المكلفين إعذارا منه وإنذارا، فنصب الدليل، وأنار السبيل، وأزاح العلل، وقطع المعاذير، وقال:رهذا صراطي مستقيا فاتبعوه ولا تتبعوا السبل\{'،وهؤلاء رسلي \}مبشرين ومنذرين لئلا يكون للناس على الله حجة بعد الرسل \{' . فاضل بين عباده في مراتب الكهال حتى عدل الآلاف المؤلفة منهم بالرجل الواحد،ذلك ليعلم عباده أثه أنزل التوفيق منازله، ووضع الفضل مواضعه، روآن الفضل بيد الله يؤتيه من يشاء والله ذو الفضل العظيمج '.أحمده والتوفيق للحمد من نعمه، وآشكره والشكر كفيل بالمزيد من فضله،وآشهد آن عحمدا عبده ورسولهالذي لم يزل مشمرا في ذات الله تعالى لا يرده عنه راد، صادعا بأمره لا يصده عنه صاد، إلى آن آشرقت برسالته الآرض بعد ظلماتها، وتألفت به القلوب بعد شتاتها،فلما أكمل الله تعالى به الدين، وآثم به النعمة على عباده المؤمنين، استأثر به ونقله إلى الرفيق الأعلى، والمحل الأسنى، وقد ترك آمته علي الطريق الواضحة الغراء، فصلى الله

$$
\begin{aligned}
& 1 \\
& \text { r ـ سورة النساء، آية } 170 \\
& \text { r _سورة الحديد، الآية }
\end{aligned}
$$


وملائكته وأنياؤه ورسله والصالحون من عباده عليه وآله كما وحد الله

$$
\text { وعرف به ودعا إليه وسلم تسليا كثيرا' ،وبعد... }
$$

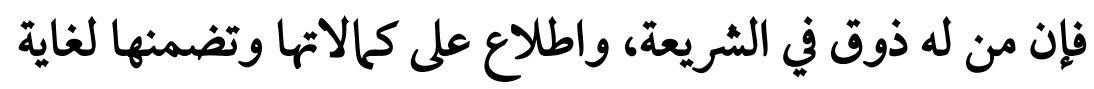

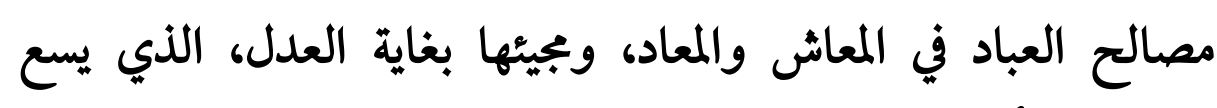

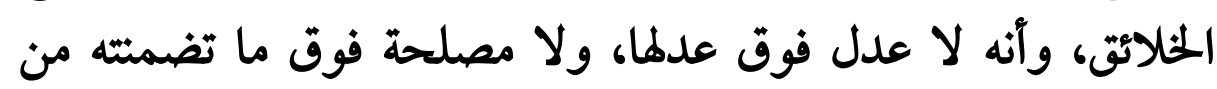

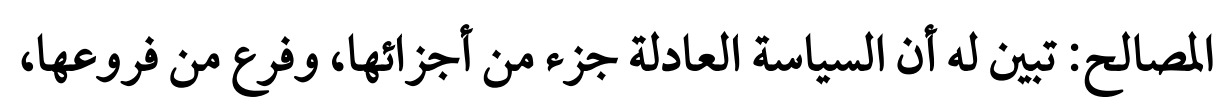

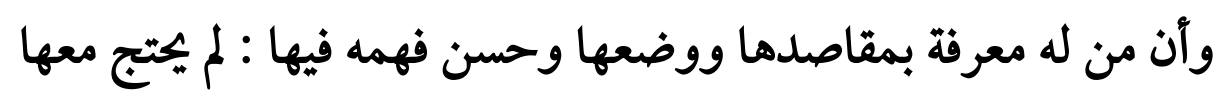

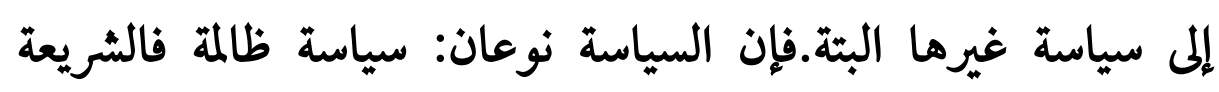

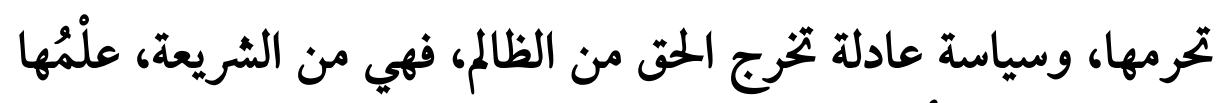
من علْمِها، وجهلُها من جهلِها'.

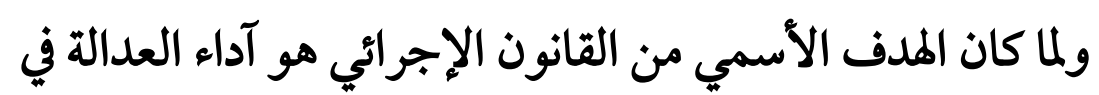

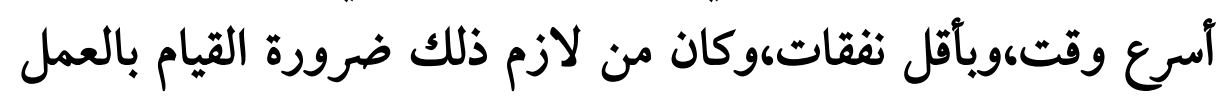

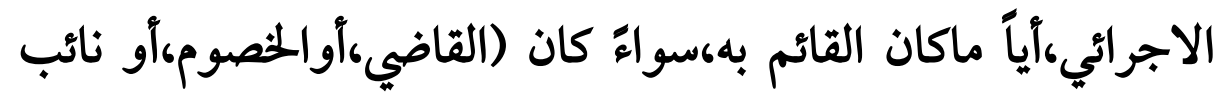
الخصم،أو أعوان القضاة) في الشكل المتطلب قانونا، ولمان كانت الأشكال

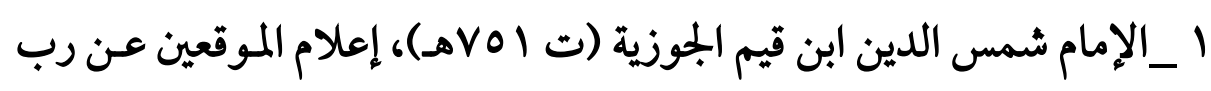

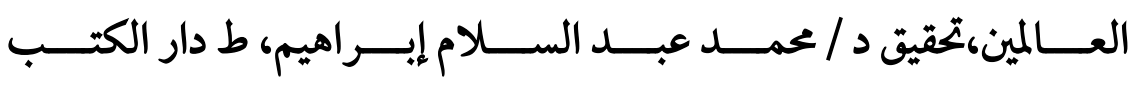

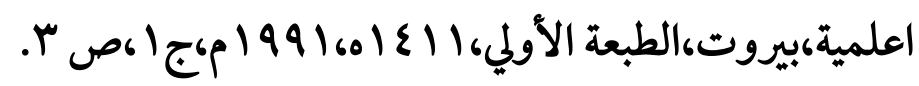

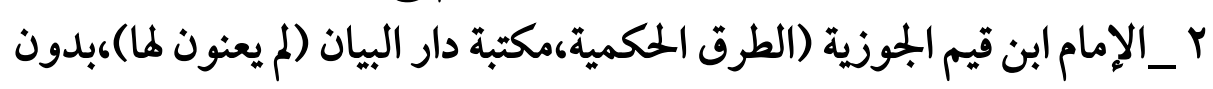

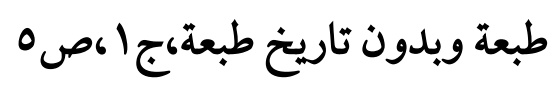




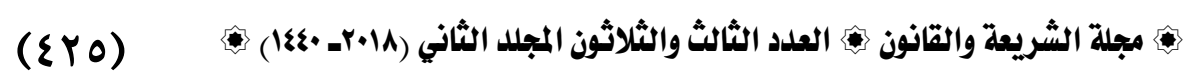
الاجرائية محددة لكل عمل صراحة،أو إحالة،كان ذلك سبباً في إنكار

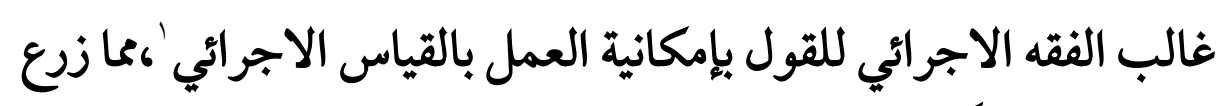

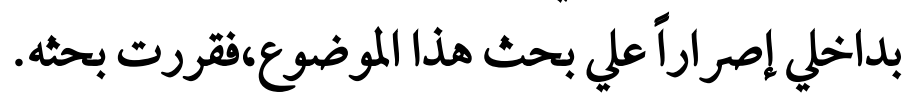

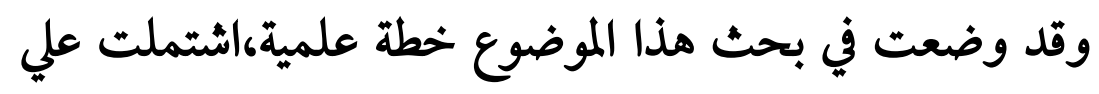

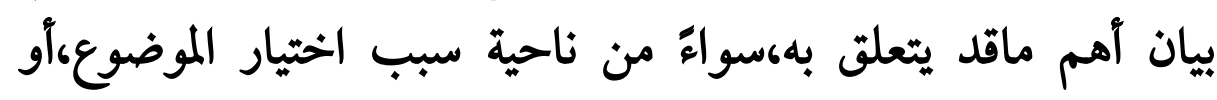

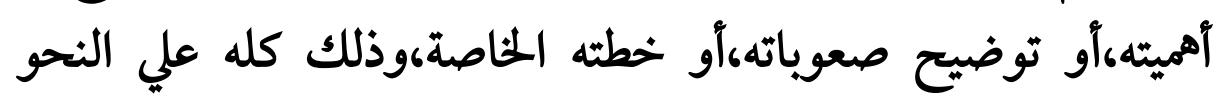
الآتي:

سبب إختيار الموضوع : يرجع سبب اختيار هذا الموضوع ليكون عنواناً للبحث إلي سبين رئيسيين،وهما:

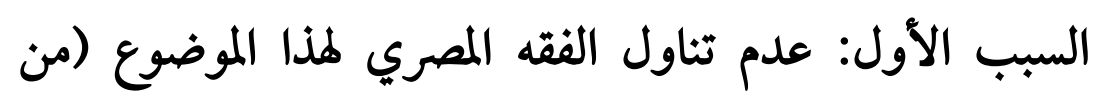

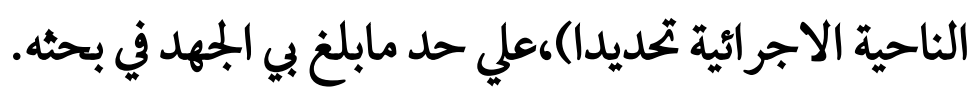

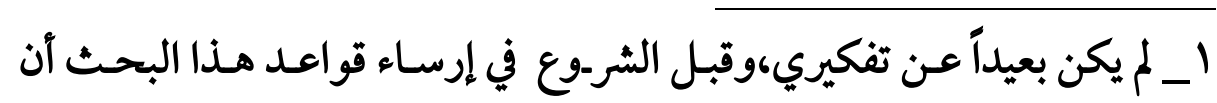

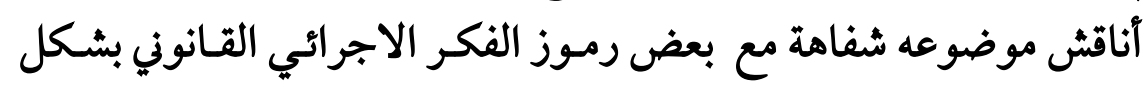

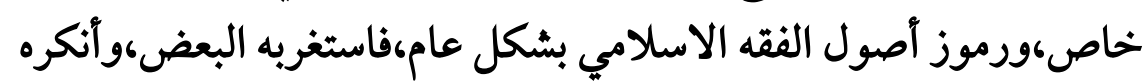

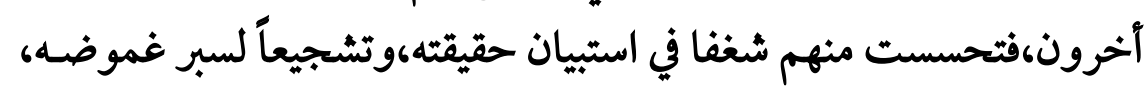

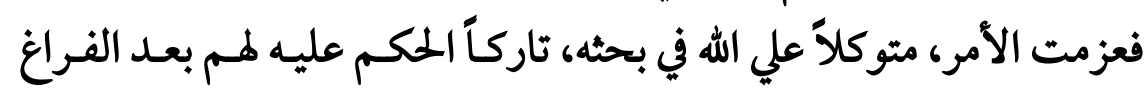

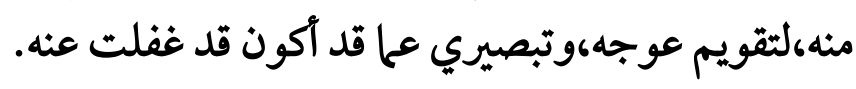


السبب الثاني : إنكار غالبية الفقه الاجرائي لوجود مثل هذه

الفكرة بين قواعد قانون الاجراءات المدنية والتجارية،ويالتالي محاولة الوصول إلي مدي صحة ذلك.

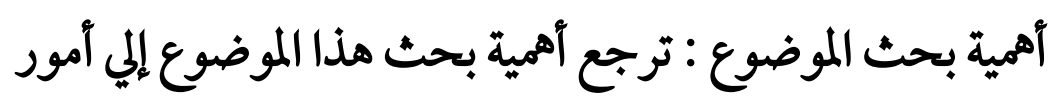

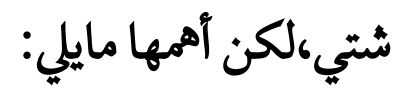
الأهمية الأولي : وتتمثل في أهمية القياس ذاته،باعتباره وسيلة

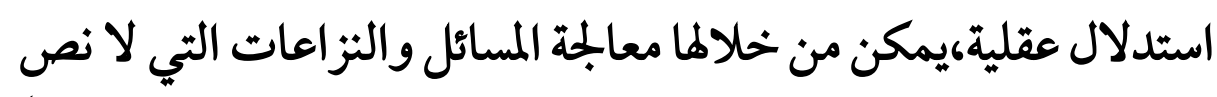

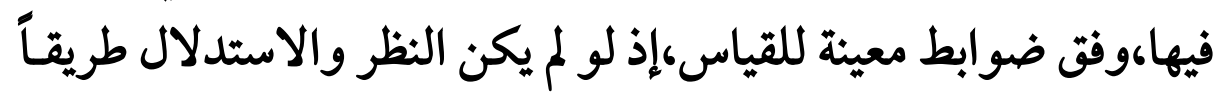

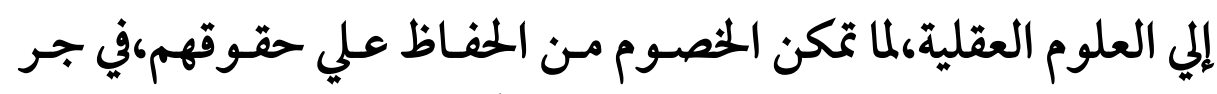

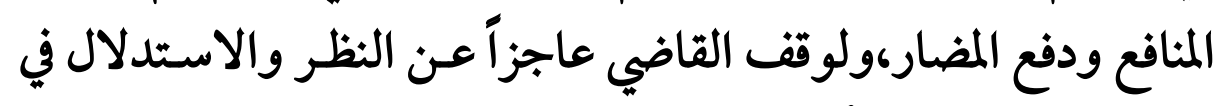

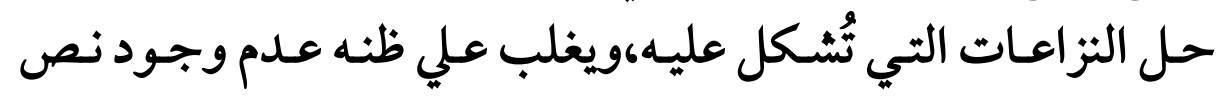

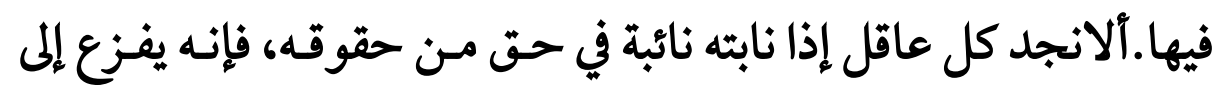

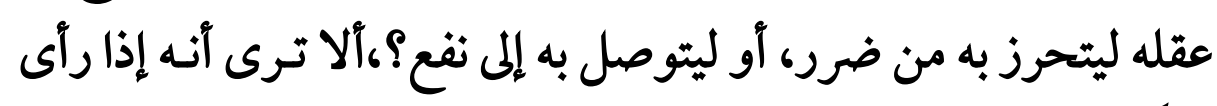

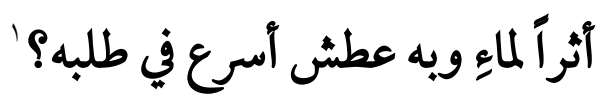

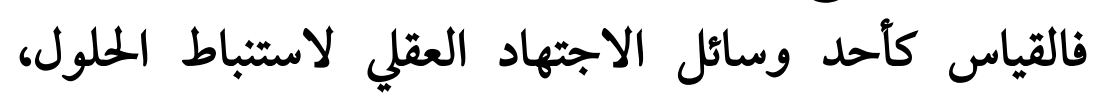

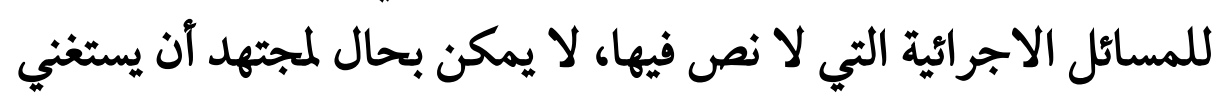

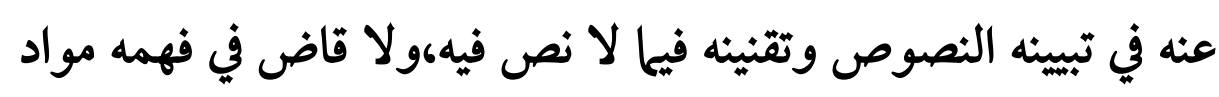

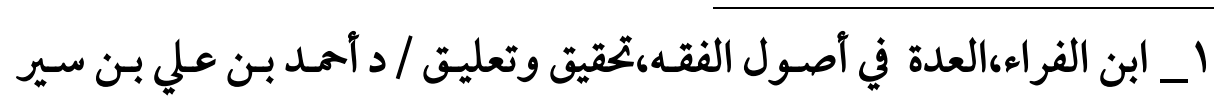

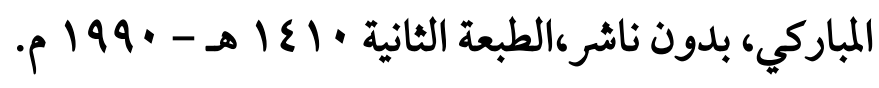




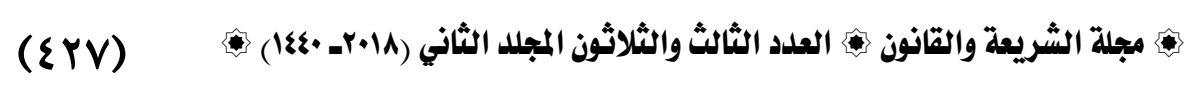

القانون حق فهمها، وتطبيقها التطبيق الذي يحقق العدل وما قصده

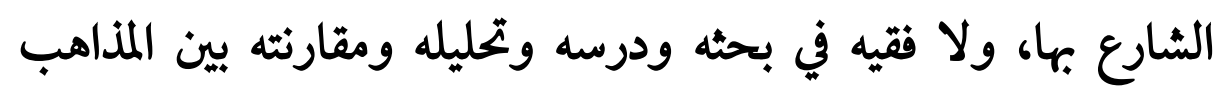

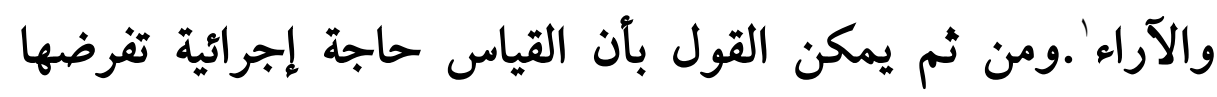

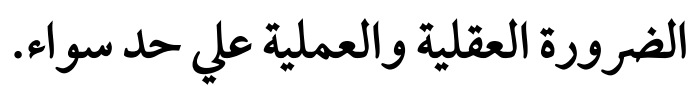

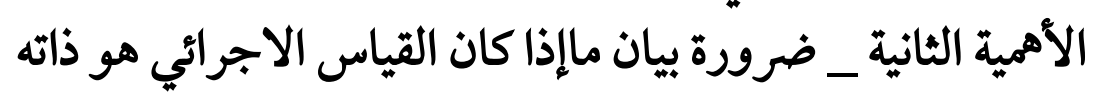

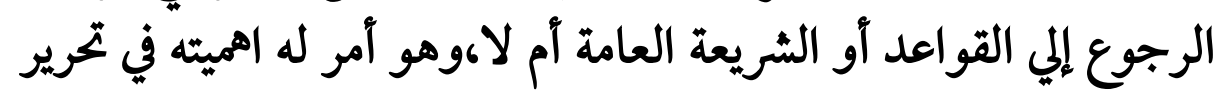

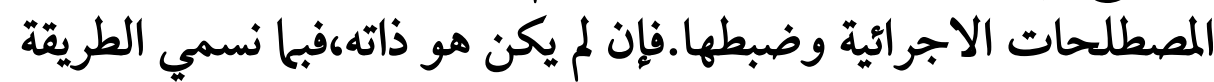

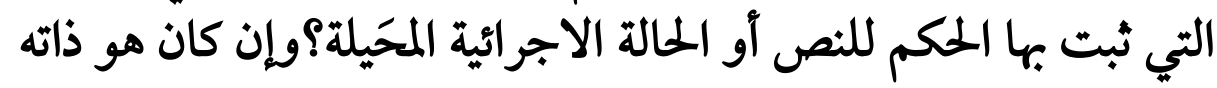

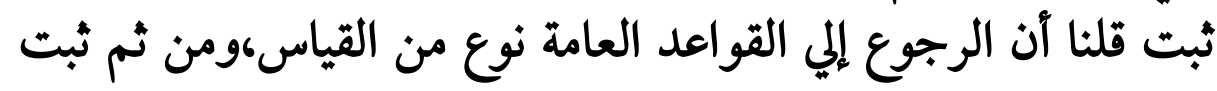
استخدام القياس. منهج البحث :

لطبيعة البحث، الذي تطلب استقراءة متأنياً، وتحليلاً مناسباً،

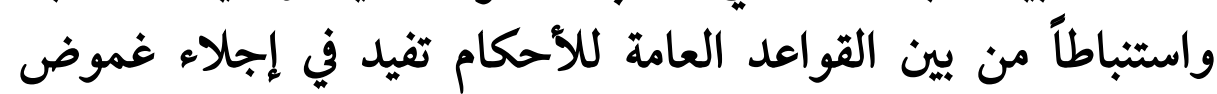
البحث، كان منهجي في البحث هو المنهج الاستثاطثائي التحليلي الاستنباطي.

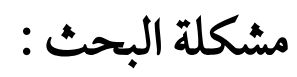

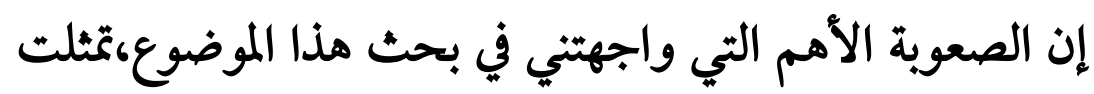

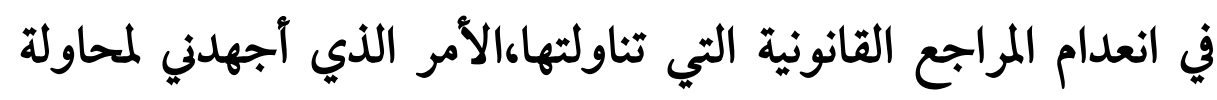

1_ عبد الوهاب خلاف، علم أصول الفقه،مكتبة الدعوة،الطبعة الثامنة، بـدون تاريخ نشر،ص V. 
تأصيلها قانونياً،لا سيا في ظل إنكار غالبية الفقه الاجرائي المصري للفكرة من الأساس.

خطة البحث الخاصة: لما كان الغرض الأصلي، والمقصـود الكلي

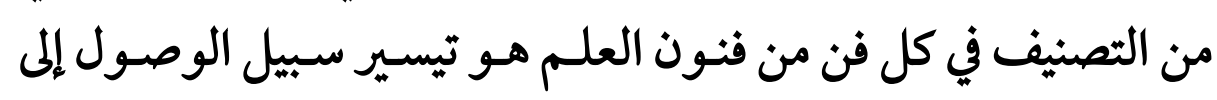

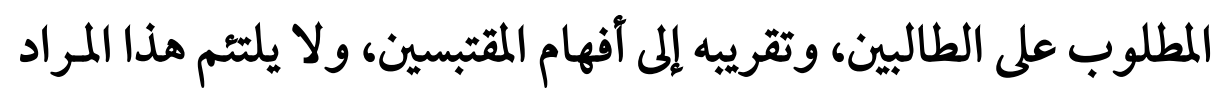

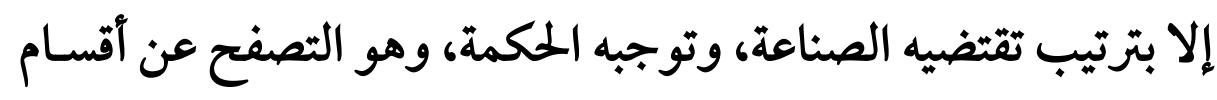

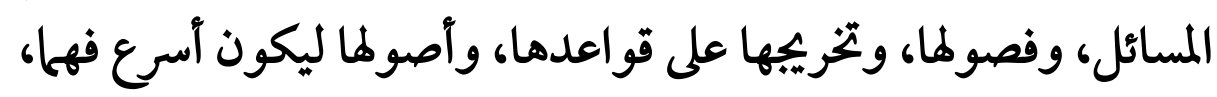

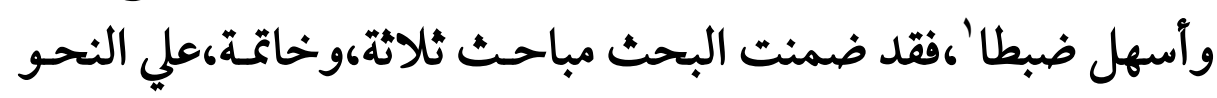
الآتي :

المبحث الأول: حقيقة القياس وموقف الفقه الاجرائي والقضاء

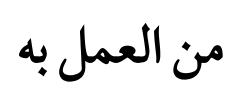

المطلب الأول : حقيقة القياس في الفقه الاسلامي

$$
\text { الفرع الأول : تعريف القياس لغة واصطلاحاً }
$$

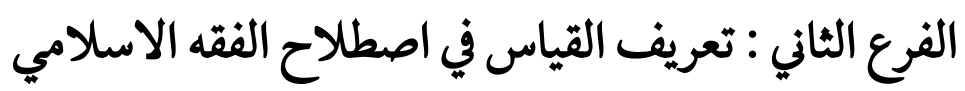

الفرع الثالث : علاقة المعني الفقهي الاسلامي للقياس

$$
\text { بالاجراءات القضائية العملية }
$$

الفرع الرابع:أركان القياس وفقاً لمفهومه في الفقه الاسلامي

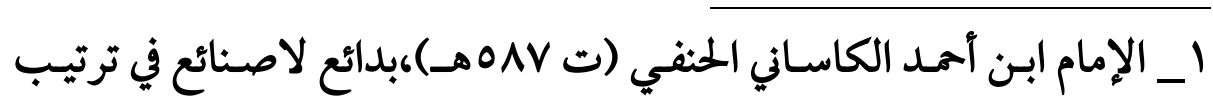

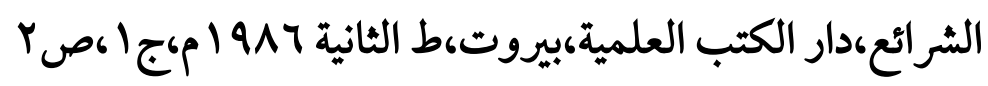




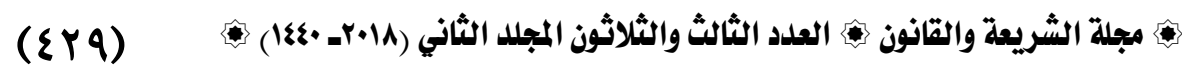

المطلب الثاني : موقف الفقه الاجرائي والقضاء من العمل

بالقياس بذات معناه في الفقه الاسلامي

الفرع الأول : هل عرف الفقه الاجرائي القانوني القياس بذات

معناه في الفقه الاسلامي؟

الفرع الثاني : هل استخدم القضاء الاجرائي القياس بذات معناه

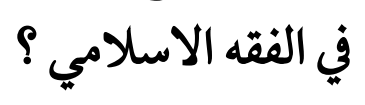

الفرع الثالث :تعريف القياس الاجرائي في ضوء موقف الفقه

$$
\text { والقضاء الاجرائين،وبيان أركانه. }
$$

الفرع الرابع :أساس العمل بالقياس الاجرائي،

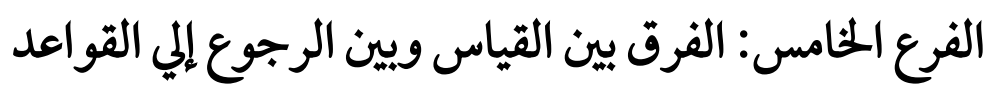

العامة.

المبحث الثاني : أنواع القياس الاجرائي وشروط العمل به.

المطلب الأول: أنواع القياس الاجرائي

الفرع الأول: القياس الاجرائي الجلي

الفرع الثاني: القياس الاجرائي الخفي

الفرع الثالث: قياس الشبه الاجرائي

الفرع الرابع: قياس العكس الاجرائي

المطلب الثاني : شروط العمل بالقياس الاجرائي.

الفرع الأول : الشروط المتعلقة بالأصل (المقيس عليه) 
الفرع الثاني:الشروط المتعلقة بالفرع(المقيس)

الفرع الثالث:الشروط المتعلقة بحكم الأصل

الفرع الرابع: الشروط المتعلقة بالعلة

خاتمة البحث :

أولاً: أهم نتائج البحث البحث

ثانياً: أهم توصيات البحث البحث 


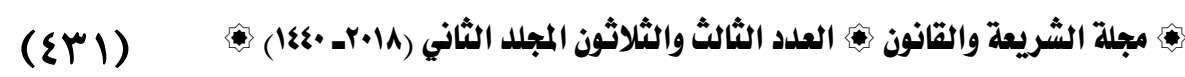

\section{المبحث الأول \\ حقيقة القياس وموقف الفقه الاجرائي والقضاء}

\section{من العمل بله}

ويتطلب هذا المبحث منا آن نعرض آولاً لتعريف القياس لدي

الفكر الاسلامي،ثم نبين موقف الفكر القانوني الاجرائي من فقه وقضاء

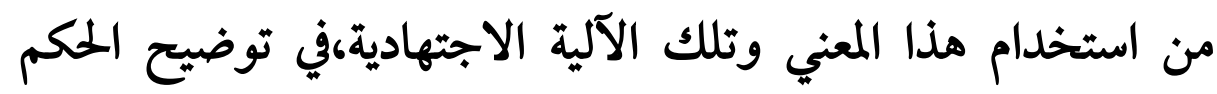

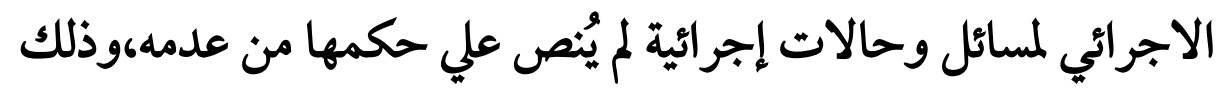

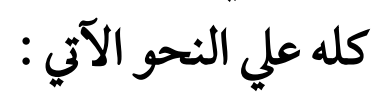

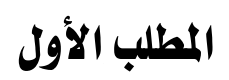

تصريف القياس في الفقه الاسلامي الاول

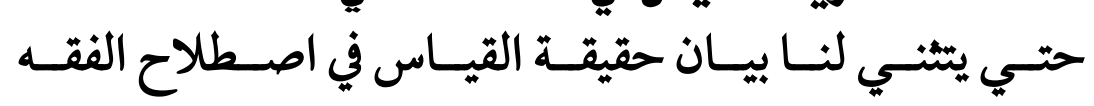

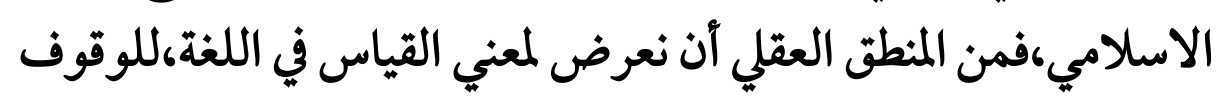

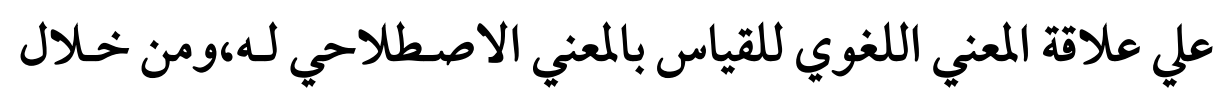

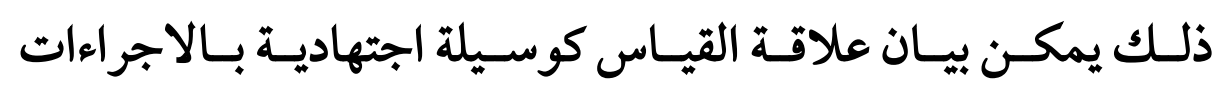
القضائية،ومن ثم يمكن أن نقف علي حقيقة القياس الاجرائي،وذئك

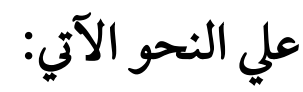




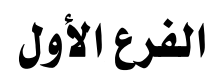 \\ معني القياس في اللفة الأول}

من معاني القياس في اللغة: التقـدير '،أي تقـدير شـيـع علي مثـال

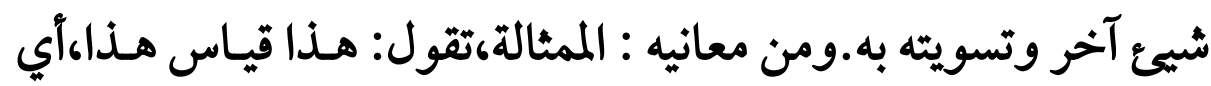

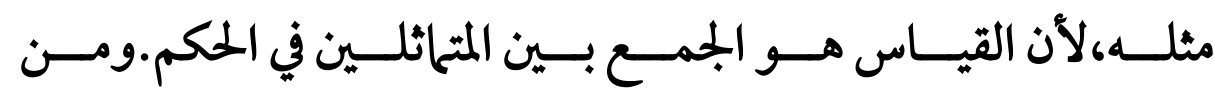

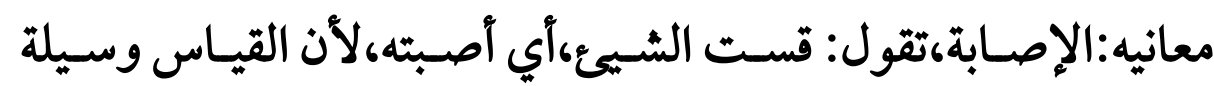

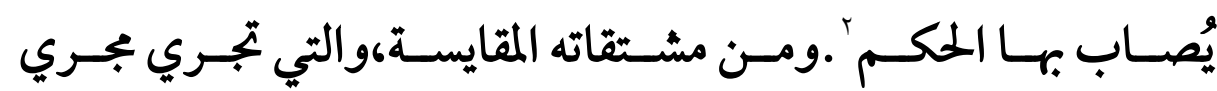

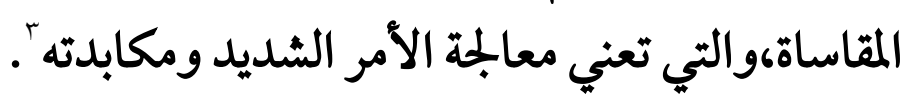

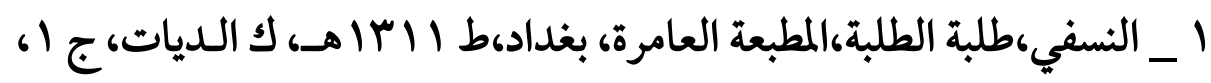
ص

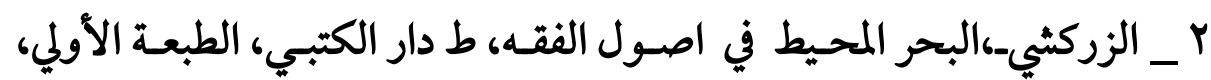
(1)

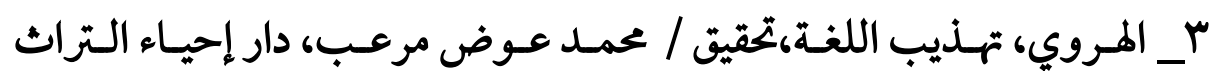

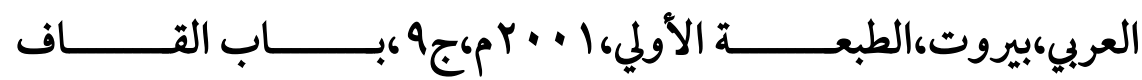

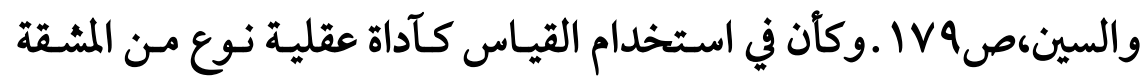

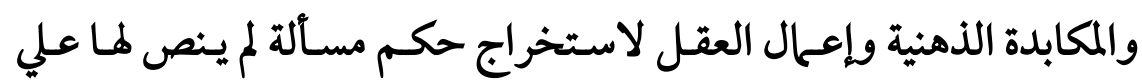
حكم،وهو أمر حقيقي في الواقع. 


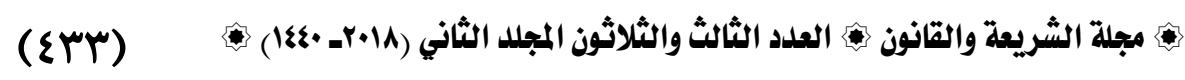

$$
\text { الفرع الثاني }
$$

معني القياس في اصطلاح الثقة الاسلامي

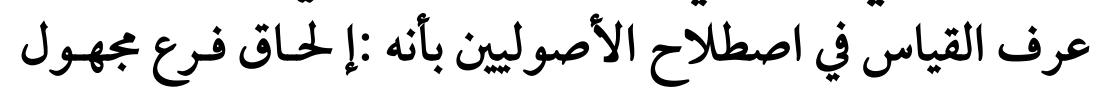

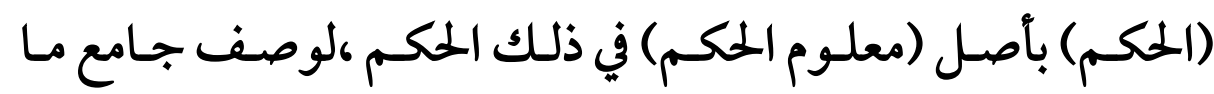

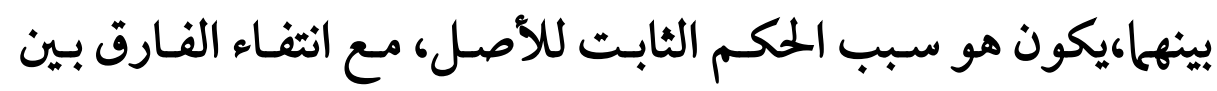

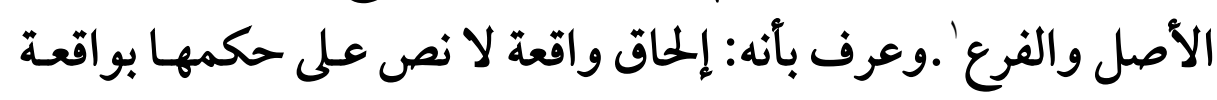

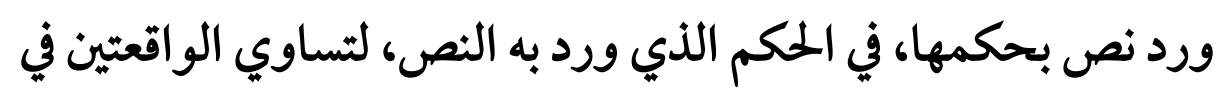

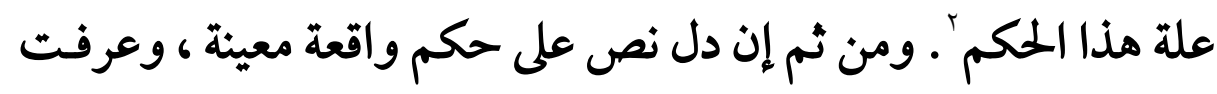

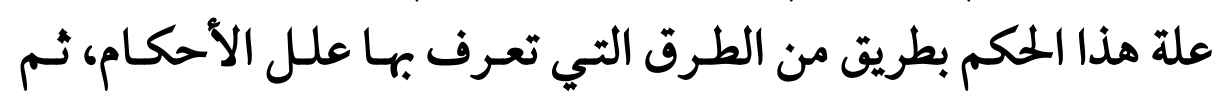
وجدت واقعة أخرى تساوي واقعة النص على علة تحقق علة الحكمى فيها

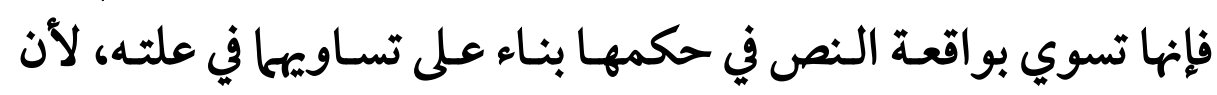

$$
\text { الحكم يو جد حيث توجد علته. }
$$

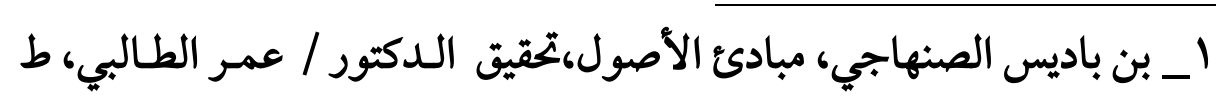

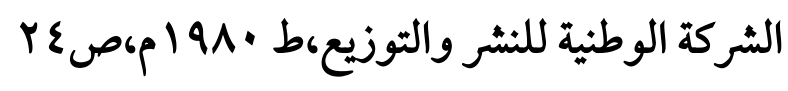

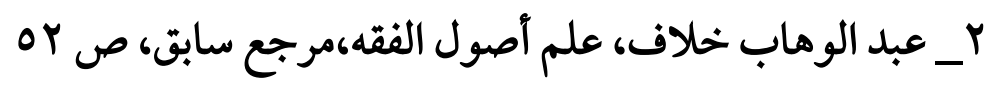




\section{الفرع الثالث الثماثي

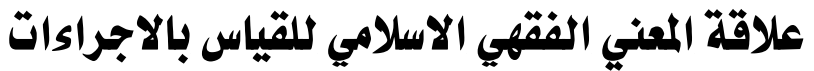

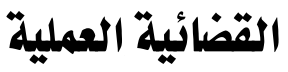

لما كان قانون الاجراءات المدنية قانون شكليكيهدف بشكل

أساسي إلي تنظيم عملية التقاضي،بدءا من عملية رفع الدعوي

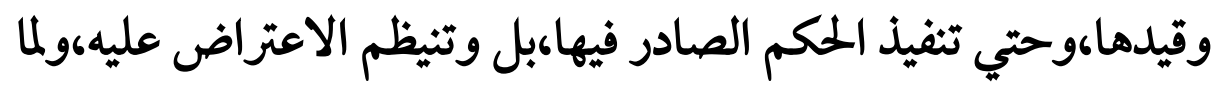

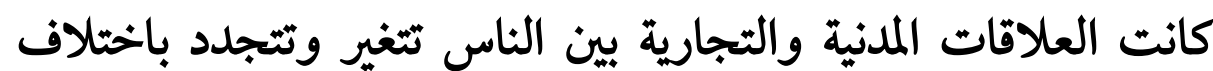

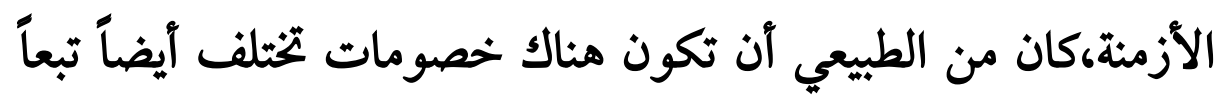

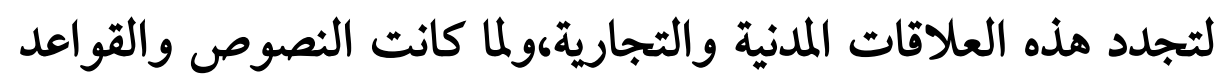

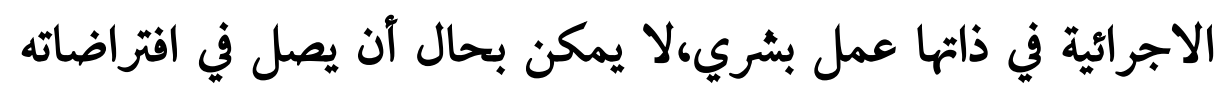

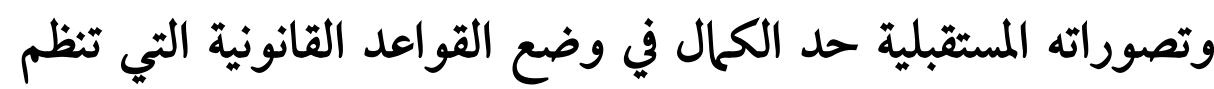
عملية الثقاضي. ولما كان تطبيق القانون علي وجهه الصحيح لا يحتاج إلي طلب من

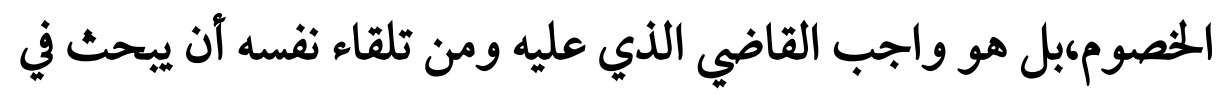

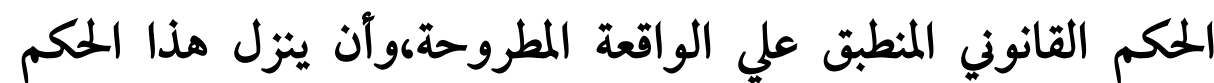

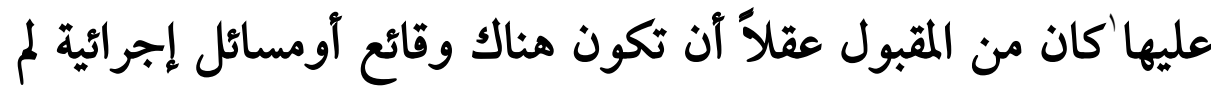
تُنظم،وبالتالي نجد أنفسنا أمام مائسمي بالفراغ آو النقص التهول التشريعي.

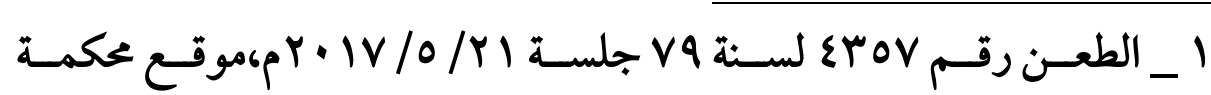
النقض،الأحكام. 


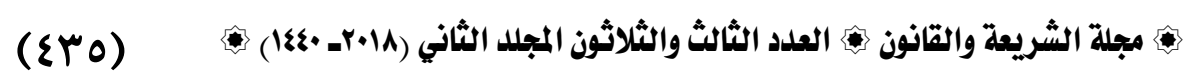

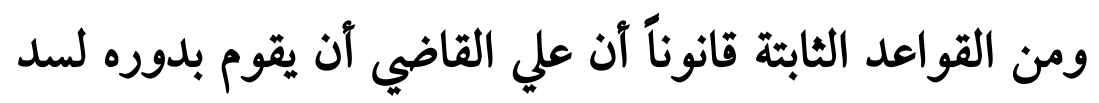

هذا الفراغ،وإلا كانت النتيجة وجود مسائل إجرائية،تثثل مشكلة إندانة

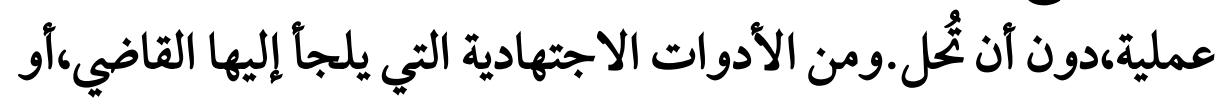

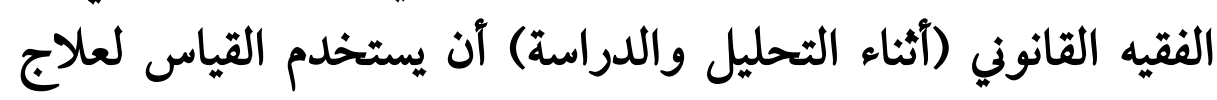

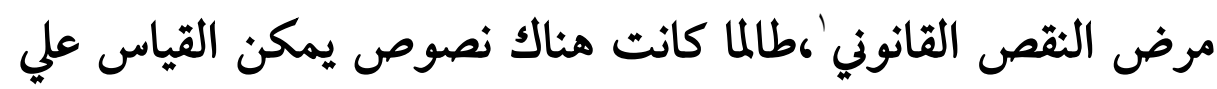

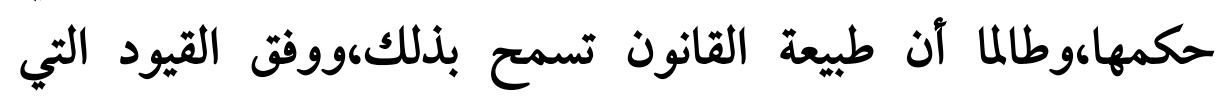
سنوردها علي شروط القياس الاجرائي.

فسكوت المشرع عن إيراد قاعدة قانونية تحكم القضية (سكوتاً

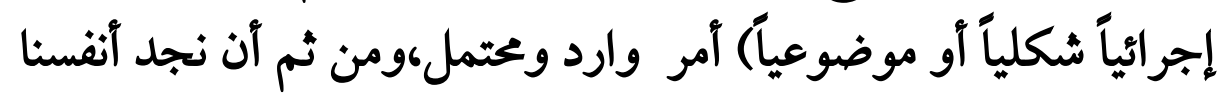

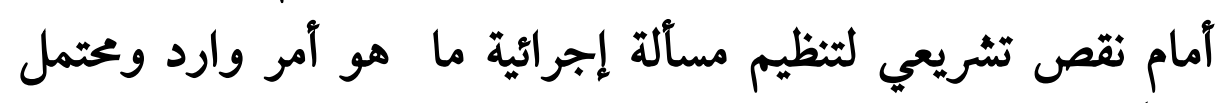

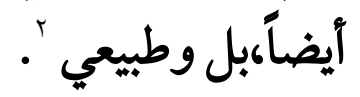

1 ـ والقاضي في هذه الحالة وإن كان يقوم بخلق قاعدة قانونية تُطبق في القضية

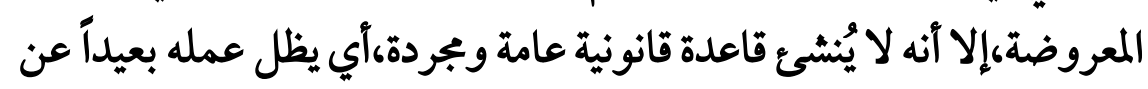

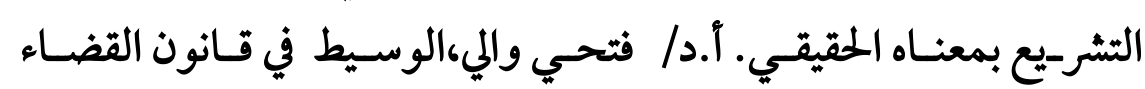

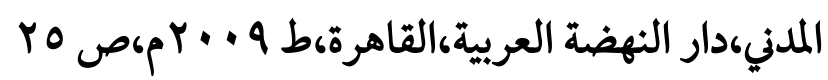

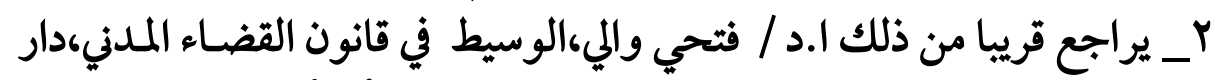

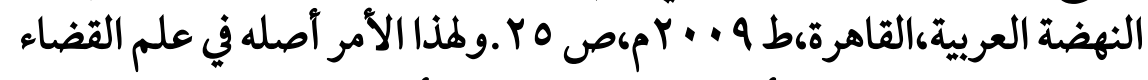

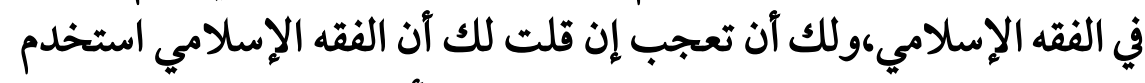

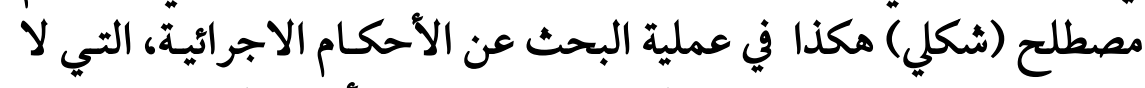

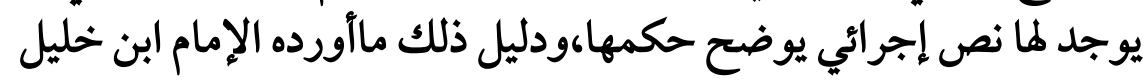

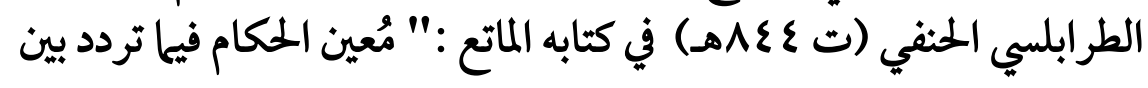




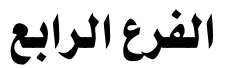

أركان القياس وفقاً لمعناه في الفقه الإسلامي

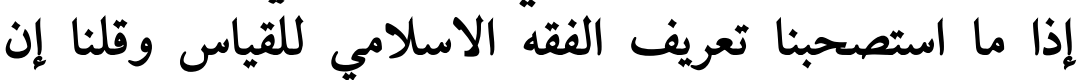

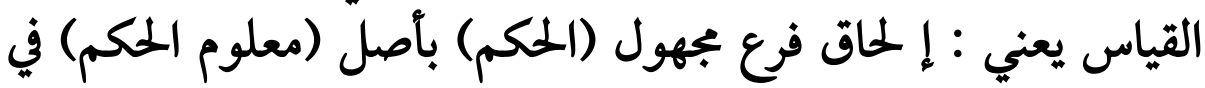

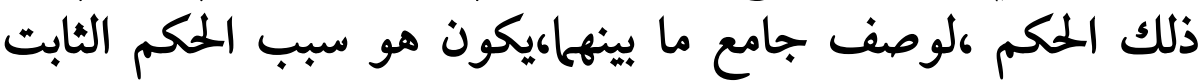

للأصل، مع انتفاء الفارق بين الأصل .....

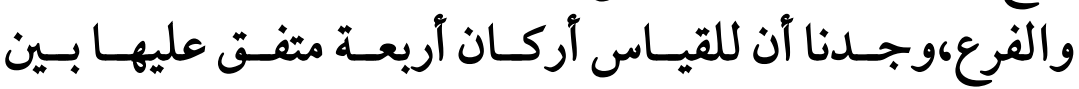

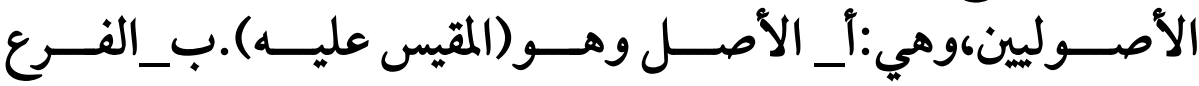

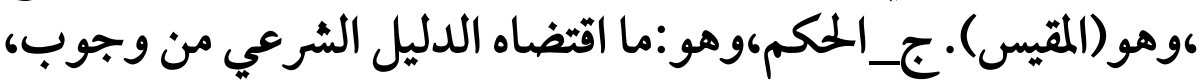

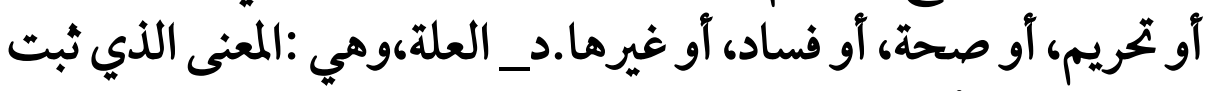

المطلب الثاني

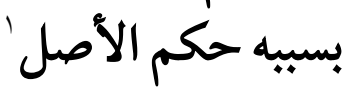

الخصمين من الأحكام" ،بسنده عـن سـيدنا عمـر رضي الله عنه،بخصـوص

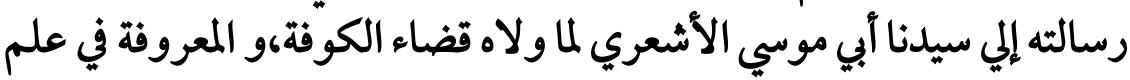

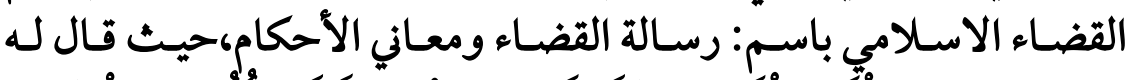

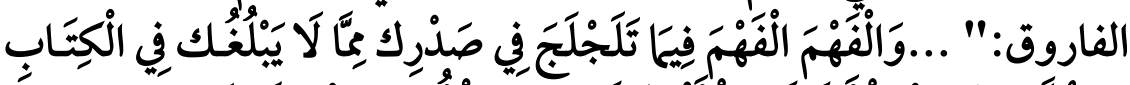

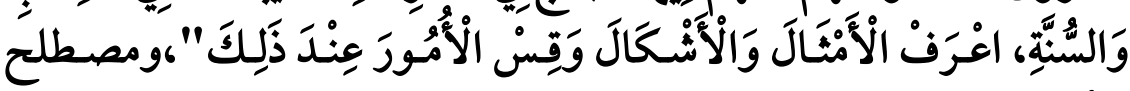

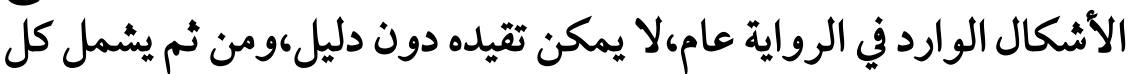

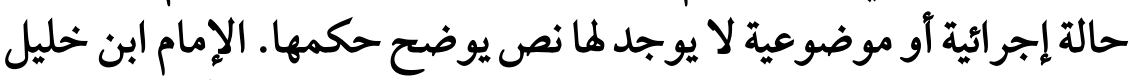

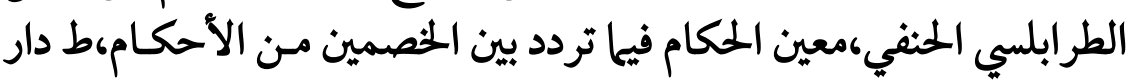

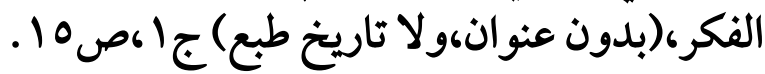

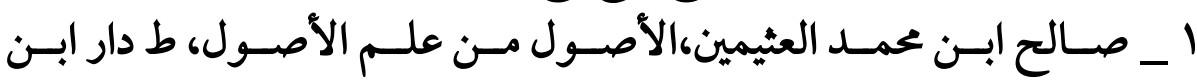

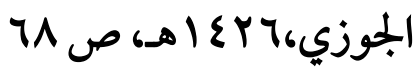




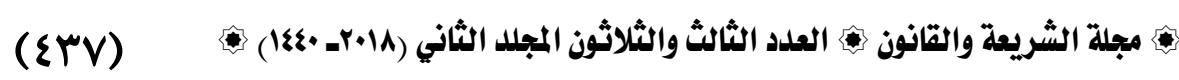

\section{موقف الفقه الاجرائي والقضاك من العمل بالقياس بذات معناه}

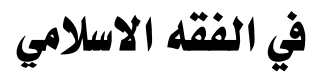

بعد أن أوضحنا بإيبـاز مفهوم القياس في اللغـة،وفي اصطلاح الاهي

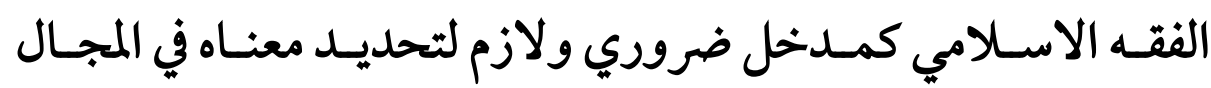

الاجرائي القانوني،بات السؤال الطبيعي ووفقاً للتسلسل المنطقي هـو :

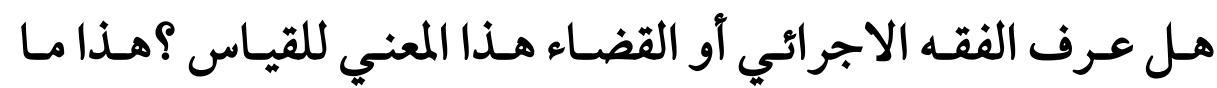

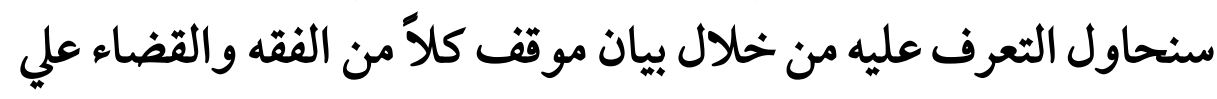
حده، وذلك علي النحو الآتي :

الفرع الأول

موقف الفقه الاجرائي من مصرفة القياس بمعناه

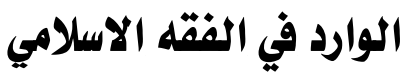

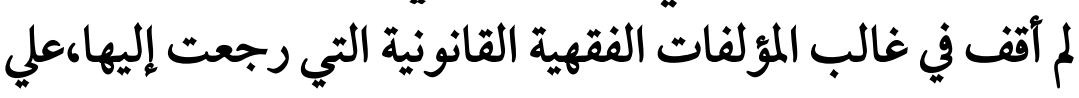
تناول معني القياس بذات المعني الذي آثار إليه السادة العلماء في الفقه الفهاتيه

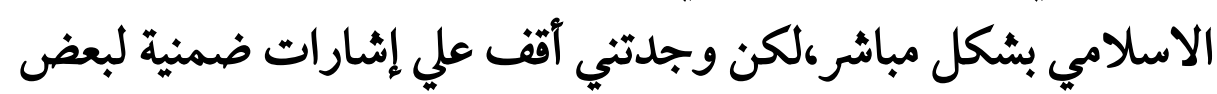

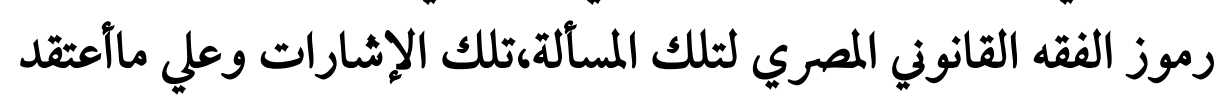

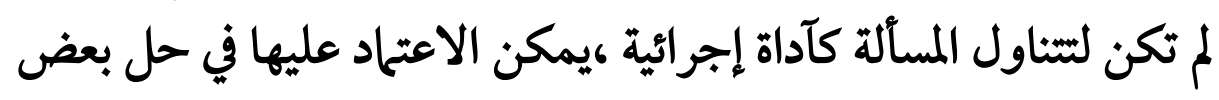

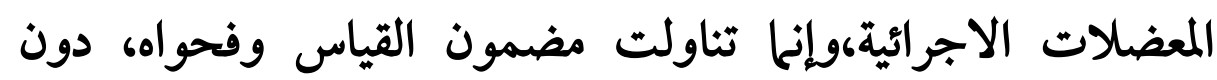
التصريح بلفظة القياس، وذلك بصدد حديثها عن النقص الاجرائي في تنظيم بعض المسائل الاجرائية. بل كان من اللافت للانتباه أنه وأثناء

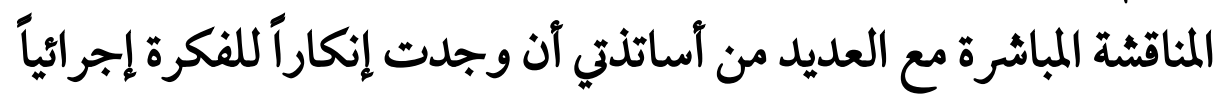


'،وهو ماكان أحد الأسباب المهمة التي أبتت داخلي إصراراً قوياً علي

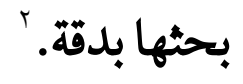

1 ـ _ ولا ضير في ذلك، إذ أن اعتبار القياس دليلاً من أدلة الأحكام الشرعية أصلاً

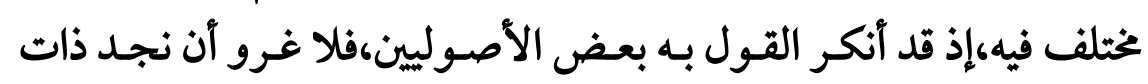

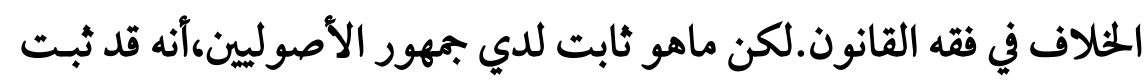

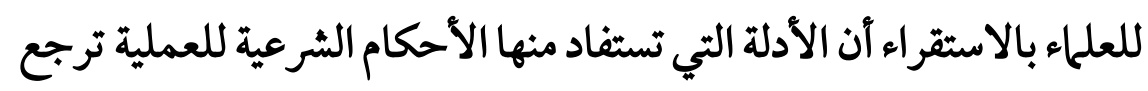

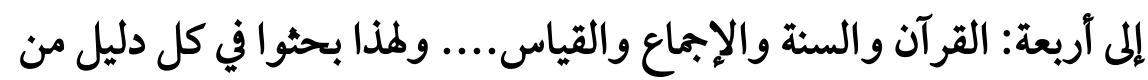

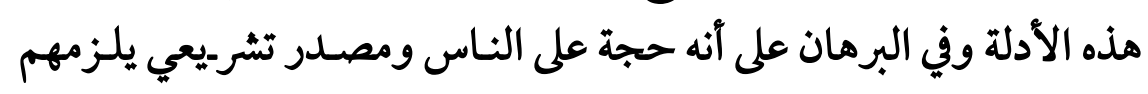

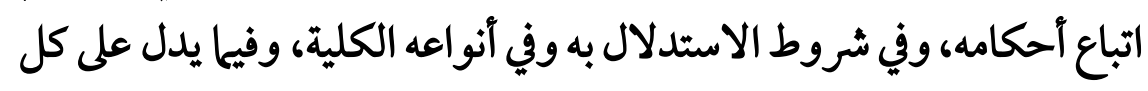

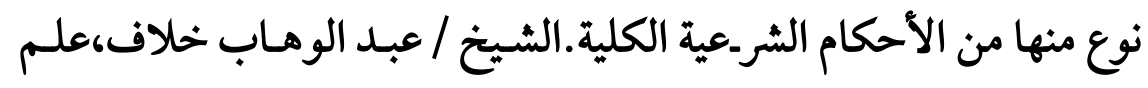

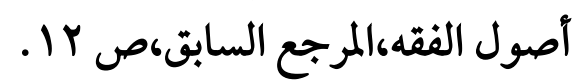

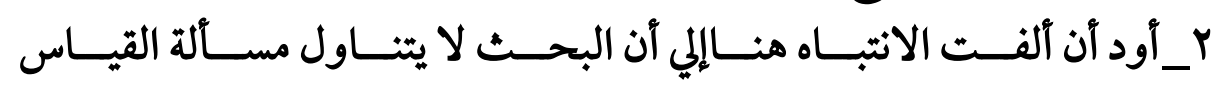

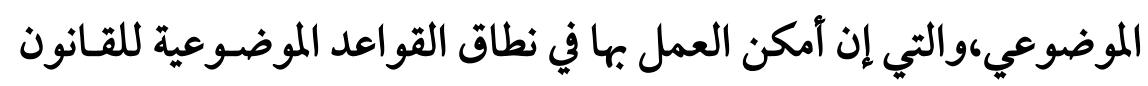

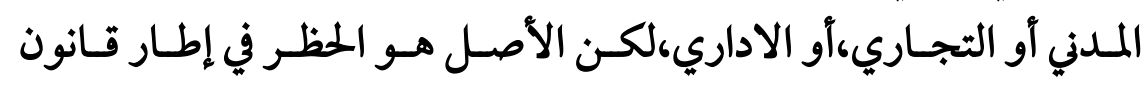

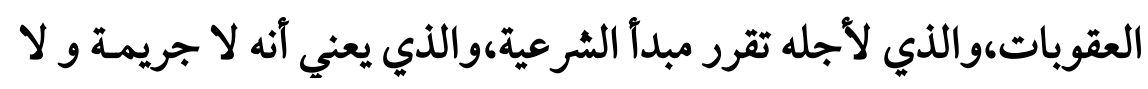

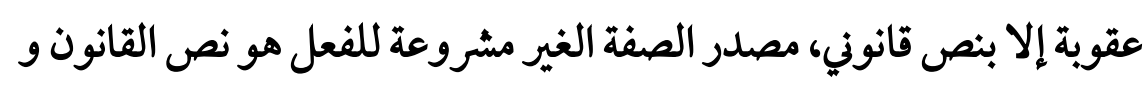

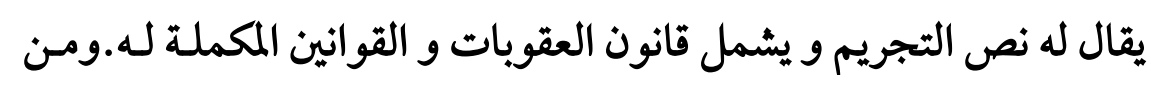

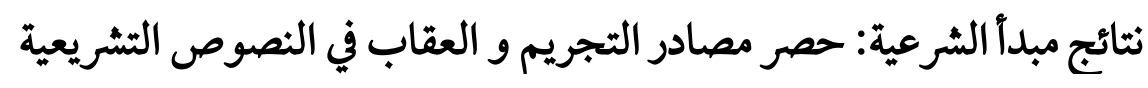

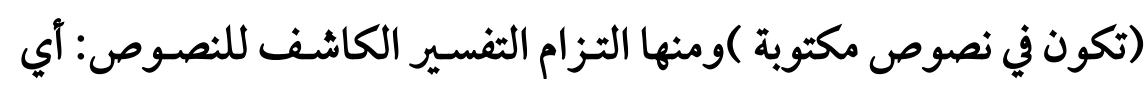

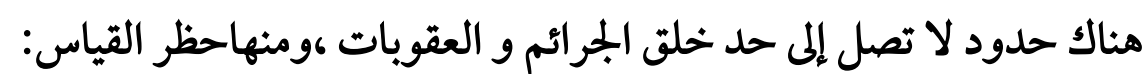
حيث تنحصر مهمة القاضي في تطبيق القانون لا خلق الجرائم، الماتوترجع أهمية 


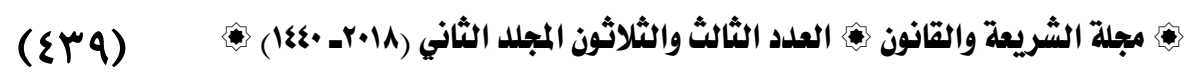

أما عن التناول الضمني لبعض الفقه المصري لمسألة القياس،فأود

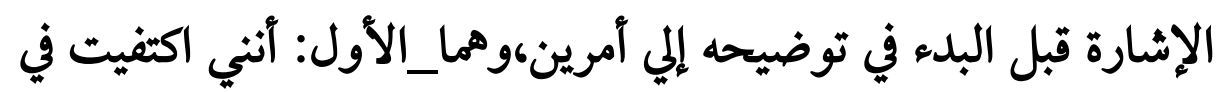

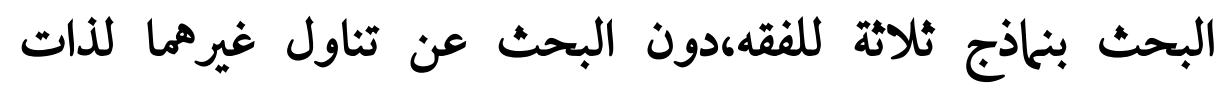
المسألة،لكون ذلك كافياً لاثبات وجود المسألة في فكر الفقه القانوني ولو فئو بشكل غير صريح.الأمر الثاني:هو طبيعة الدراسة،والتي بذاتها تقتضي التركيز وعدم الاطناب،والاكتفاء بالفحص الدقيق للموضوع.

مبدأ الشرعية إلي أنهيعد من أسس الحرية الفردية و يضمن حقوق الأفراد

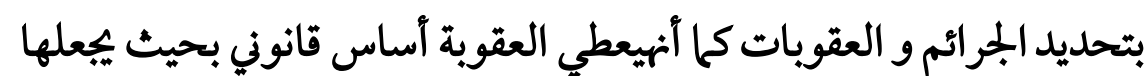

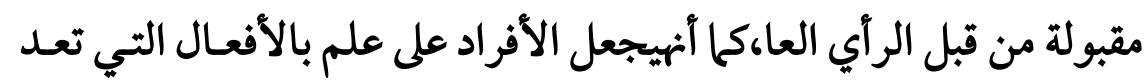

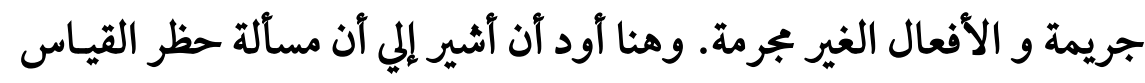

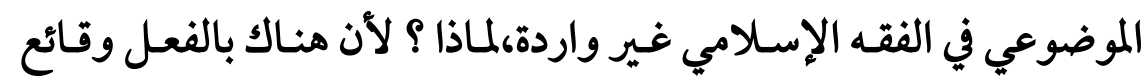

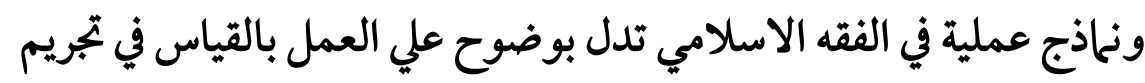

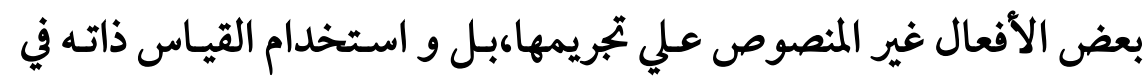

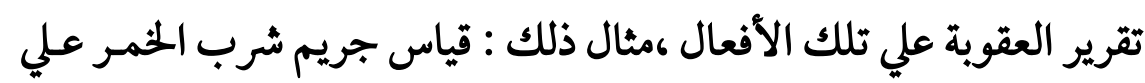

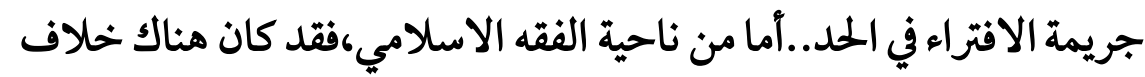

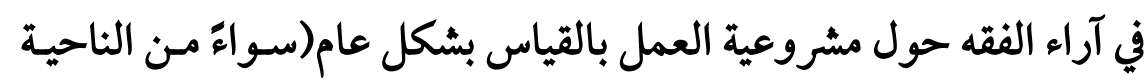

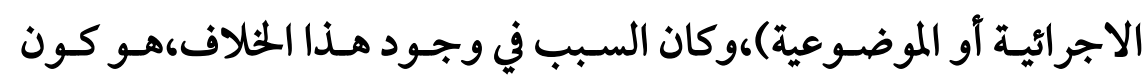

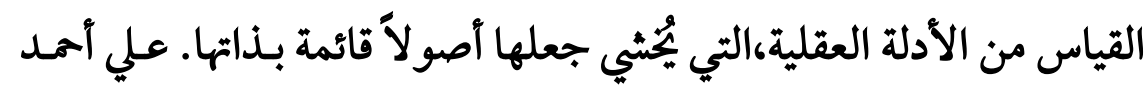

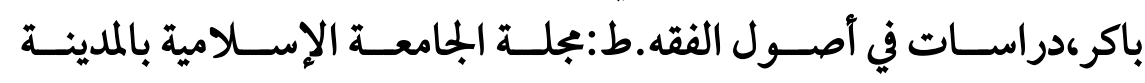

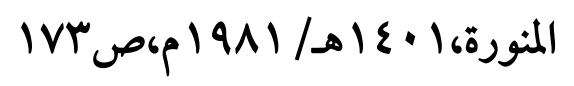


أما عن الناذج الثلاثة للفقهالتي أشارت بشكل غير صريح

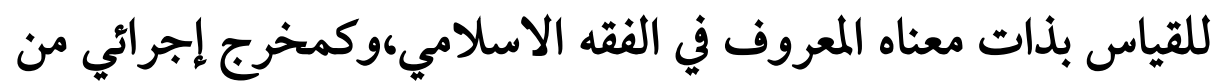
بعض الصعاب الاجرائية،في علي النحو الآتي :

$$
\text { النموذج الأول: - الائل }
$$

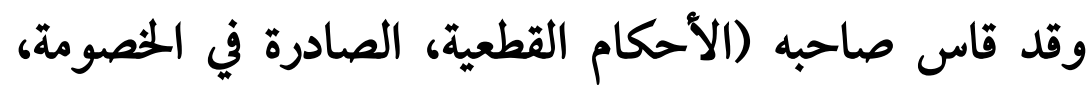

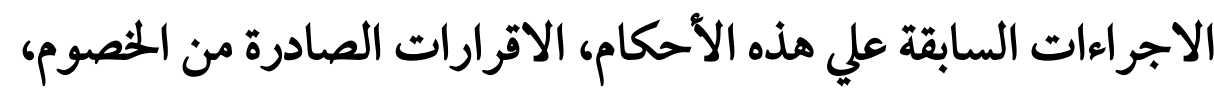

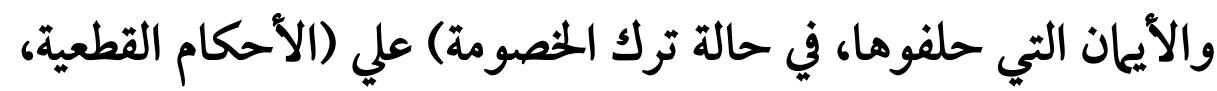

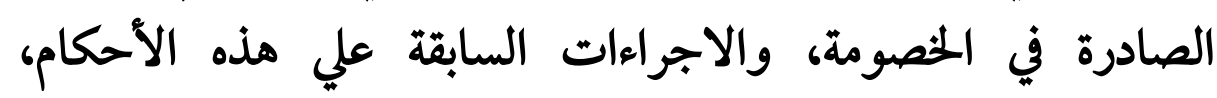

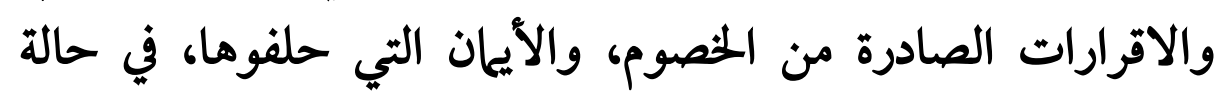

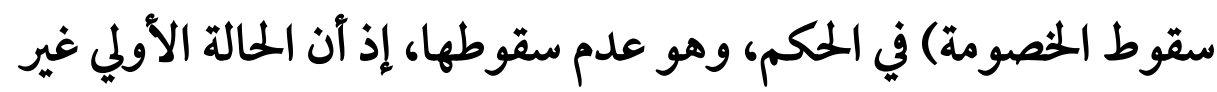

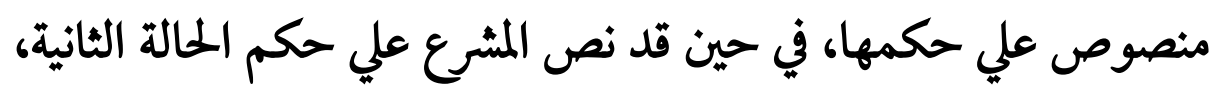

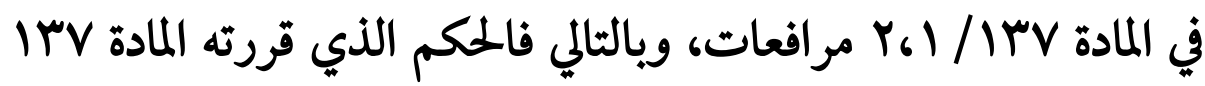

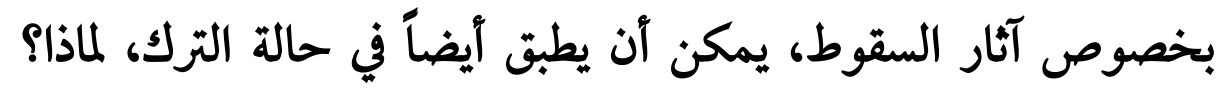

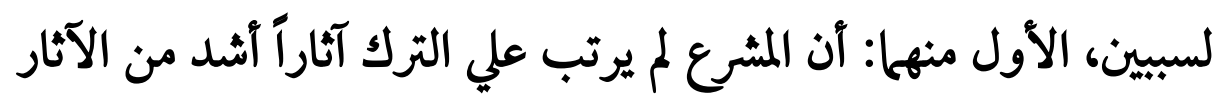

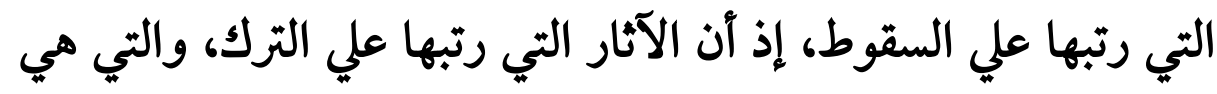

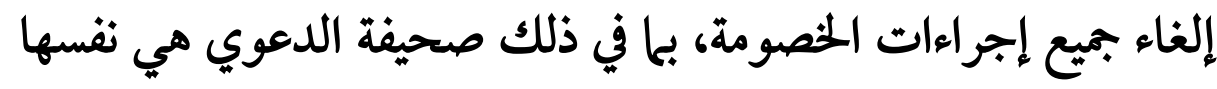

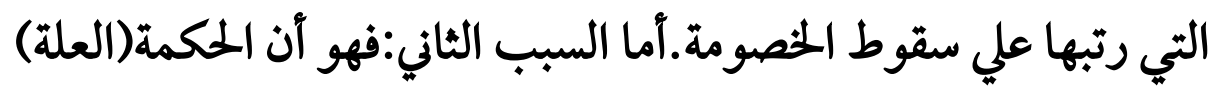

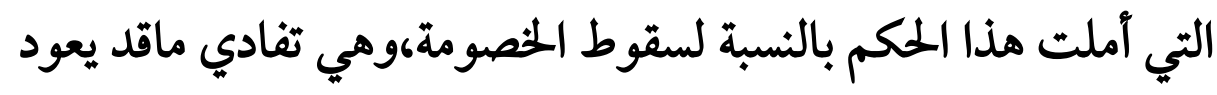

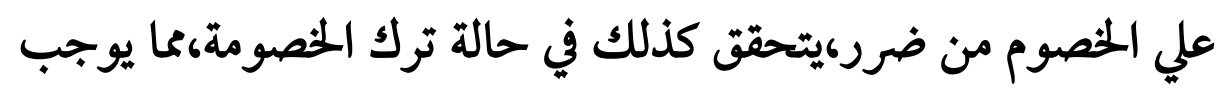


تطبيقه أيضاً في هذه الحالة، مادام لا يوجد في النصوص الواردة في باب ترك الخصومة مايمنع تطبيقه' .

1 آ.د/ آحمد عوض هندي،قانون المرافعات المدنية والتجارية،ط دار الجامعة

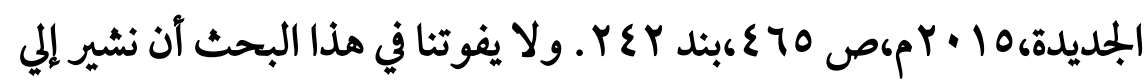

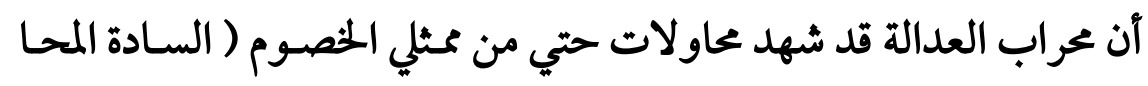

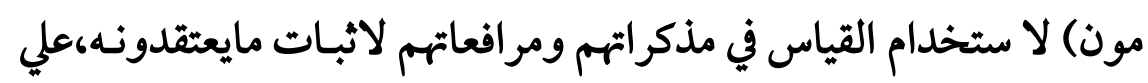

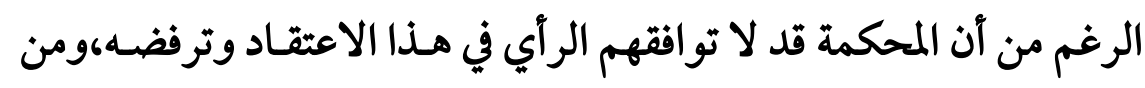

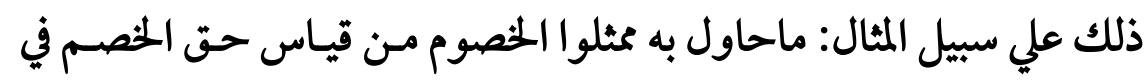

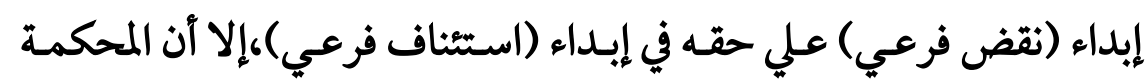

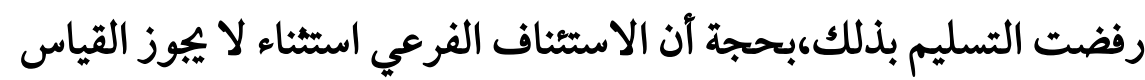

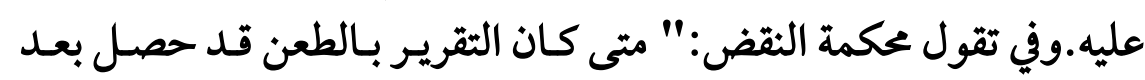

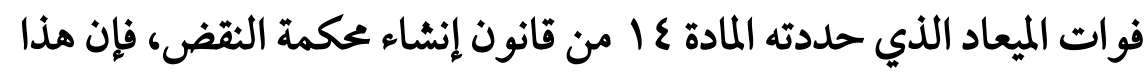

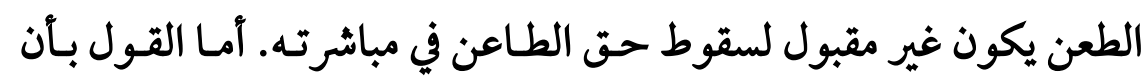

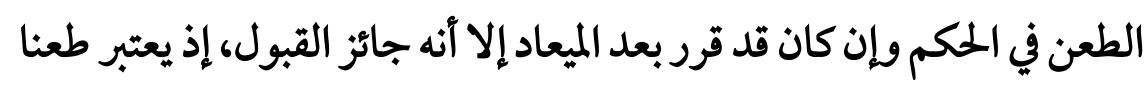

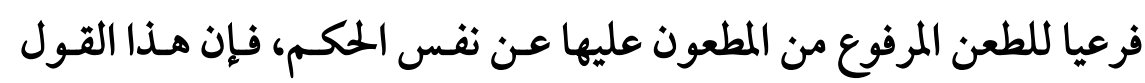

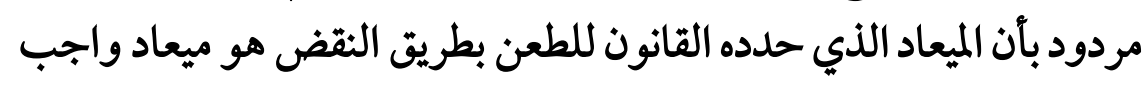

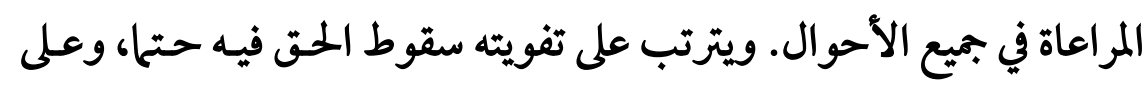

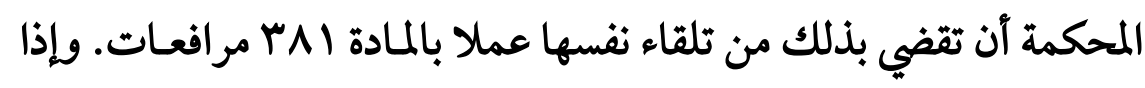

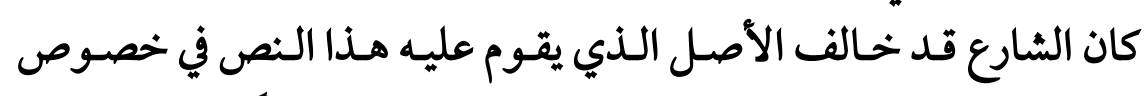
الاستئنف الفرعي إذ أجاز للمستأنف عليه أن يرفع استئنافاً فرعيا بعد مضي فئي

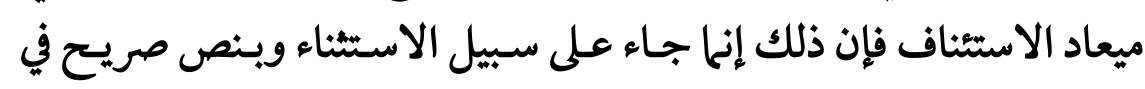


إذا مااستصحبنا مفهوم القياس الاجرائي الذي آشرنا إليه

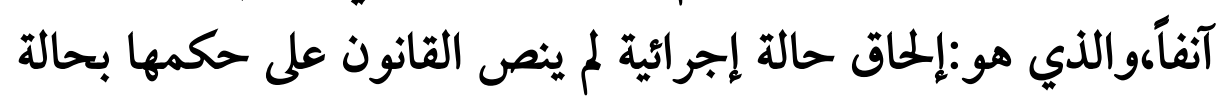

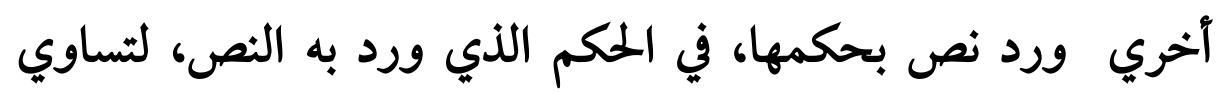

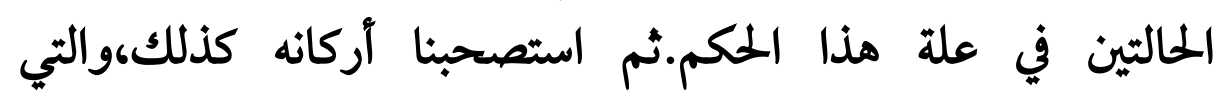
هي:(الأصل_الفرع_حكم الأصل_العلة)،ثم آثزلنا مفهوم القياس

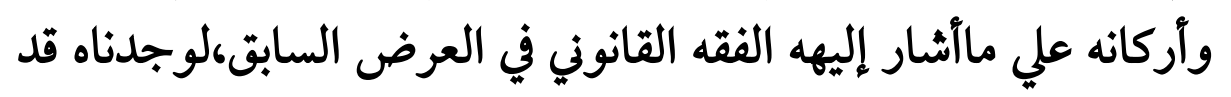

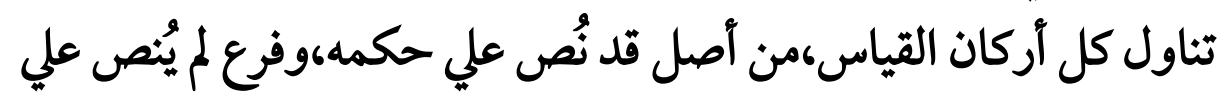

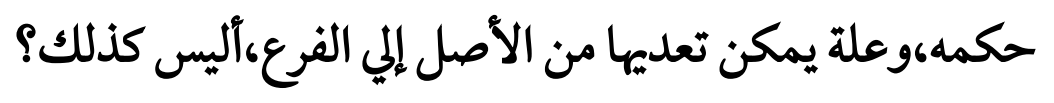

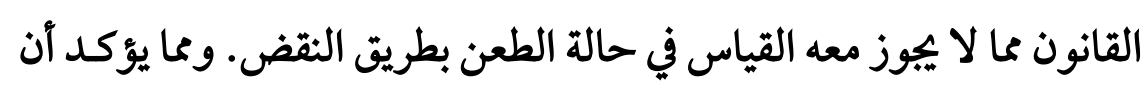

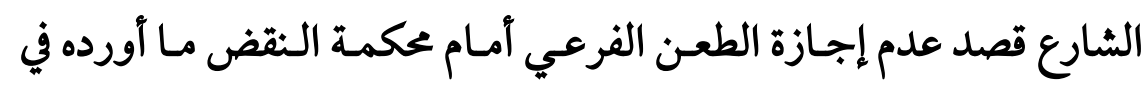

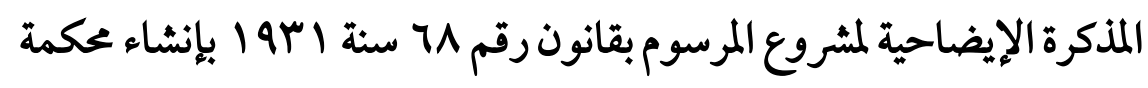

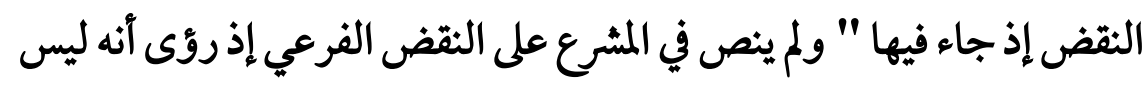

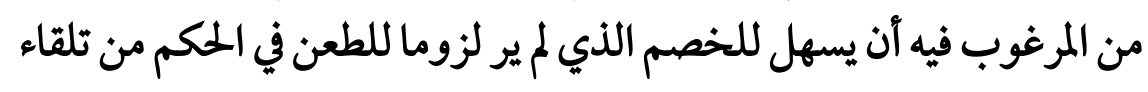

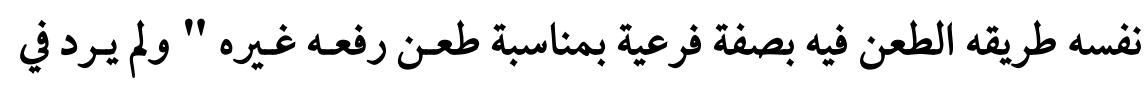

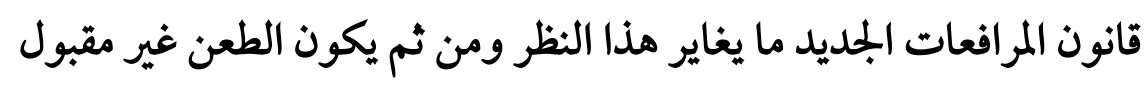

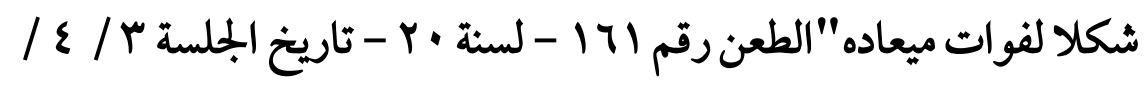

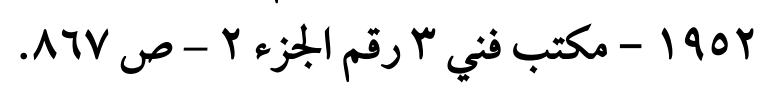


وقد ضرب لنا أصحابُه مثلاً واضحاً للقياس الاجرائي من قانون

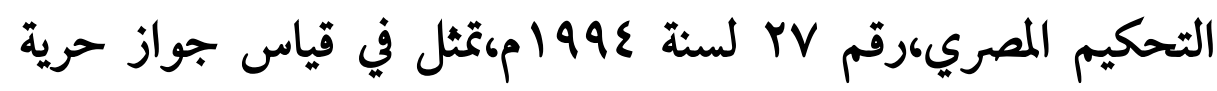
طرفي التحكيم في اختيار القانون واجب التطبيق علي اتفاق التحكيم(كفرع لم يُنص علي حكمه) علي حرية ذات الطرفين في اختيار

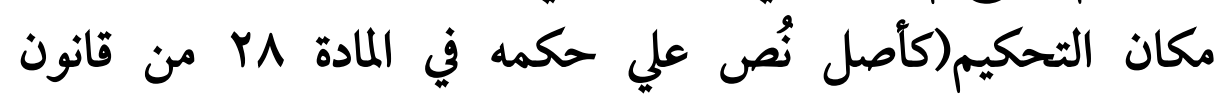
التحكيم)،لاشتراكها في ذات العلة،وهي تبسيط وتيسير عملية التحكيم

$$
\text { لإنهاء النزاع.' النموذج الثالث : }
$$

وقد ذكر أصحابه مثالا للقياس،تثل في قياس الإجراءات الشكلية التي يخضع لها الطعن المقابل بالتحاس إعادة النظر(كفرع فقهي

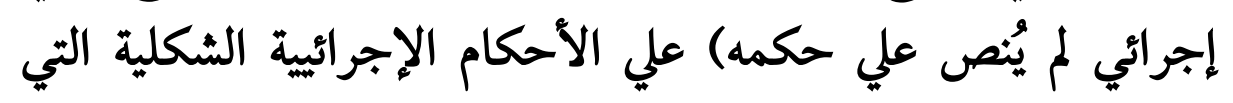

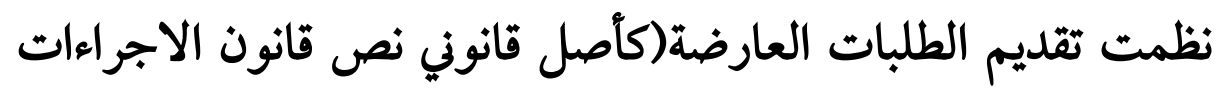

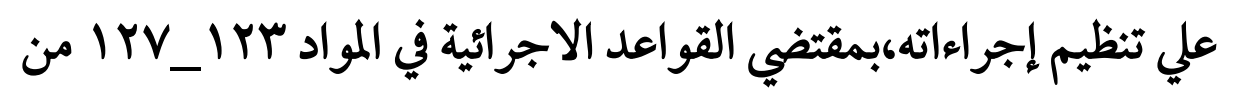

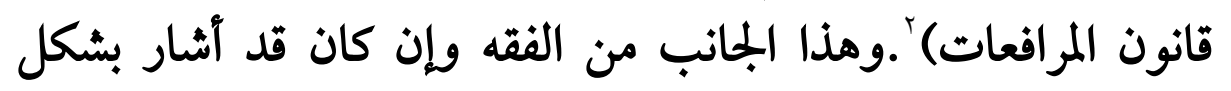

1_ آ.د/ مصطفي الجمال،وعكاثـة عبـد العـال،التحكيم في العلاقـات الخاصـة

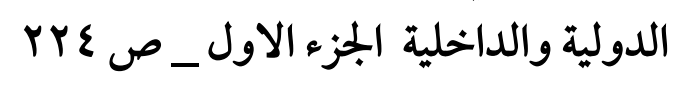

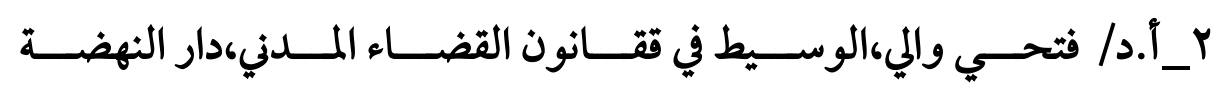

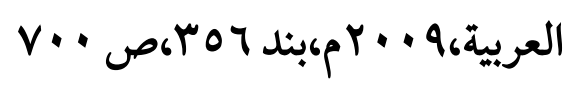




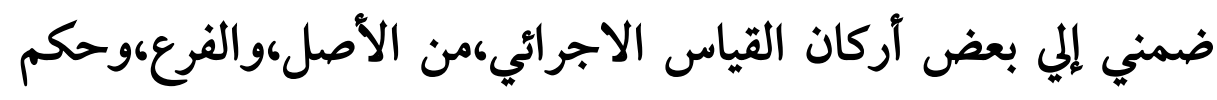

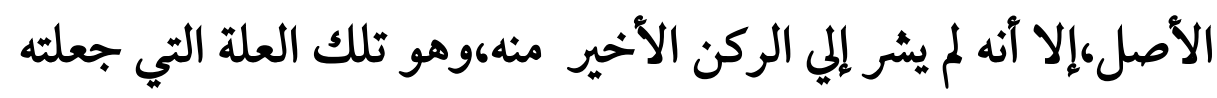
يقوم بهذا القياس.وفيا نعتقده أن هذه العلة تكمن فيب كون كل الإيل منها يعد بمثابة طلب فرعي،مقابل للطلب الأصلي.

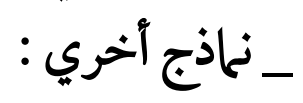

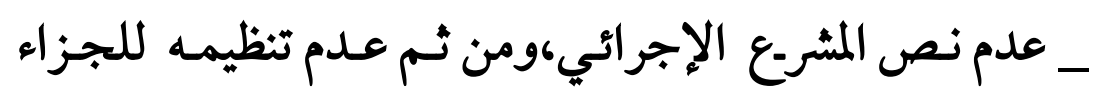

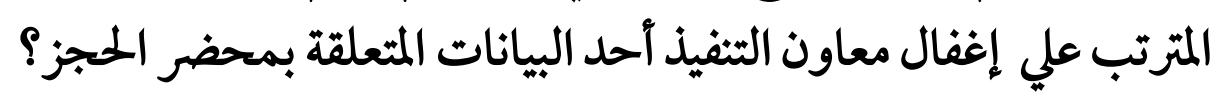

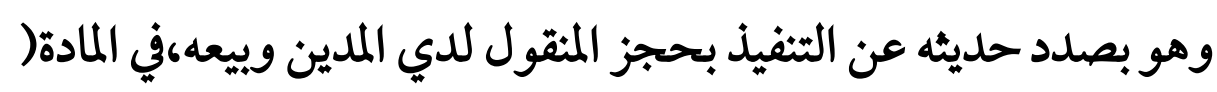

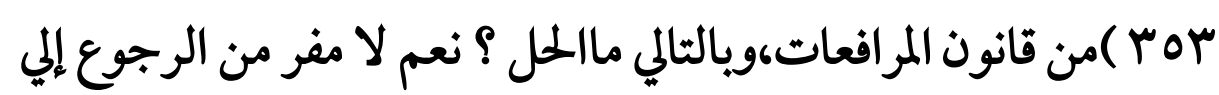

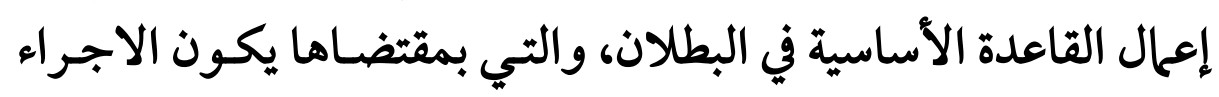

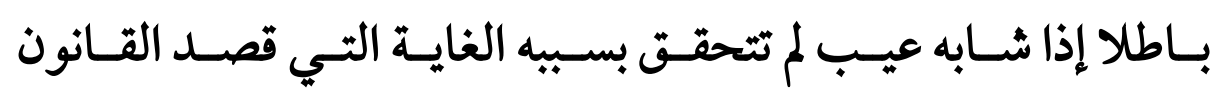

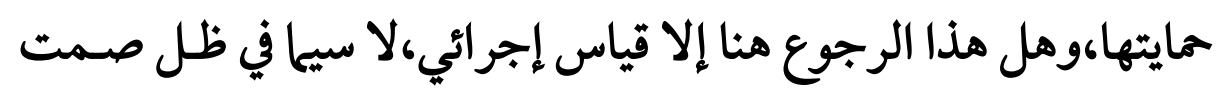

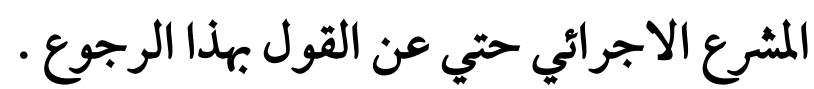

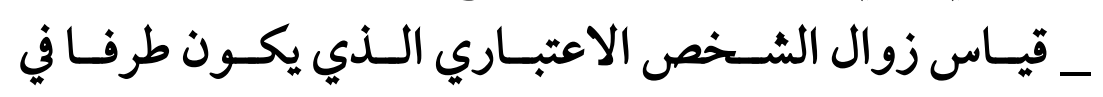
الخصومة(قضائية كانت أو تحكيمية) أثناء سيرها،كحل الشركة ألخاري أوديجها

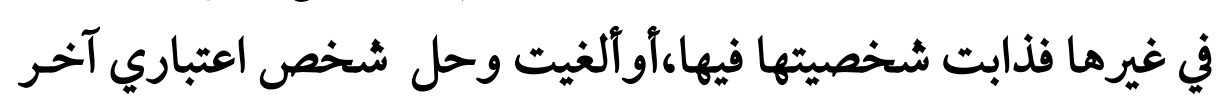

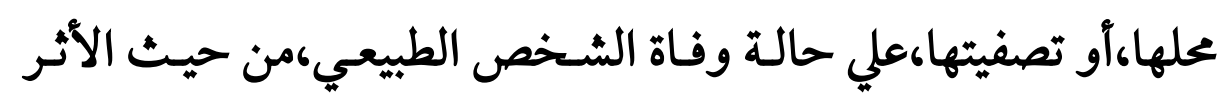

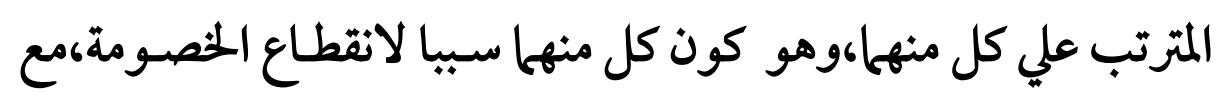
ملاحظة أن الن 


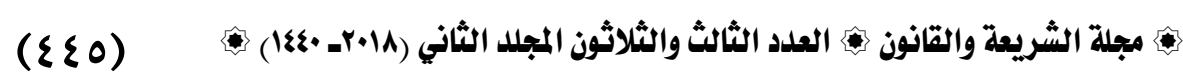
القـانون لم يعتـبر وفـاة المحــامي أو الوكيـل سـبـا مـن أسـباب

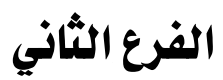

الانقطاع.

موقف القضاء المصري الاجرائي من العمل بالقياس بذات معناه الوارد في

\section{الفقله الاسلامي من العمل بالمئ}

إن السؤال الطبيعي في هذا البحث تجاه موقف القضـاء المصر-ي العباهي

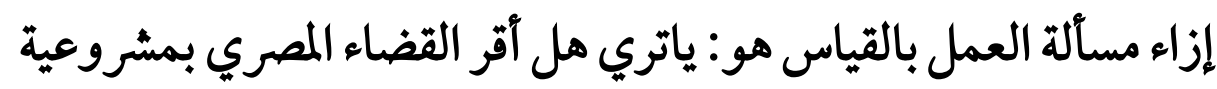

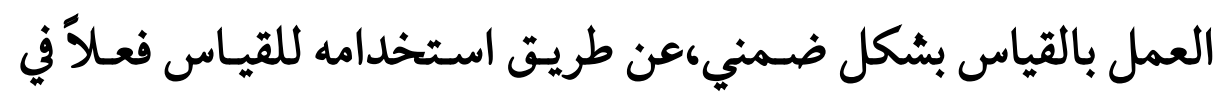

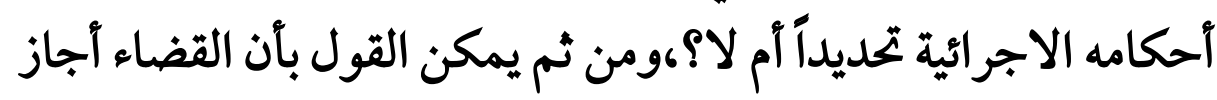

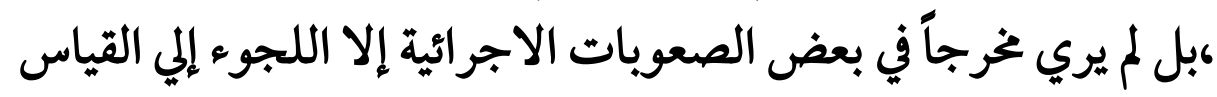

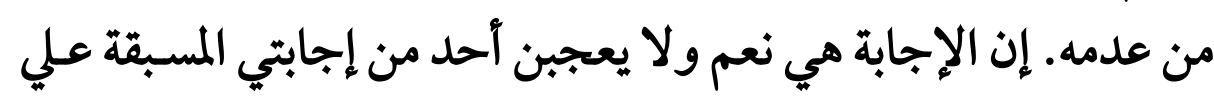
التساؤل قبل تحقيق وتحليل موقف القضاء،فقط لأن واقع الحال يقتضي-

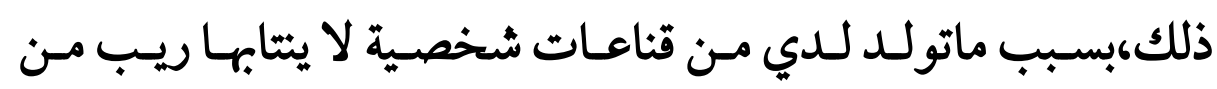

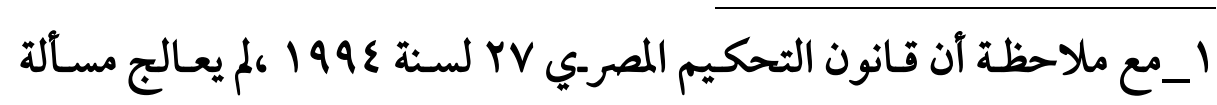

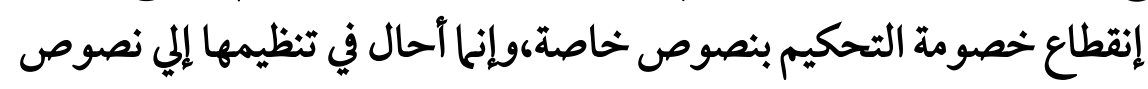

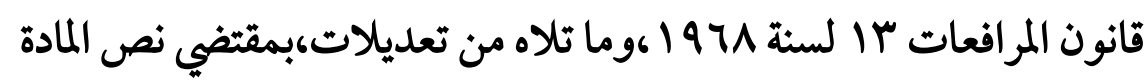
(YNA)

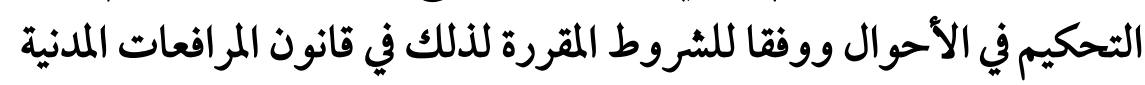

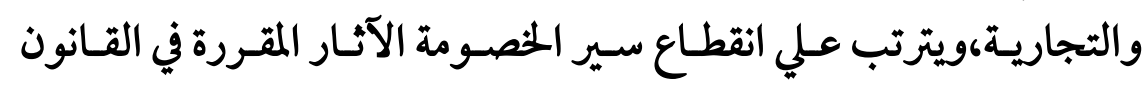
المذكور. 


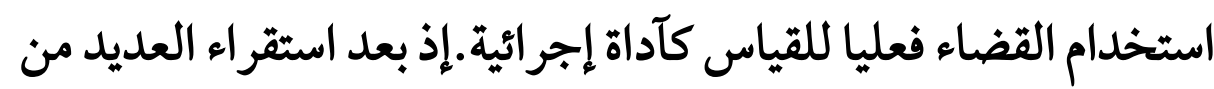

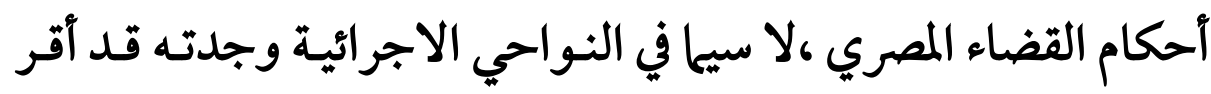

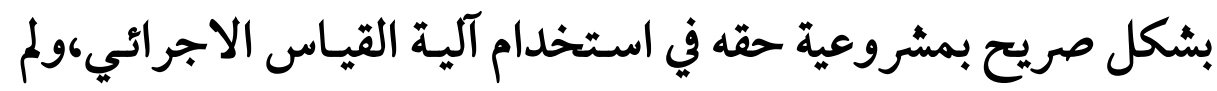

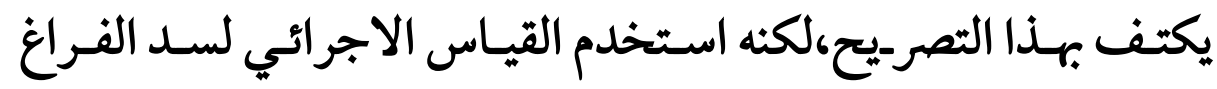

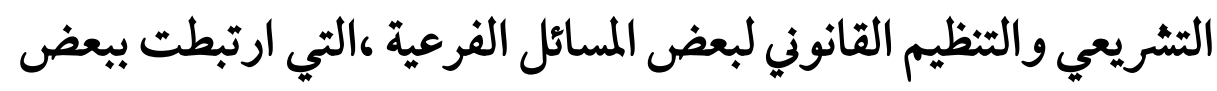
القضايا التي نظرها.

أما عن إقرار القضاء المصري بمشروعية العمل بالقياس

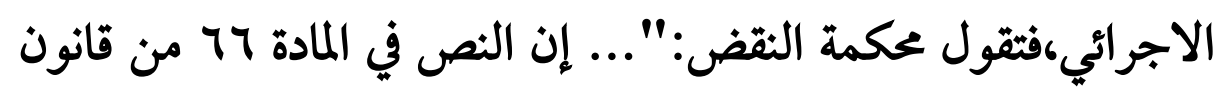

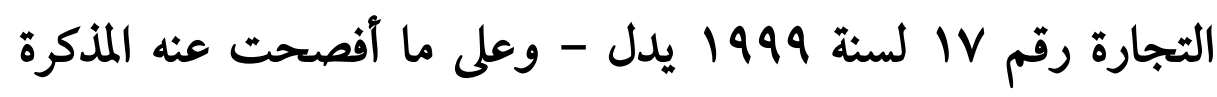

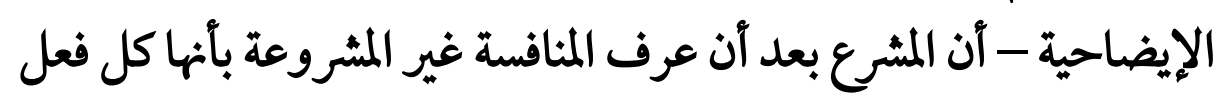

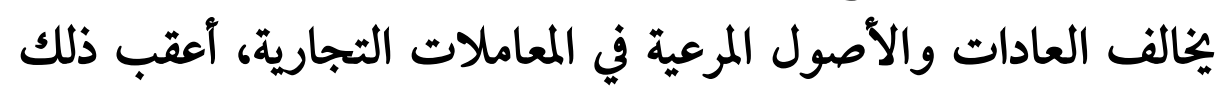

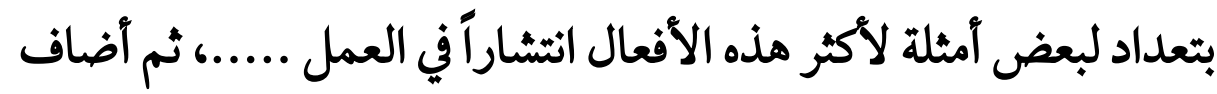

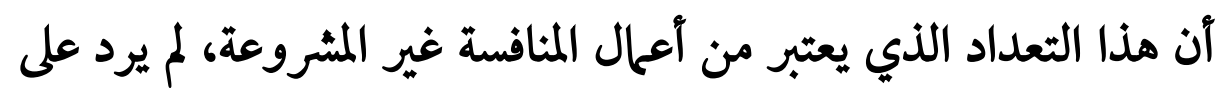

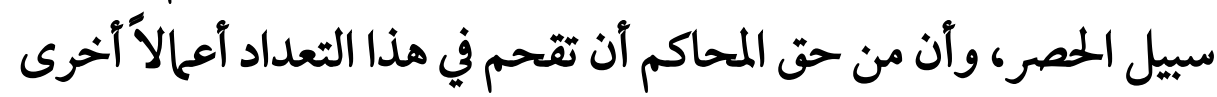

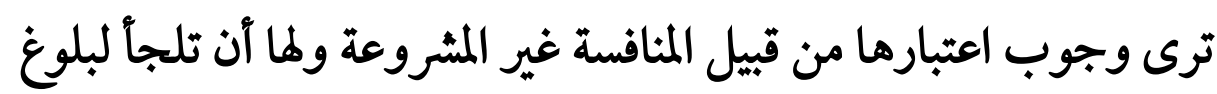

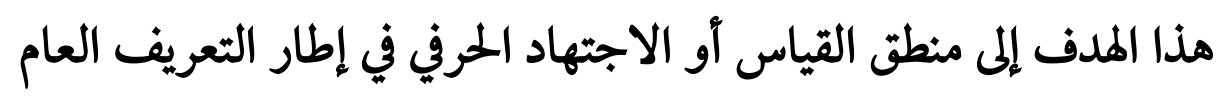

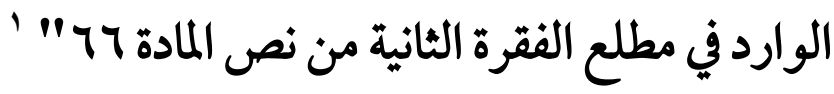

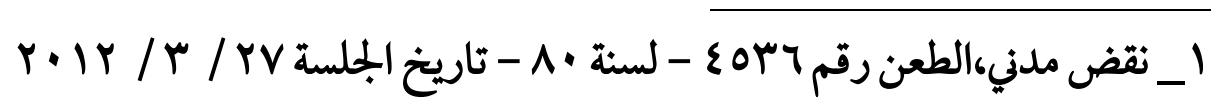

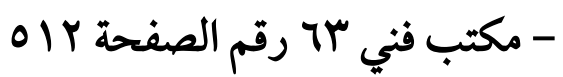




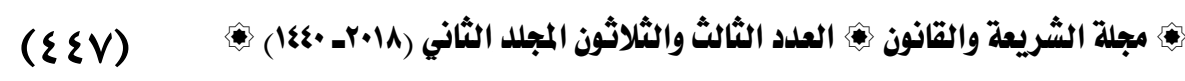

أما عن استخدام القضاء المصري للقياس الاجرائي بشكل

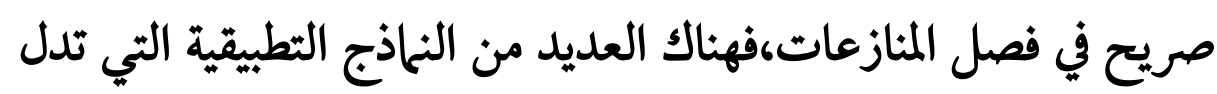
علي ذلك،ومنها علي سبيل المثال مايلي:

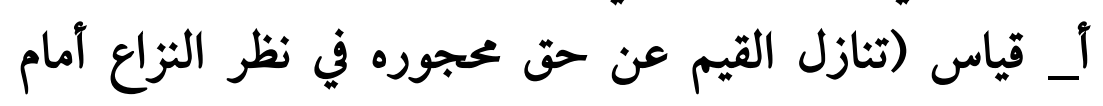
المحكمة المختصة) كفرع إجرائي لم ينص قانون ترتيب المجالس الحسبية الملغلي،قانون سنة 19Y0 ام علي حكمه علي (تصالح القيم) كأصل

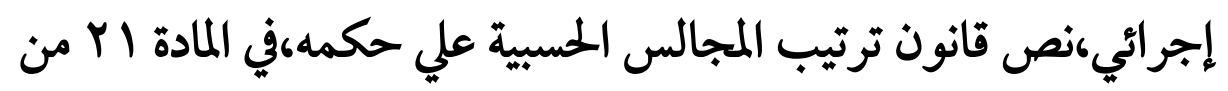

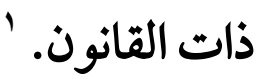

1 ـ وكانت هذه المادة تنص علي: ".. يجب على الأوصياء والقامة ووكلاء الغائين

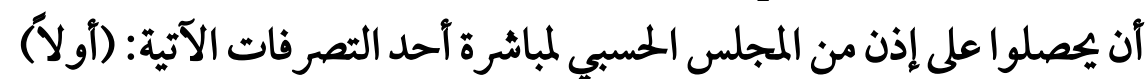

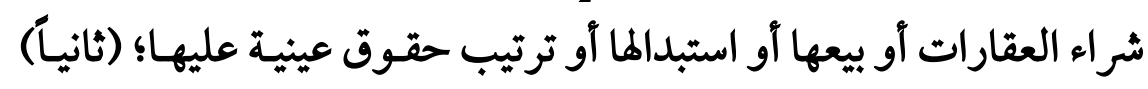

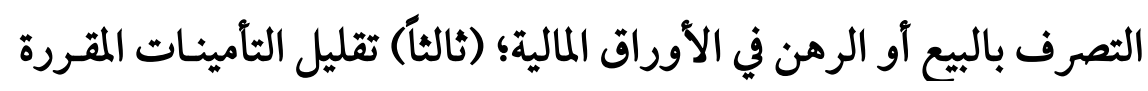

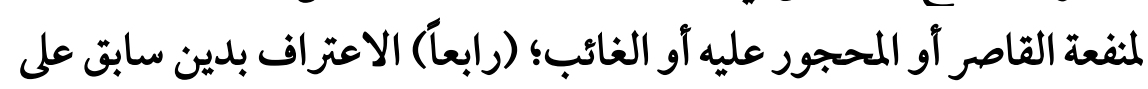

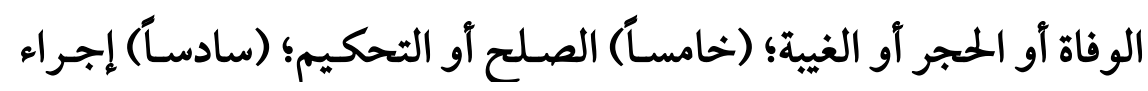

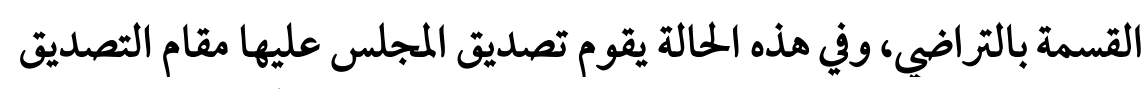

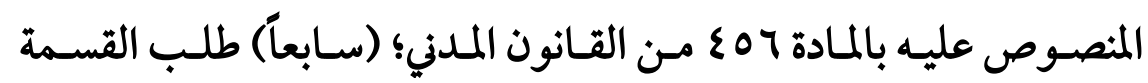

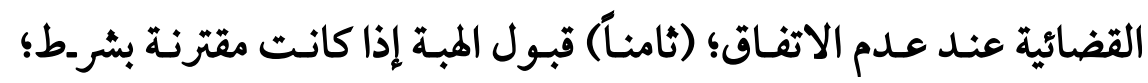

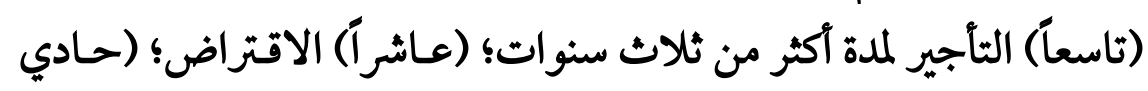

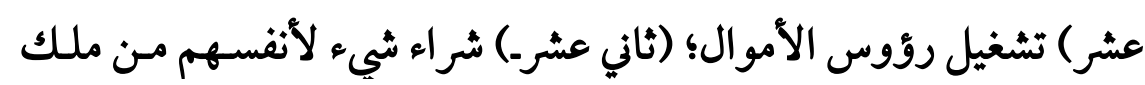

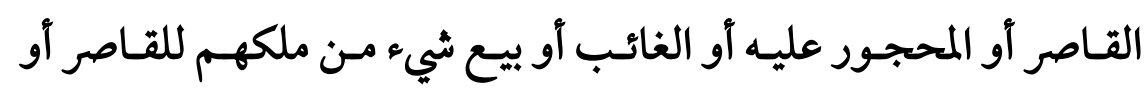


إذ منعت المادة إ من قانون ترتيب المجالس الحسبية القيم من

إجراء العديد من التصرفات القانونية،عددتها بشكل حصري،مئها

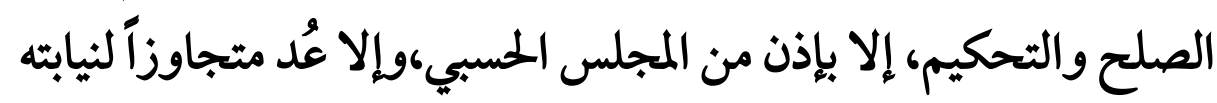

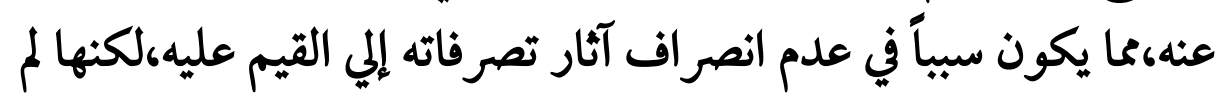

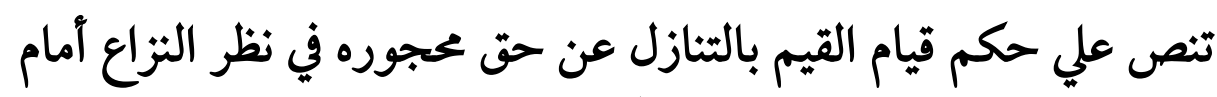

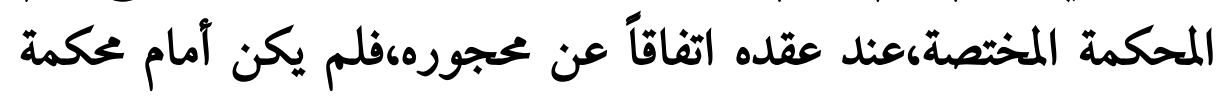

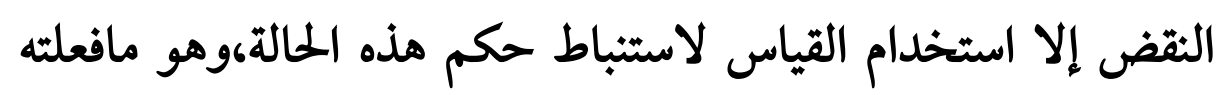

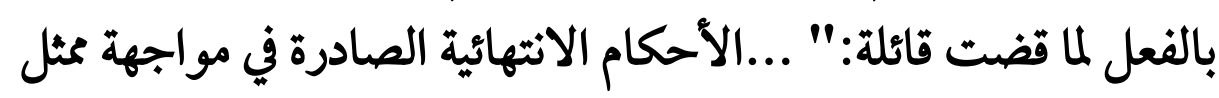

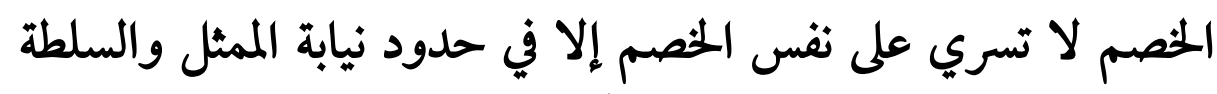

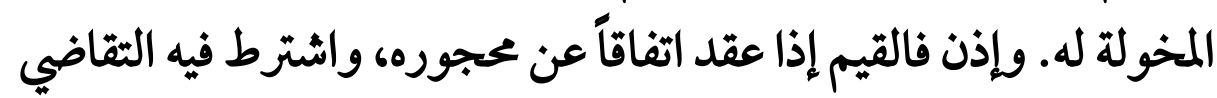

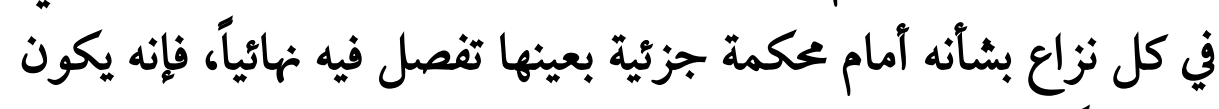

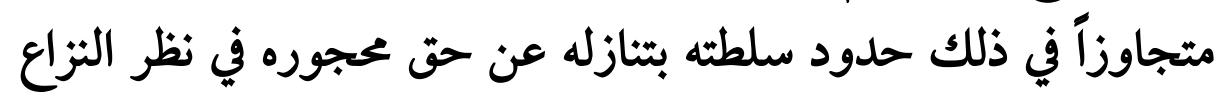

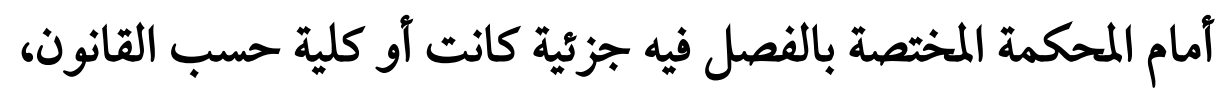

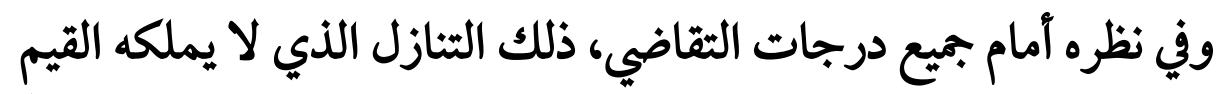

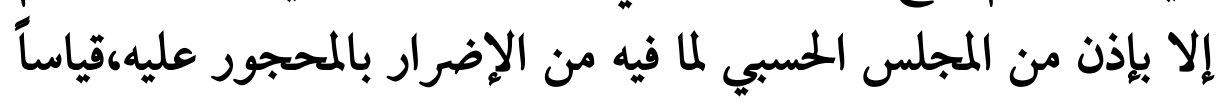

المحجور عليه أو الغائب؛ (ثالث عشر) استئجار ملك القاصر أو المحجور

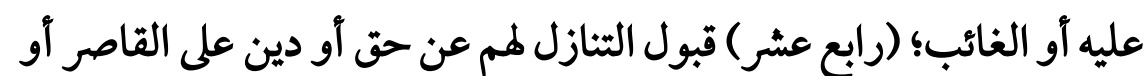

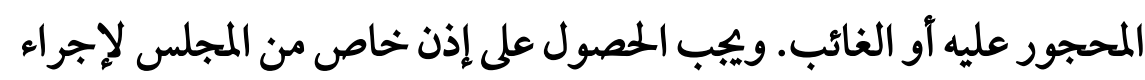

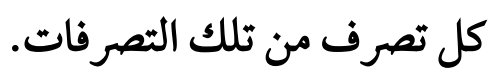


على الصلح الذي أوجب القانون صراحة في المادة إ من قانون المجالس المال

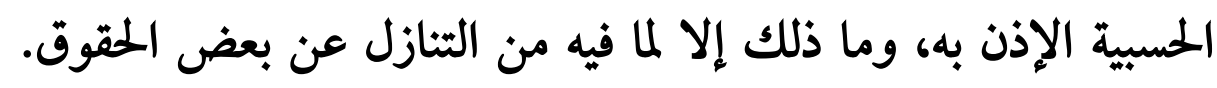

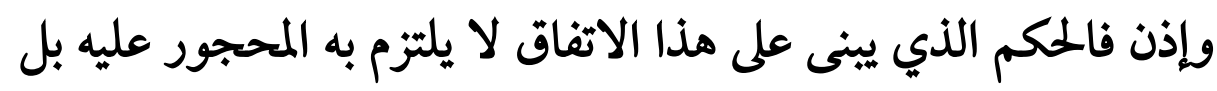

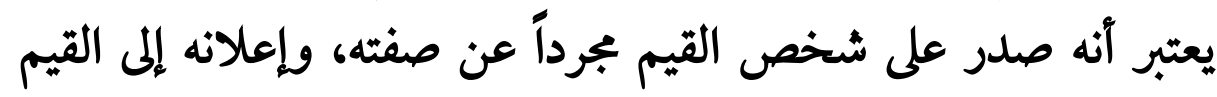

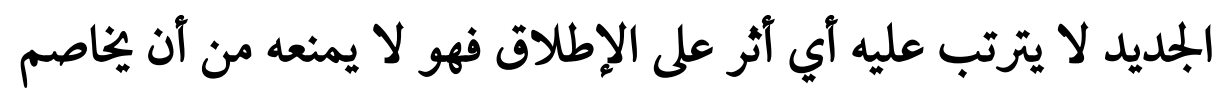

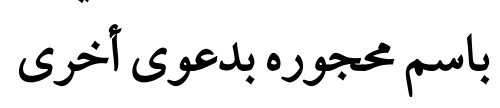

ب_القياس الاجرائي المتعلق بجواز رد عضو هيئة المفوضين بمجلس الدولة،ووجوب تنحيه (كفرع إجرائي لمُينص علي حكمه ) علي الميان جواز رد عضو النيابة،ووجوب تنحيه (كأصل نص القانون الاجرائي

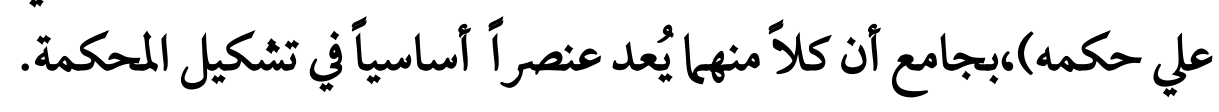
وفي إبداء الرأي القانوني المحايد فيها ، سواء في المذكرات التي تقدمهآ

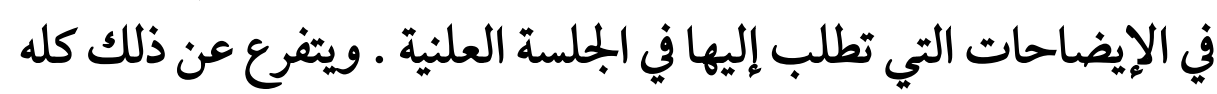

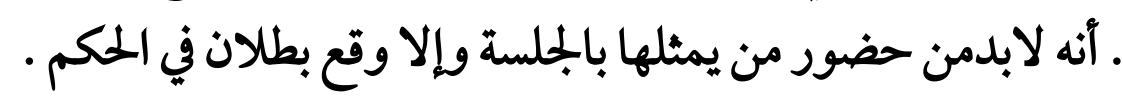

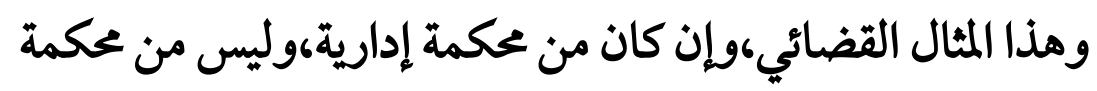

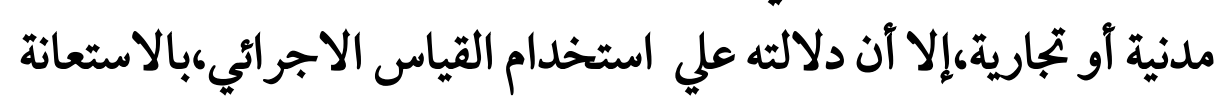

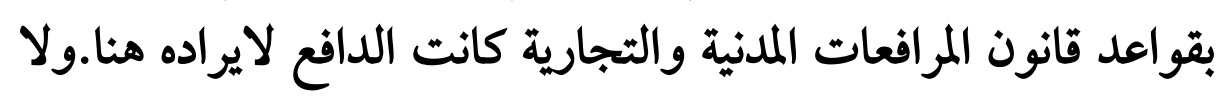
ريب فيا بين القوانين واستعانة القضاء بها من وشائج.

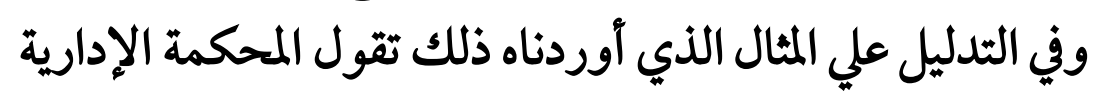

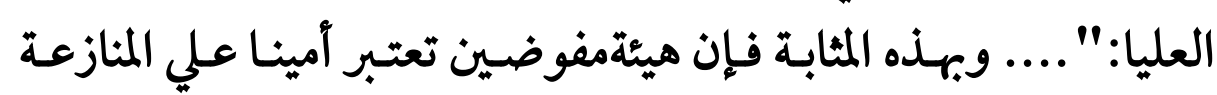


الإدارية ، وعاملا أساسيا في تحضيرها وتهيئة المرافعة ، وفي إبـاء الرأي

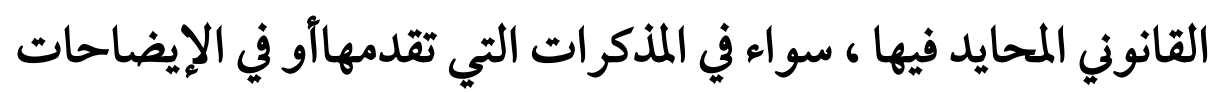

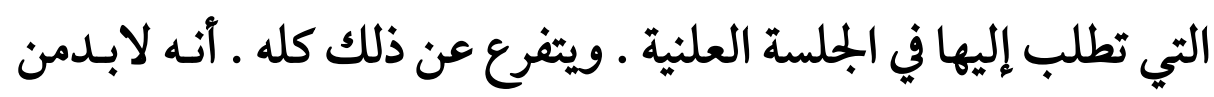

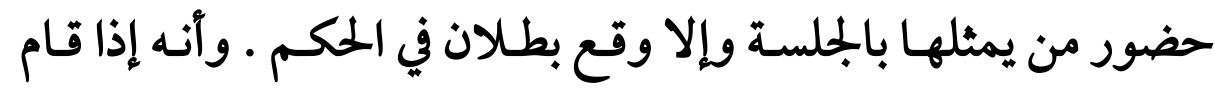

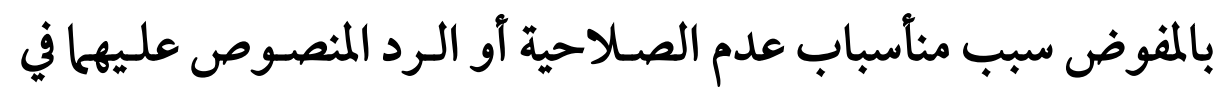

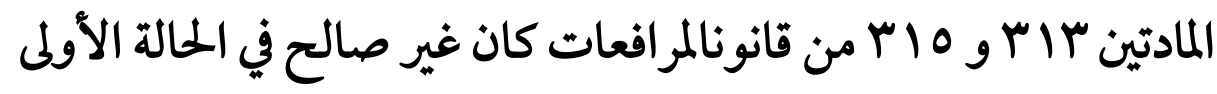
كمنوعا عن مباشرة مهمته في الدعوى وجازرده إن لم يتنح عنها في الحالة

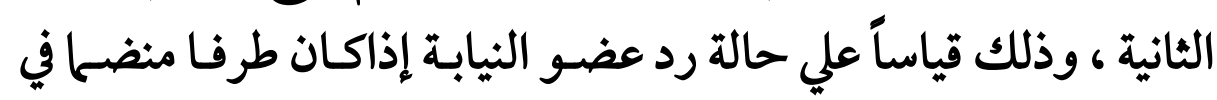

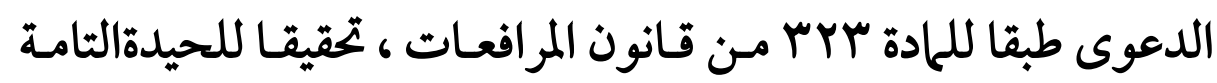

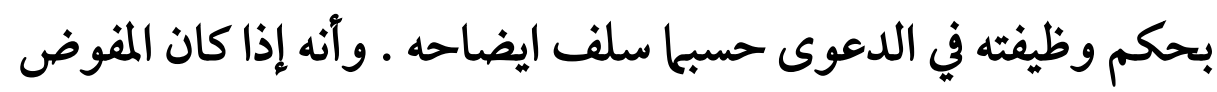

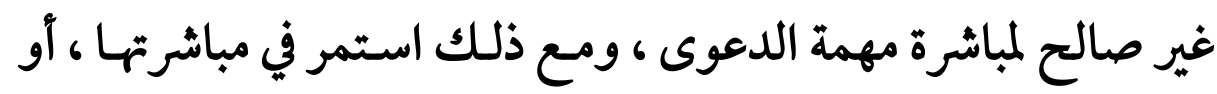

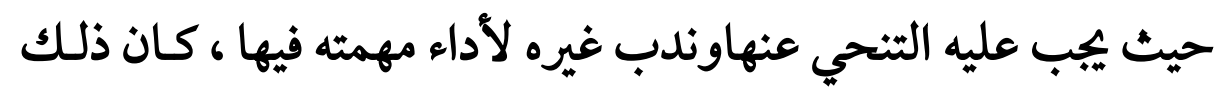
منطويا على بطلان في الإجراءات يؤثر في حكمفيعيبه ويبطله ، فإذا كان

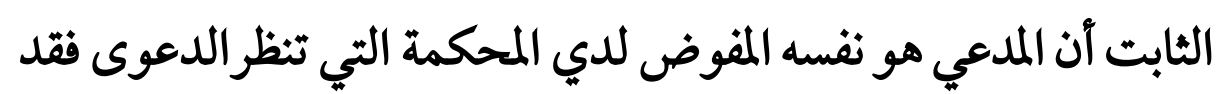

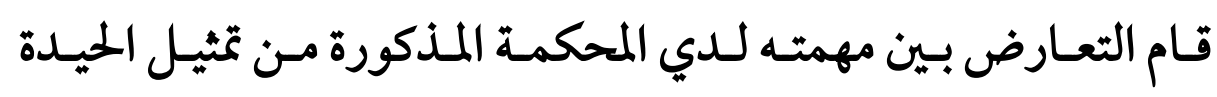

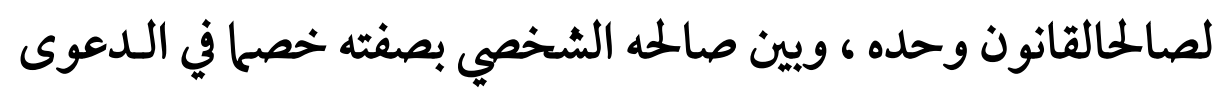

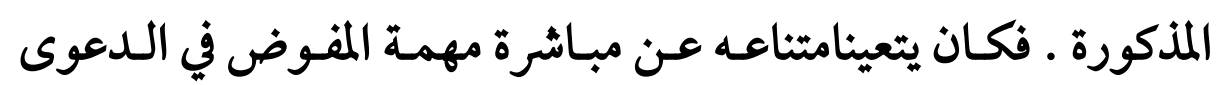




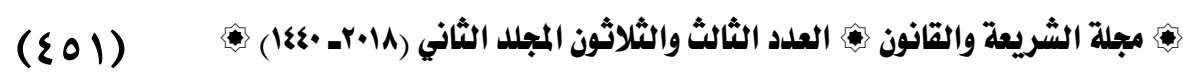

وندب غيره لذلك ولتمثيل الميئة بالمجلس ، أما أنه لم يفعل فيكون هـذا

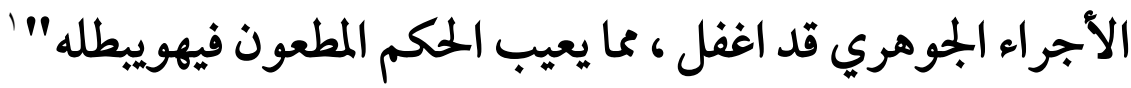

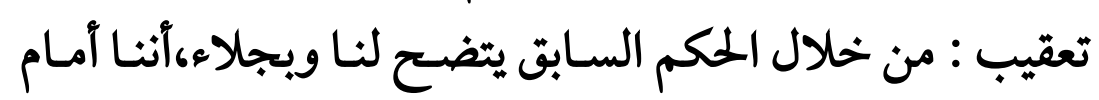
قياس إجرائي قضائي عملي،اتضحت فيه جميع معالم القياس وأركانه،من

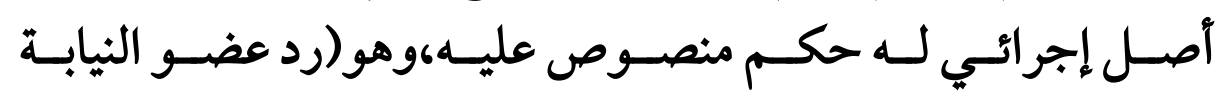

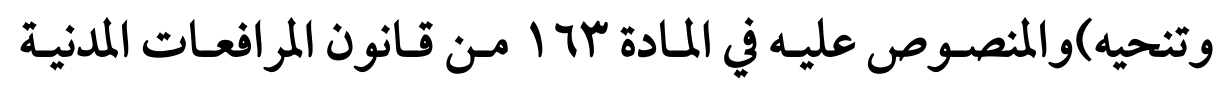

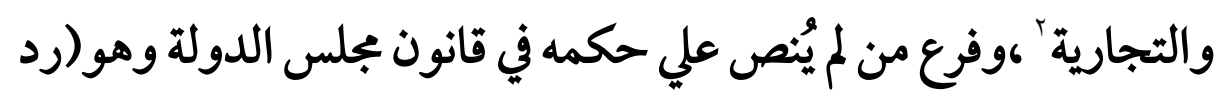

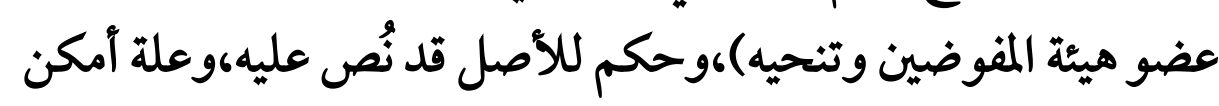

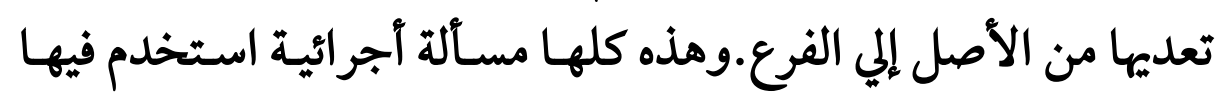
القياس الاجرائي بشكل واضح.وهنا قد يقول البعض أننا لسـنا آمامـا

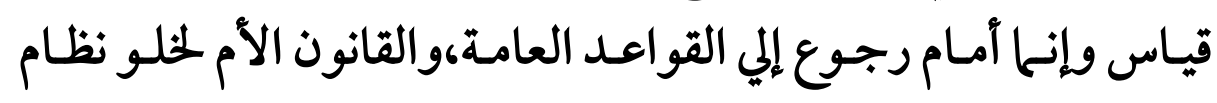
إجرائي معين من تنظيم بعض مسائله ! وهنا يمكن أن نرد ونقول: يمكن

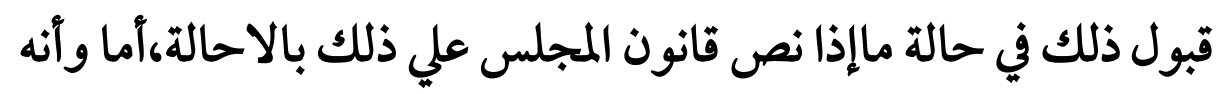

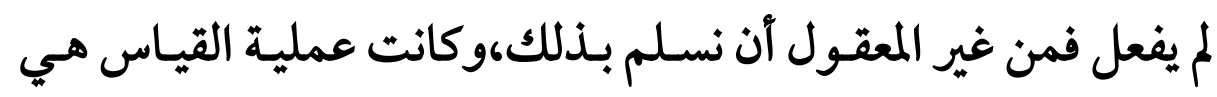

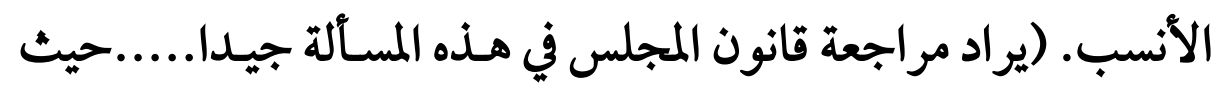

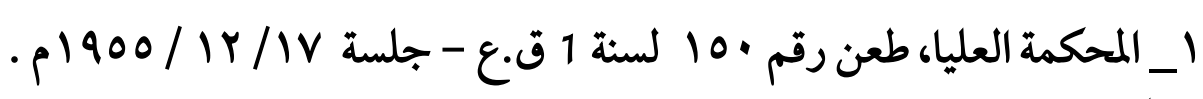

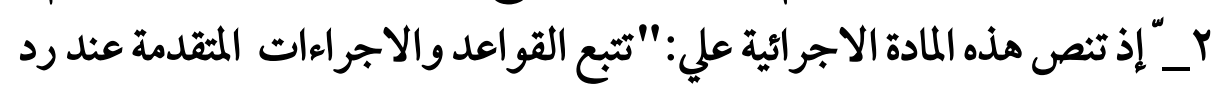

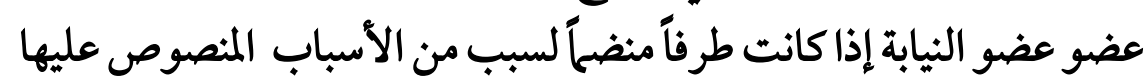

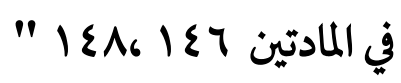


يوجد نص ينص علي: ومن حيث أن المادة به من القانون رقم Vع لسنة

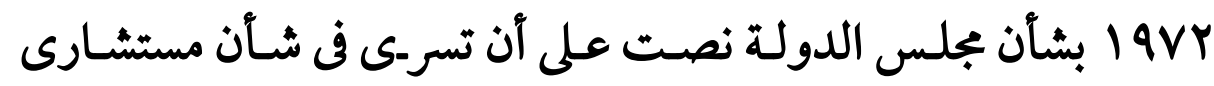

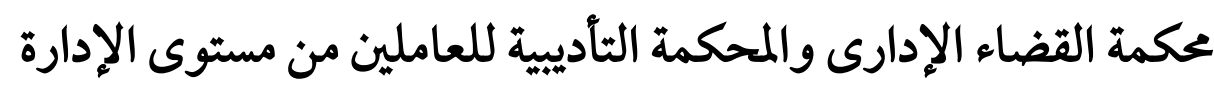

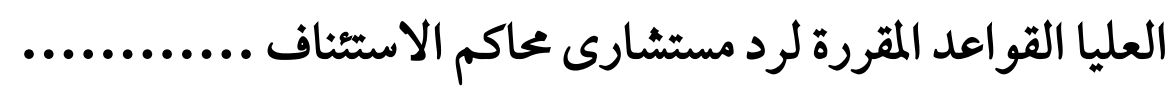
والنص المتقدم يقرر أصلا عامَ يتصل بأسس النظام القضائي

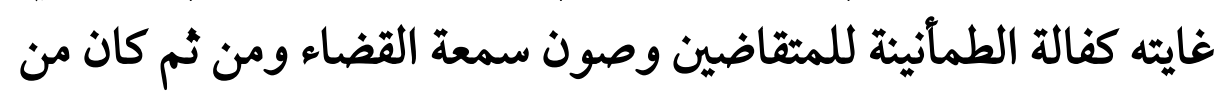

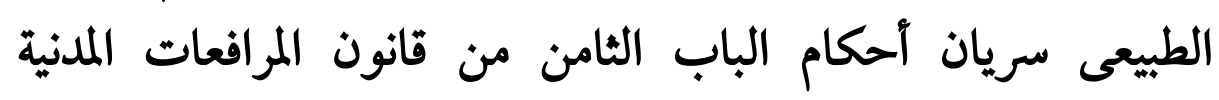

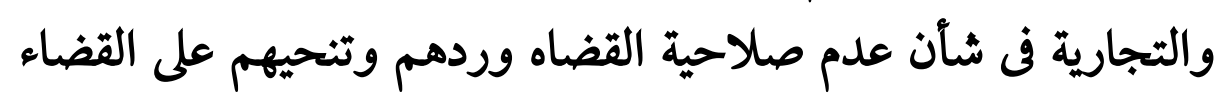

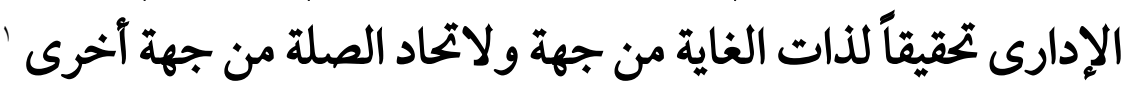
ج_قياس (الإقرار في غير بجلس القضاء) علي (الإقرار في بجلس القضاء ) في الحكم،وهو الصحة.

وفي ذلك تقول محكمة النقض:" المثفق عليه عند فقهاء الحنفية أن

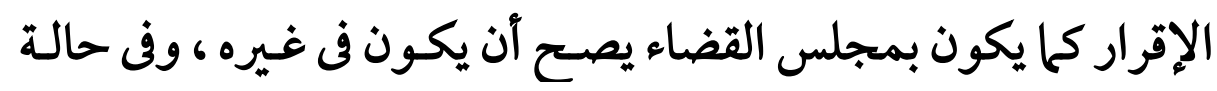

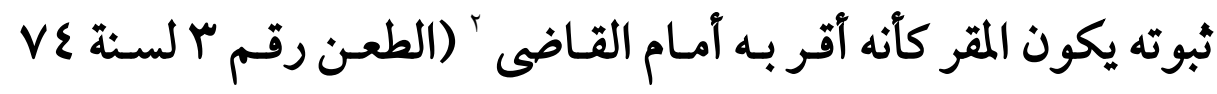

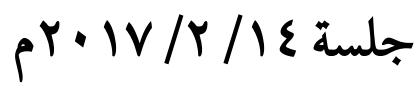

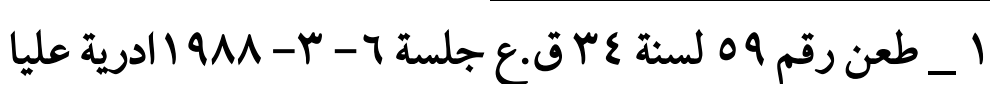

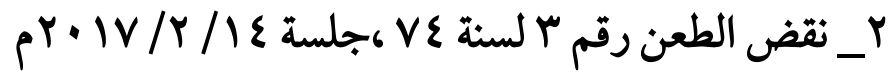




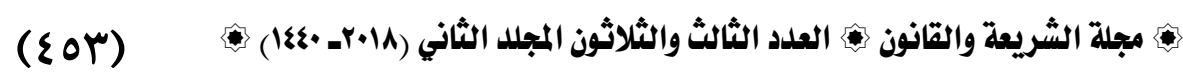

د_قياس حالة (عدم تقديم صسورة مـن مرسوم قـانوني ذا صـلة بالدعوي) علي حالة (عدم تقديم صورة مطابقة لأصل الحكم المطعون

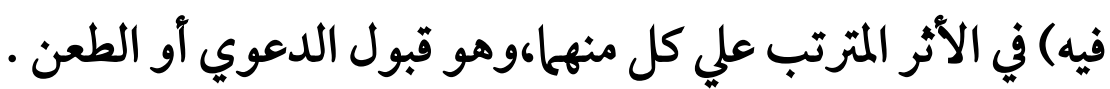
وفي ذلك تقول محكمة النقض:". ...متى كان المرسوم المطعون فيه فيه قد نشر بالوقائع المصرية و أصبح بمجرد نشره معلوما للكافة فإن عدم دمدي

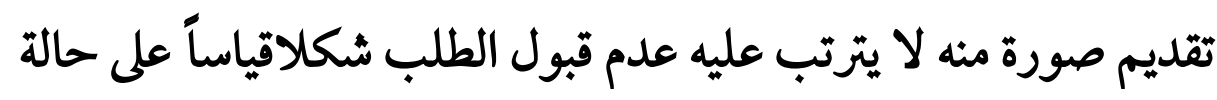

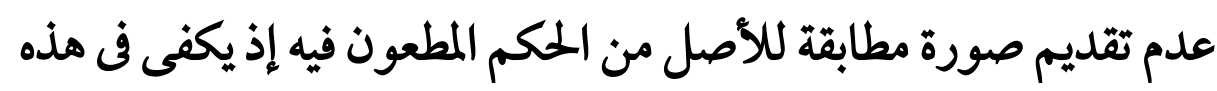

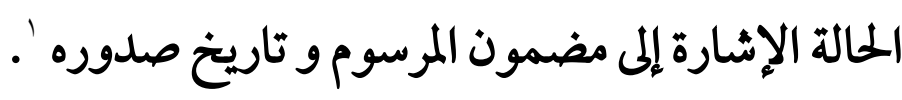
•_قياس حالة (انتهاء الدعوي دون فصل في موضوعها،تحيكا) علي حالة (انتهاء الدعوي دن فصل في في موضوعها،صلحاً)،في الحكم،وهو تثفيض الرسوم القضائية عليها إلي النص .

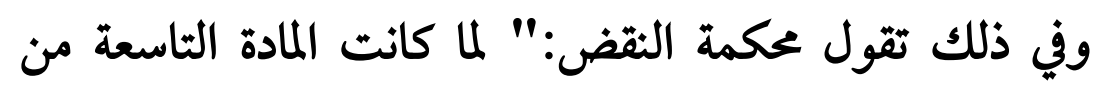
القانون رقم •ه لسنة ع ع 1 الخاص بالرسوم القضائية في المواد المدنية المعدل بالقانون رقم 77 لسنة 1978 تنص على انه " لا تحصل الرسوم النسبية على أكثر من ألف جنيه فإذا حكم فى الدعوى بأكثر من ذلك

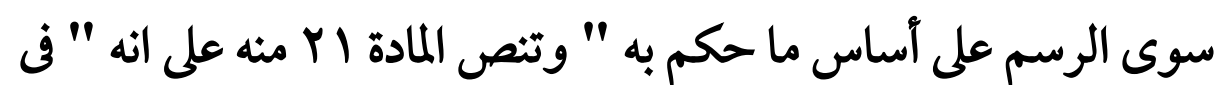

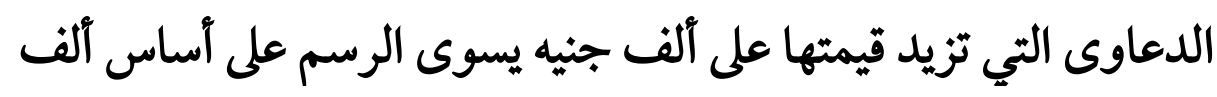

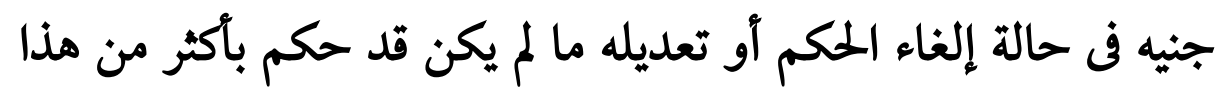

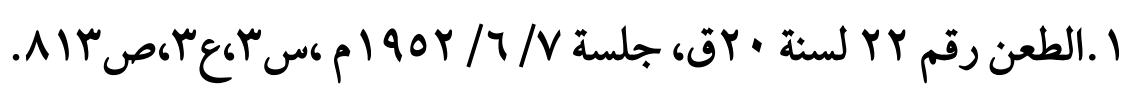


المبلغ فيسوى الرسم على أساس ما حكم به ........." والمستفاد من

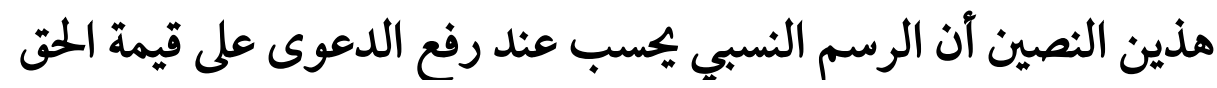

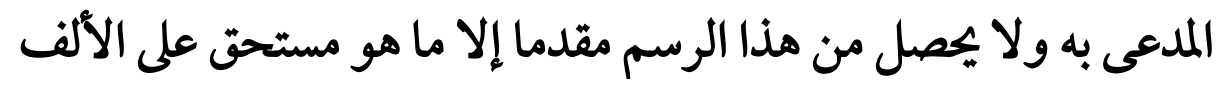

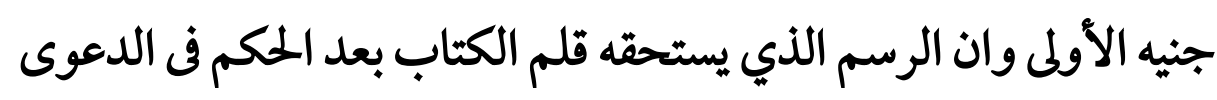

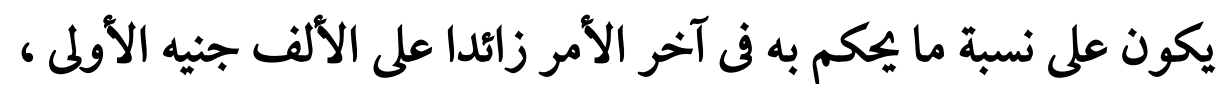

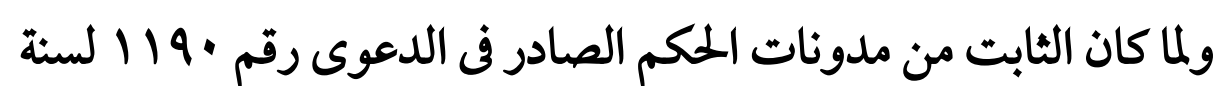

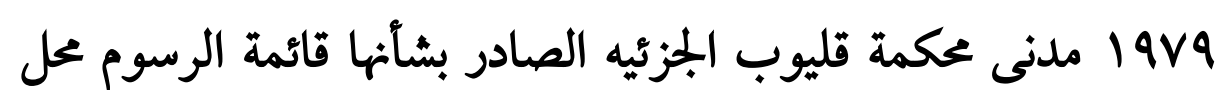

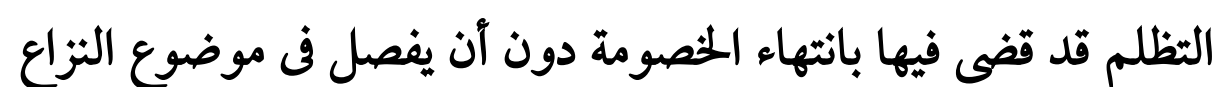

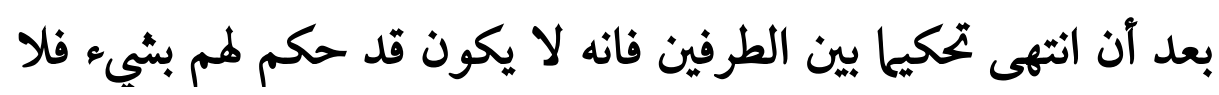

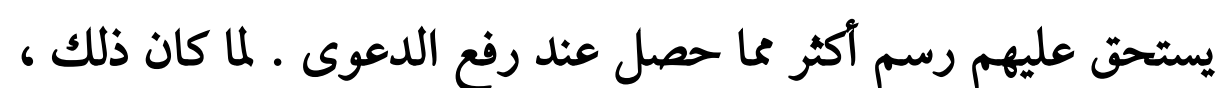

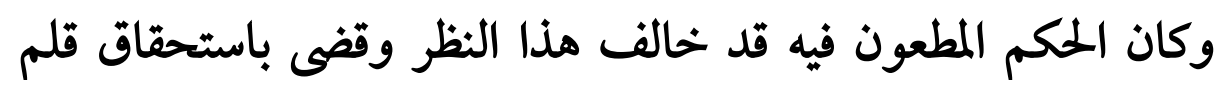

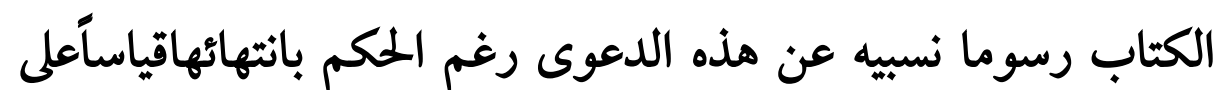
الصلح فانه يكون قد خالف القانون واخطأف تطبيقه' .

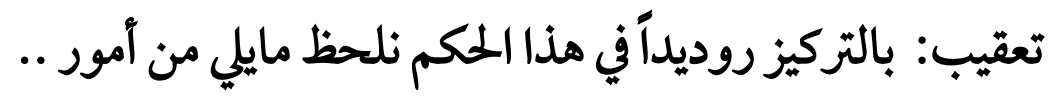

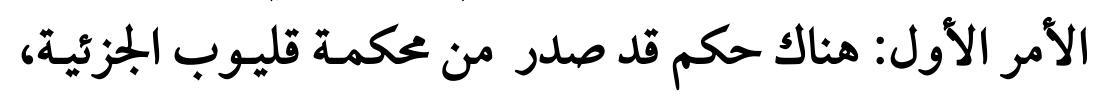

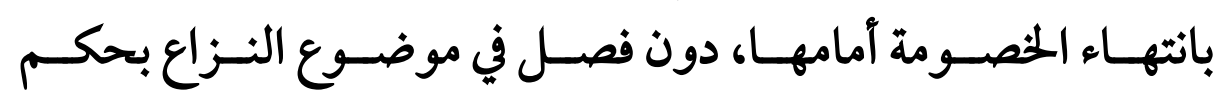

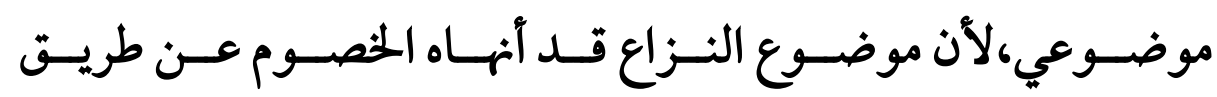
التحكيم،والمفترض أن المحكمة قد اطلعت عليه.

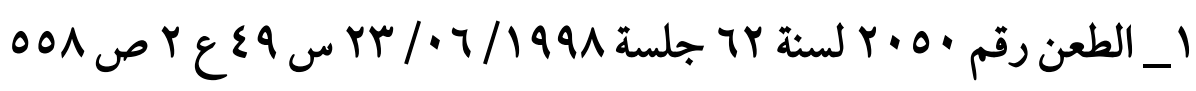




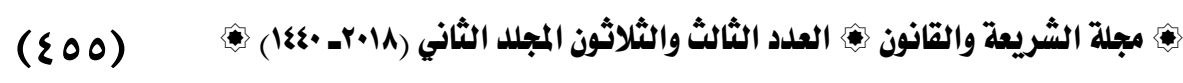
الأمر الثاني: أنه رغم انتهاء النزاع تحكيلاًبعيداً عن ساحة

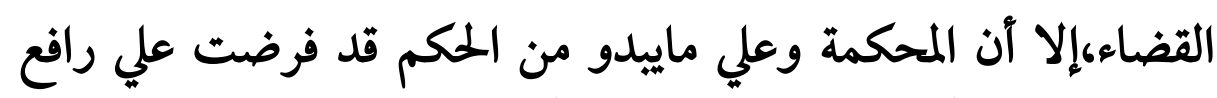

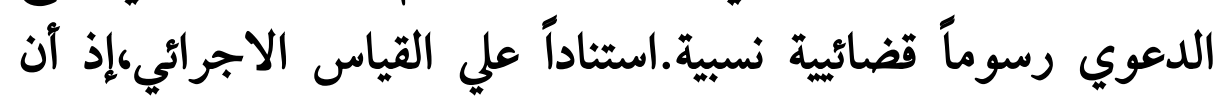
النزاعات المنصوص علي اسحقاق قلم الكتاب نصف الرسوم النسبية

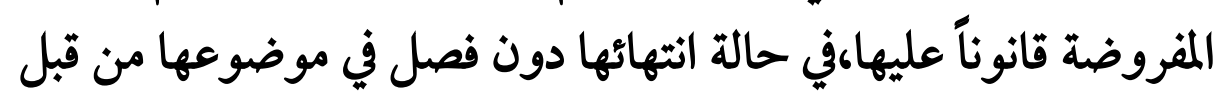

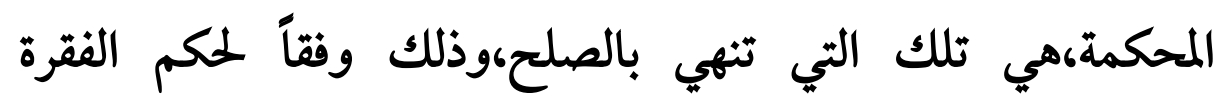
الخامسة،من المادة السادسة،من قانون الرسوم القضائية رقم ، 9 لسنة ع \1 ام،والتي تقول: " تخفض الرسوم إلي النصف في الأحوال الآتية

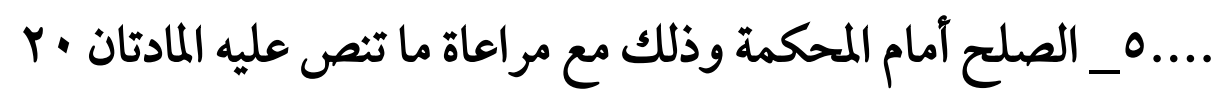

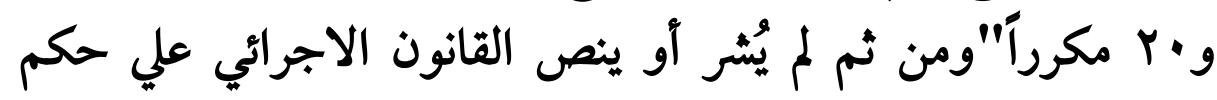
النزاعات التي تنتهي دون حكم في موضوعها من قبل القضاءووإنها انتهت بالتحيكم،فقامت المحكمة بقياس انتهاء الدعوي بالتحكيم علي انتهائها بالصلح - التحكي الأمر الثالث:قام المحكوم عليه بالرسم،بالطعن علي هذا الحكم

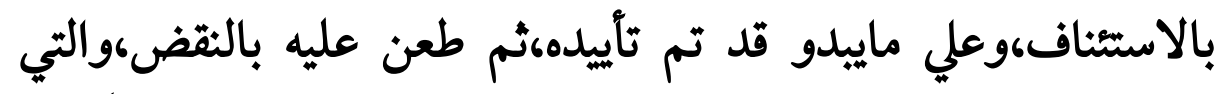

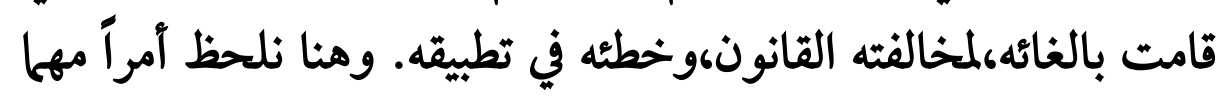
للغاية،وهو آن محكمة النقض وإن كانت قد آلغت حكم الاستئناف فهي لم تلغه استناداً علي ماقامت به المحكمة الجزئية من قياس، أيدته فيها

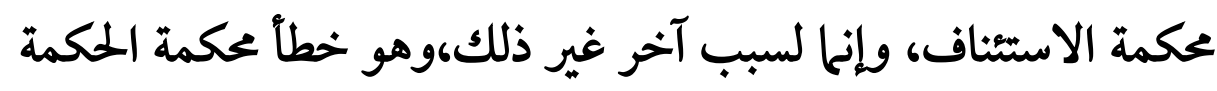


في تطبيق القانون،والذي يقضي بأنه طالما لم تحكم المحكمة في الدعوي،فلا

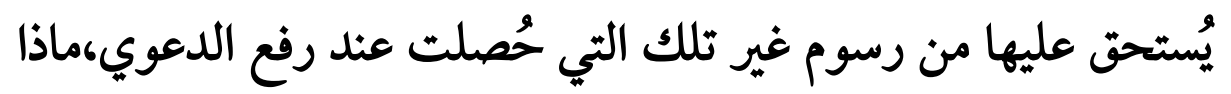

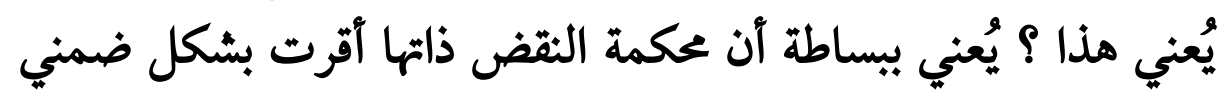

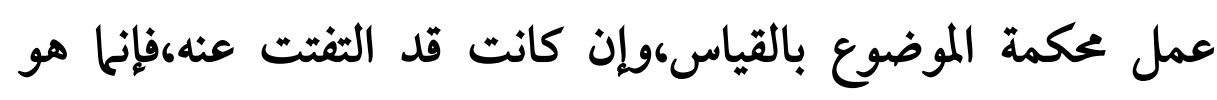
لاستخدامه في غير محله.

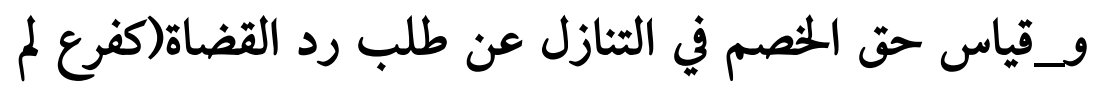
ينص القانون الاجرائي علي حكمه) علي حقه في ترك الدئ الدوي (كأصل نص القانون الاجرائي عل حكمه). وفي ذلك تقول محكمة النقض:"..إن المواد ومابعدها من قانون المرافعات في شأن عدم صلاحية القضاة وردمهم

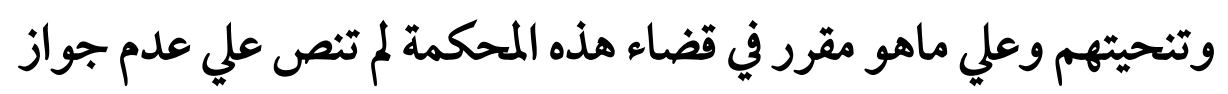

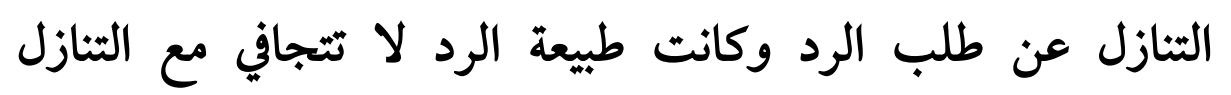

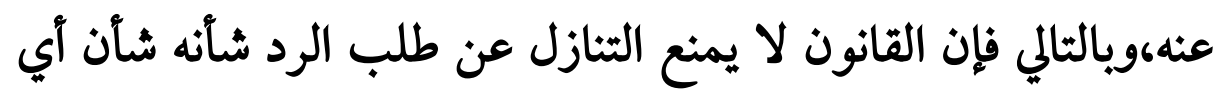

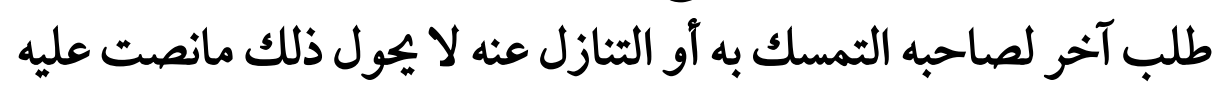

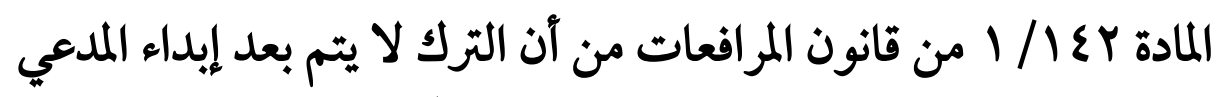

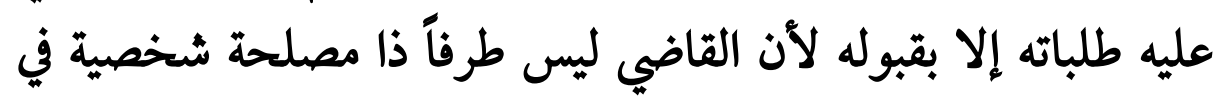




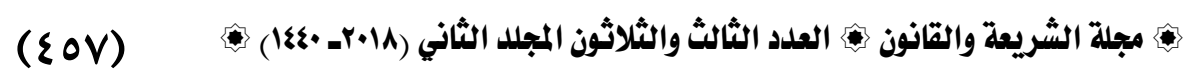
الخصومة ،وترتيباً علي ذلك أنه في حالة قيام طالب الرد بالتنازل عن طلبه

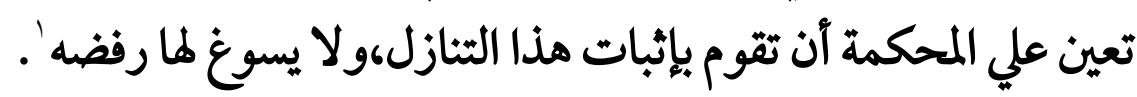

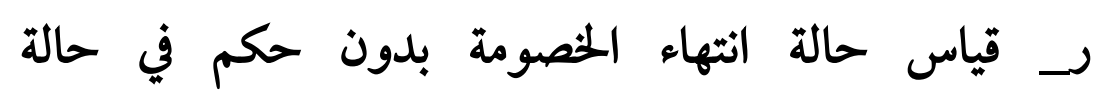
الاستئناف،بسبب تنازل المدعي = المحكوم له =(كفرع لم ينص القانون علي حكمه) علي حالة ترك الخصومة (كأصل نص القانون علي حكمه) من ناحية تحديد الخصم الذي يتحمل الرسوم القضائية .

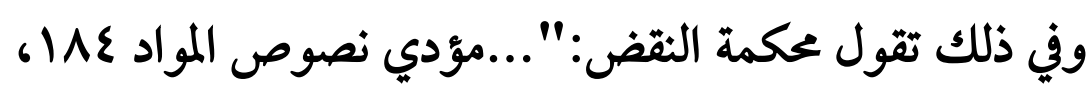

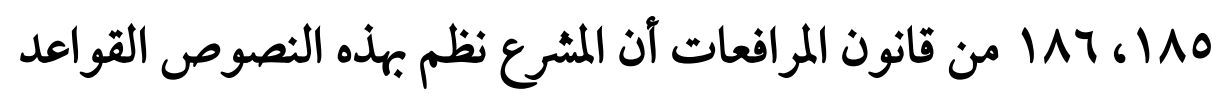
التي تحكم تحديد الخصم الذي يتحمل الرسوم القضائية والمصاريف

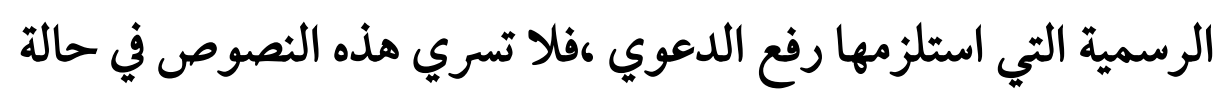
انهاء الخصومة بغير حكم في الدعوي،وكان هذا الانتهاء يرجع الي الي أسباب مختلفة،نظم قانون المرافعات في بعضها الخهم الخصم الذي الذي يتحمل

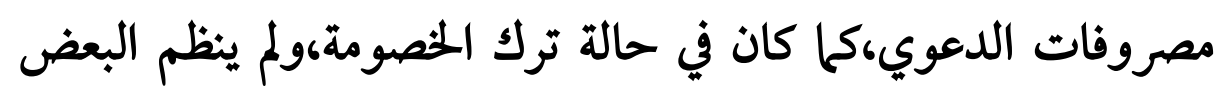
الآخر،كحا في حالة انتهاء الخصومة في الاستئناف بغير حكم بسبب تنازل

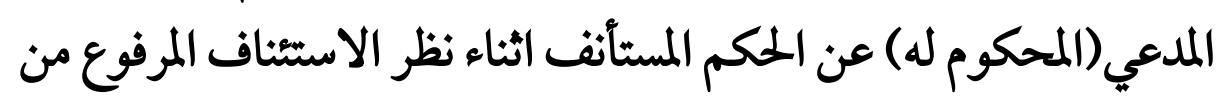

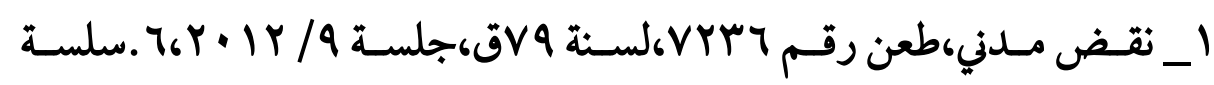

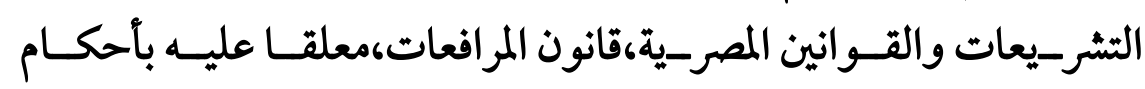

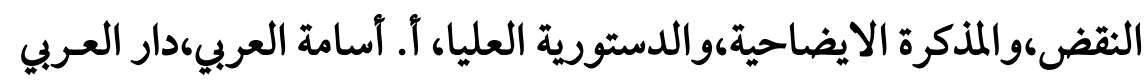

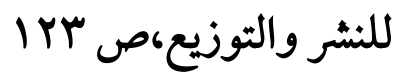


المحكوم ضده، إذ يترتب علي هذا الثنازل أن يصبح الحكم المطعون فيه

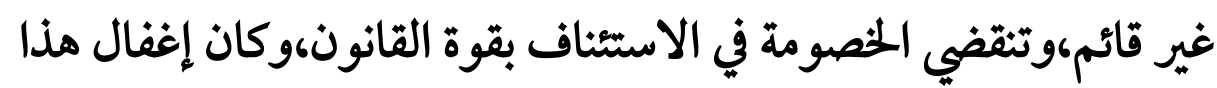

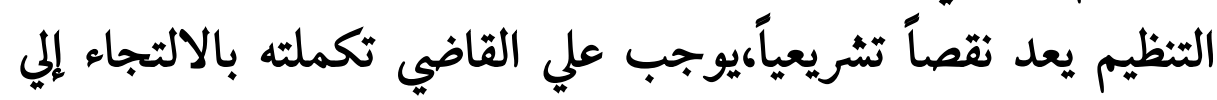

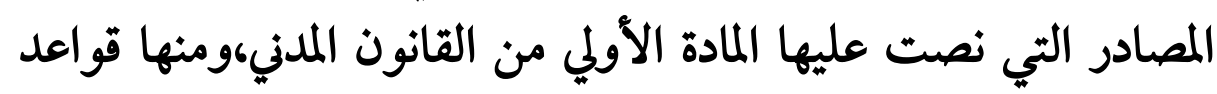

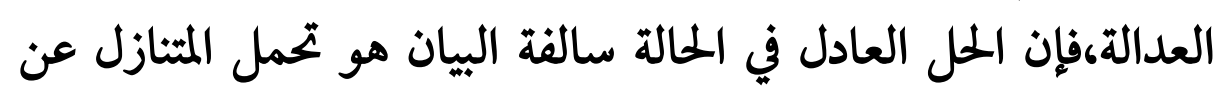

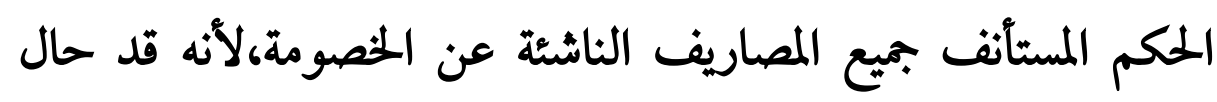

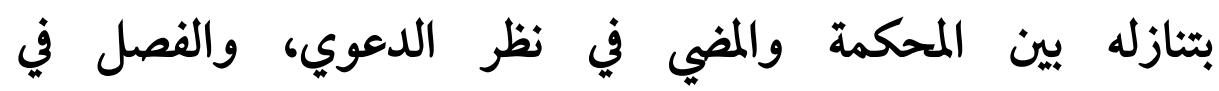

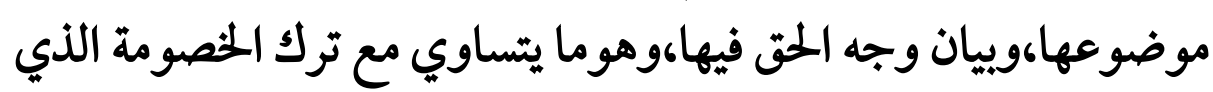

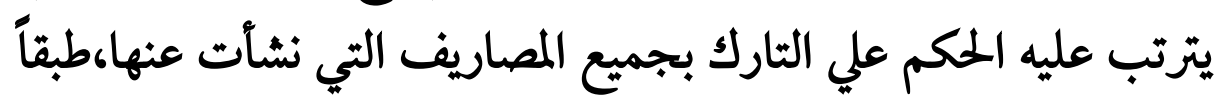

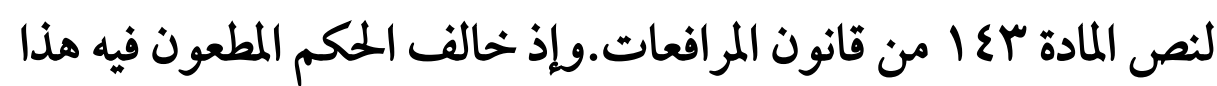

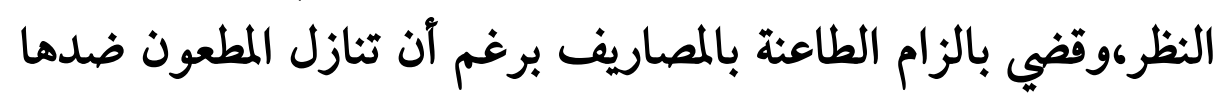

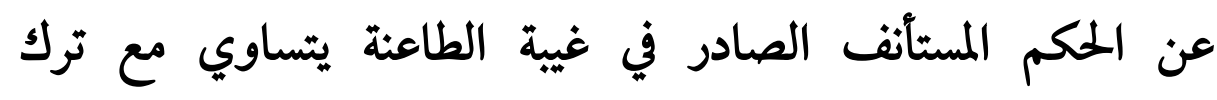

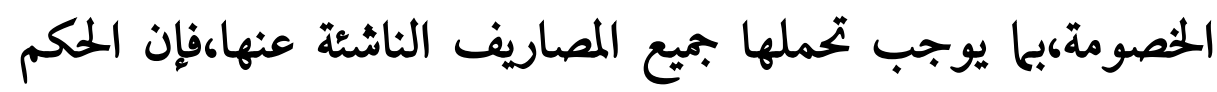

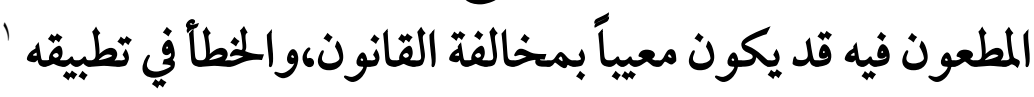

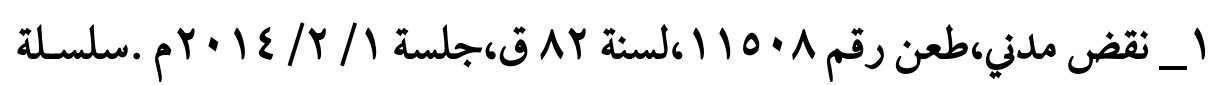

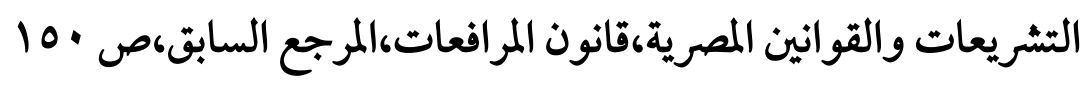




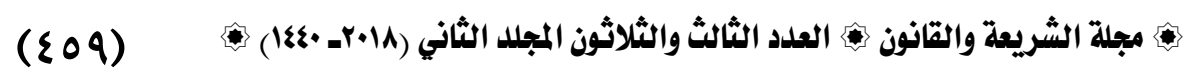
رـ قياس الإقرار المكتوب الموثت بمكاتب التوثيق بترك الدعوي

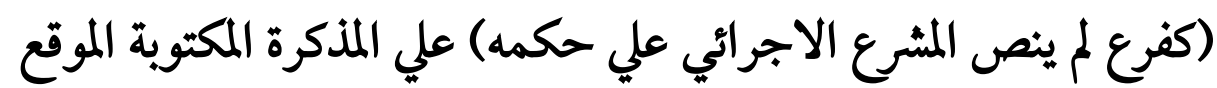

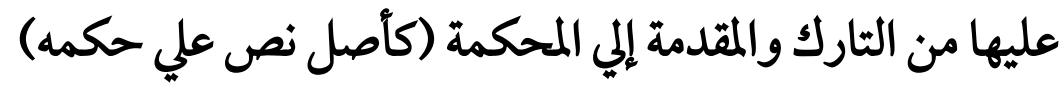

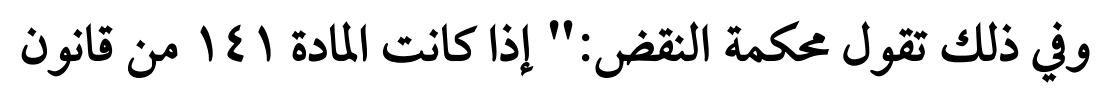

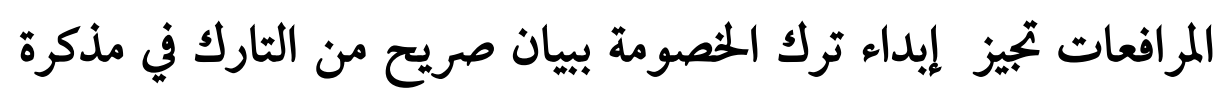

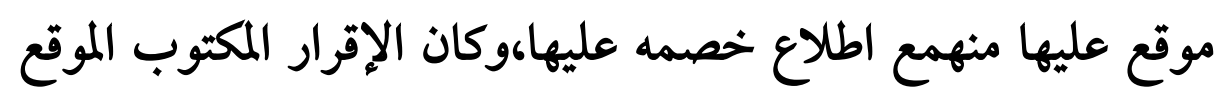

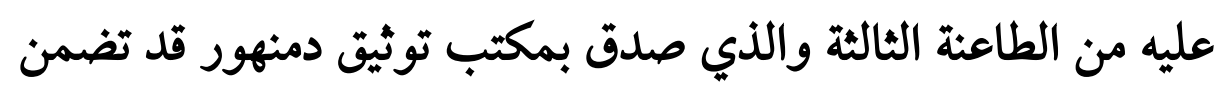

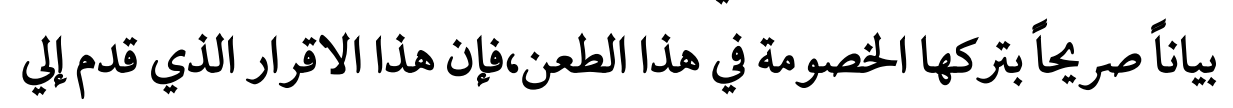

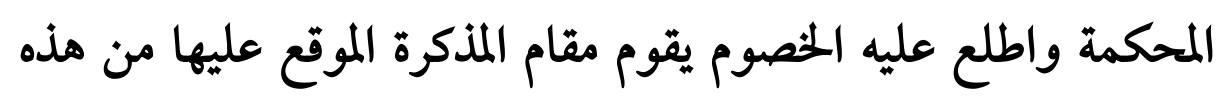

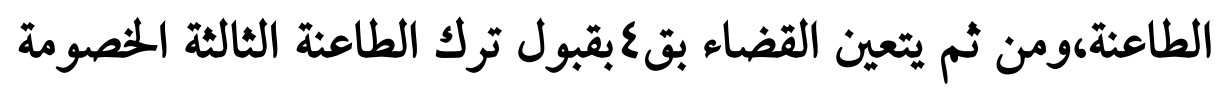
في الطعن. ز_ قياس الدور الذي تؤديه المحاكم الوطنية في تعيين المحكمين في حالة التحكيم المؤسسي(كفرع لم ينص علي حكمه) علي الدور الذي تقوم به ذات المحاكم في تعيين المحكمين في حالة التحكيم الحر.

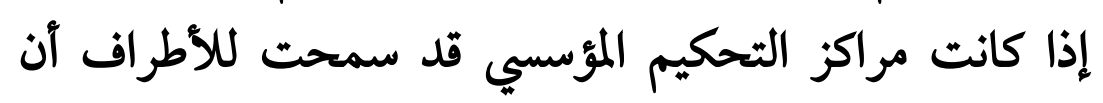

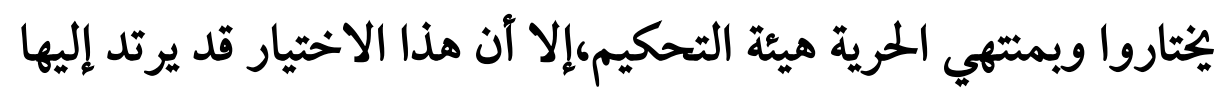

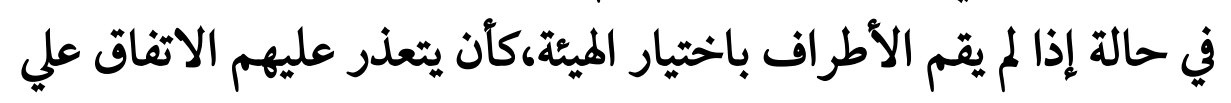
تعيين المحكم الواحد،أو آو أهمل آحدهم آو قصر في تعيين محكمه إذار الميثة

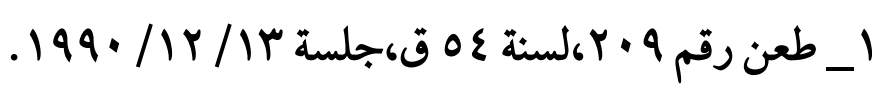


كانت هيئة التحكيم مشكلة من ثلاثة أو أكثر،وهنا يقوم المركز بدور

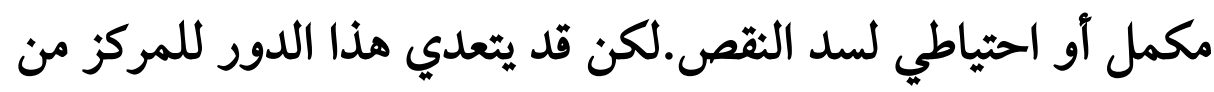
بجرد سد النقص إلي كون تعيين المحكم حق أصيل له ابتداءا،لذا فالدور الذي تقوم به مراكز التحكيم المؤسسي في تعيين المحكمين يتدرج في قوته

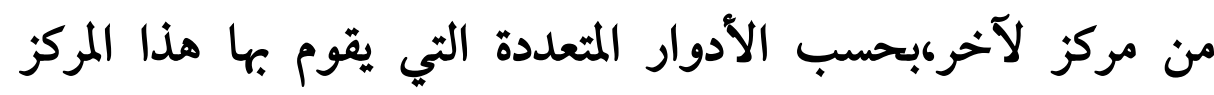
التحكيمي المؤسسي أو ذاك بصدد تنظيم وإدارة العملية التحيكيمة. ولما كان الدور الذي تؤديه المحاكم القضائية في هذا الشأن ماثلّ

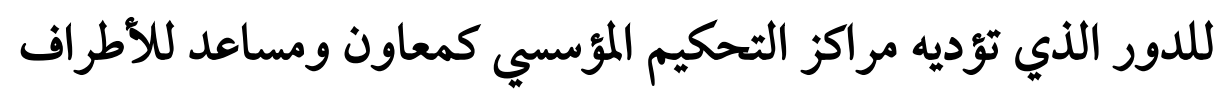
في تشكيل هيئة التحكيم،فإن لوائح التحكيم المؤسسي لم تنص المرئ علي

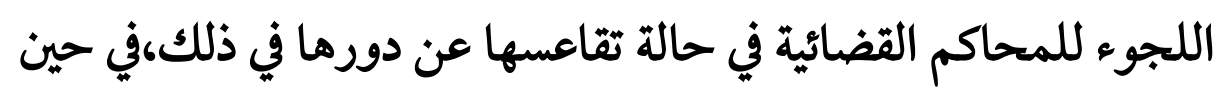
نصت عليه لوائح التحكيم الحر.ومع ذلك فإن عدم نص لوائح التحكيم المؤسسي علي ذلك لا يمنع من إمكانية اللجوء إلي المحاكم الوطنية للمساعدة قياساً علي تدخلها في التحكيم الحر. نخلص مما سبق إلي ان فكرة العمل بالقياس،كأحد وسائل الاجتهاد القانوني،علي الساحتين الفقهية والقضائية،فكرة ليست ببعيدة عن الجمواز العقلي،ولا التطبيق العملي،إذ الفقه

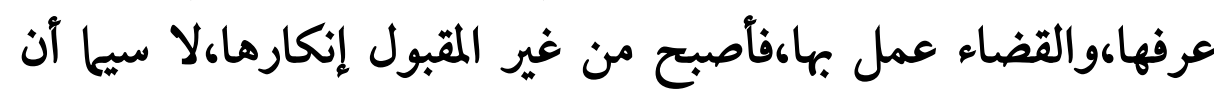

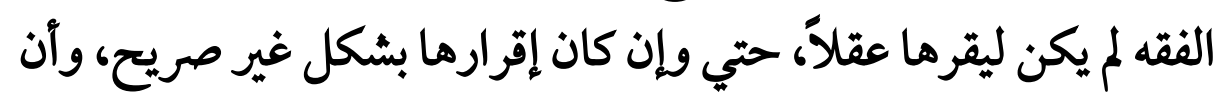
القضاء لم يكن ليعمل بها فيا ينظره من نزاعات، إلا لداعي الحاجة التي 


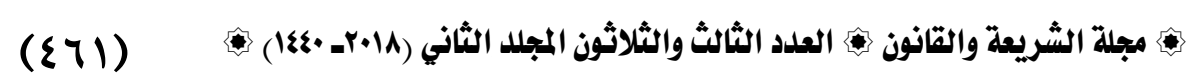

تخدم مصالح الخصوم،ووقت القضاءهومرفق العدالة ،حتي وإن كانت

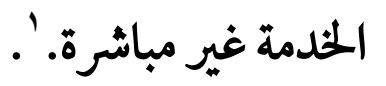

ا _ لم يكن الفقه الإسلامي،في بجال علم القضاء، ببعيد عن معرفة فكرة القياس

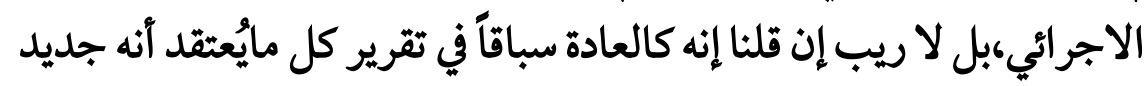

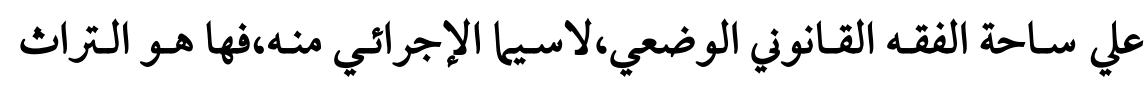

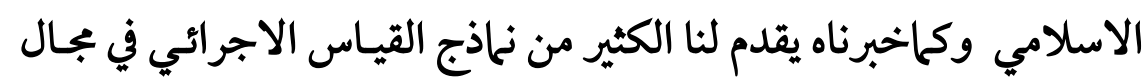
الدعاوي والبينات،ومن ذلك علي سبيل المثال مايلي :

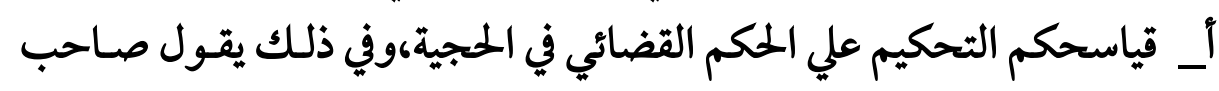

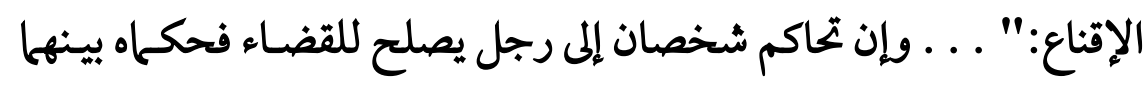

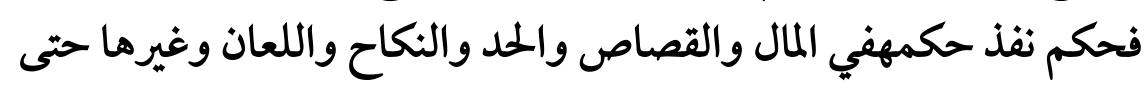

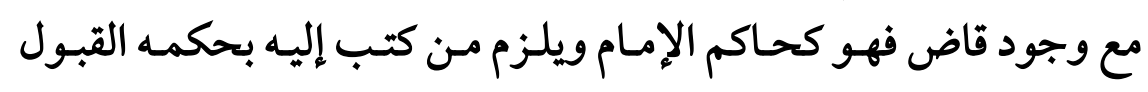

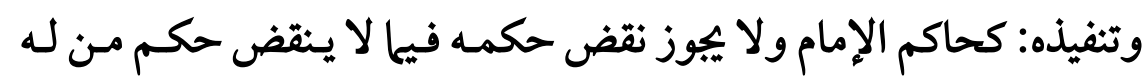

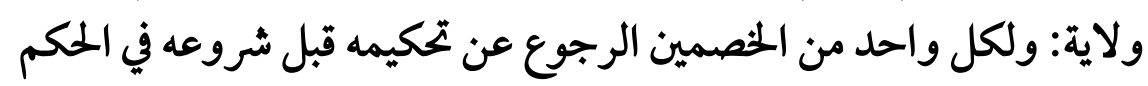

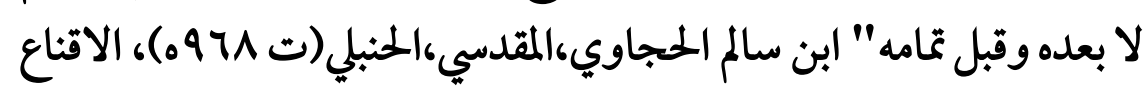

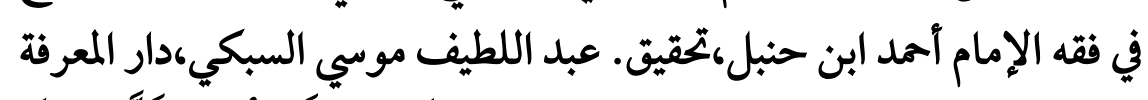

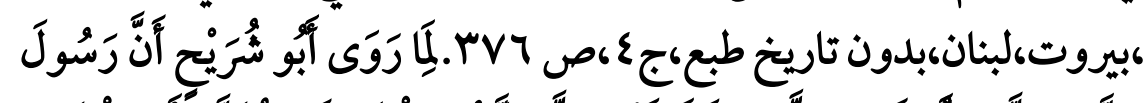

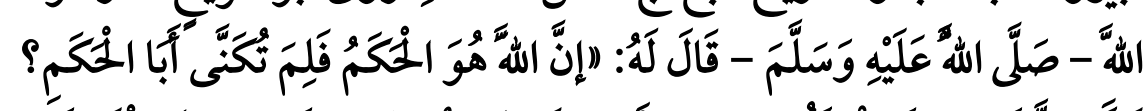

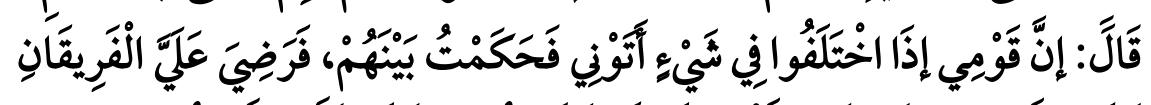

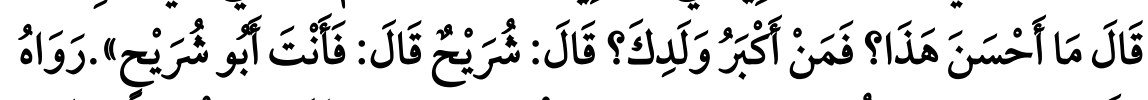

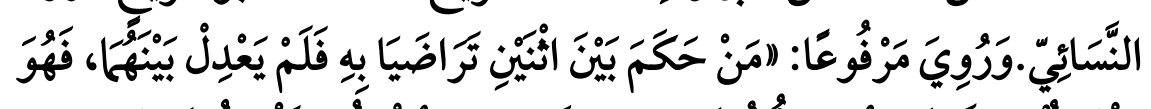

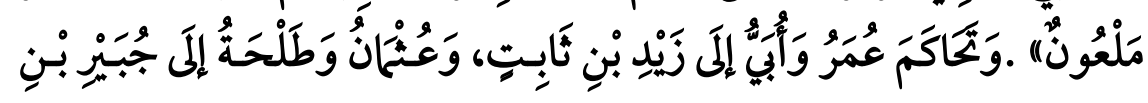




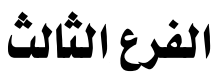

تعريف القياس الاجرائي في ضوء موقف الفقه والقضاء الاجرائيين،

$$
\text { وبيان أركانه }
$$

أولاً _تعريف القياس الاجرائي في ضوء موقف الفقه والفياء

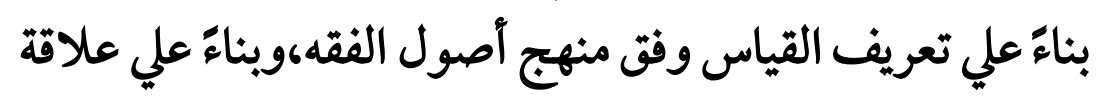

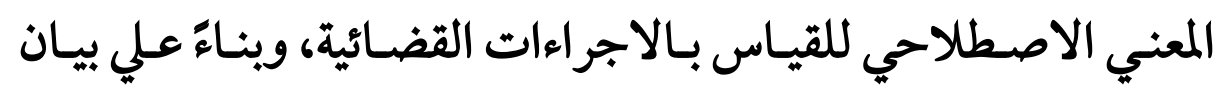

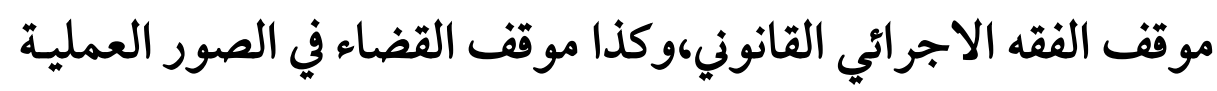

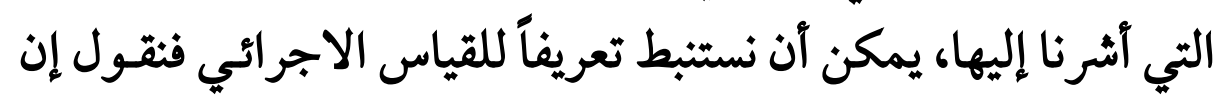

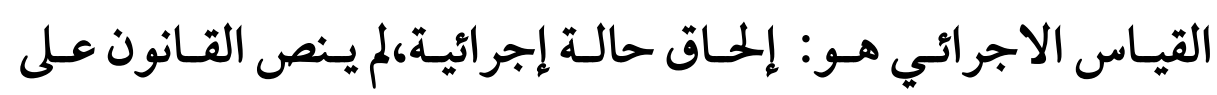

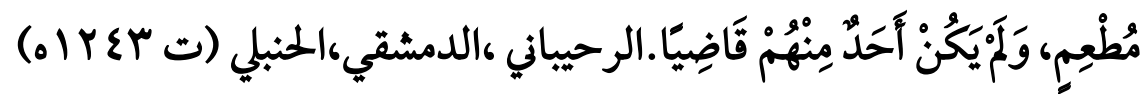

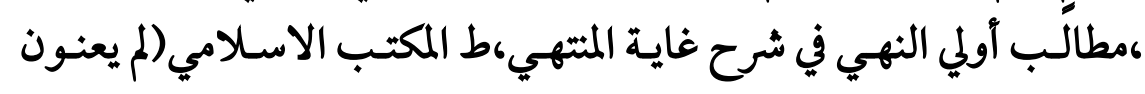

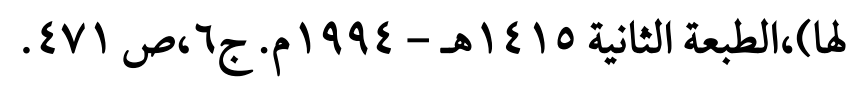

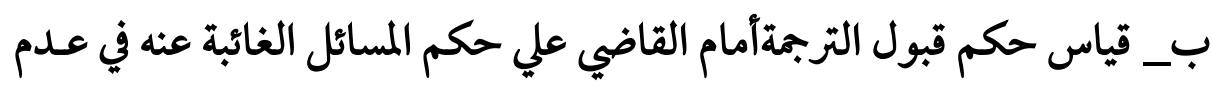

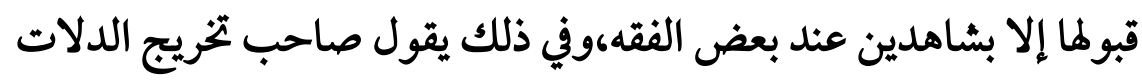

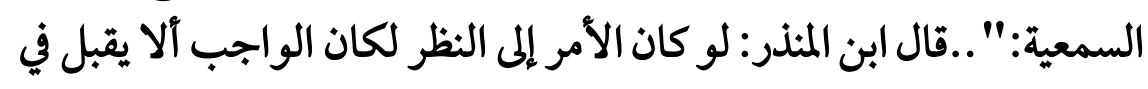

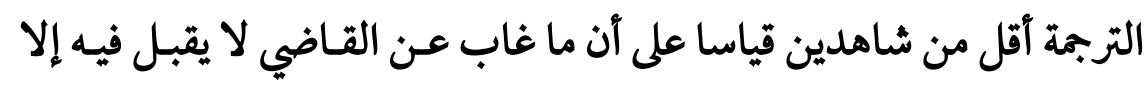

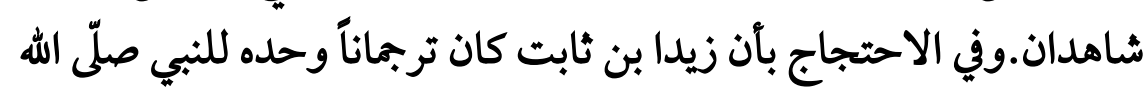

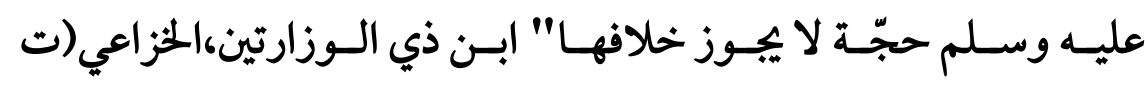

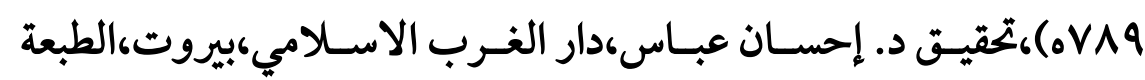

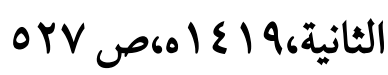




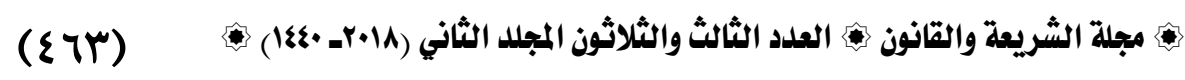
حكمها،بحالة أخري ورد نص بحكمها، في الحكم الذي ورد به النص، لتساوي الحالتين في علة هذا الحكمب. ويشد من عضد ماذهبنا إليه،حكم المحكمة الإدارية العليا،التي

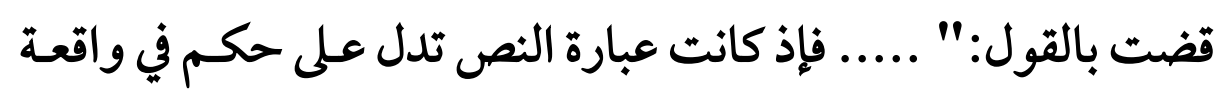

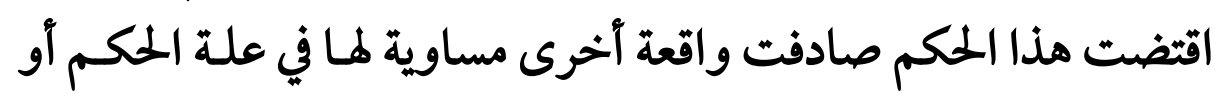

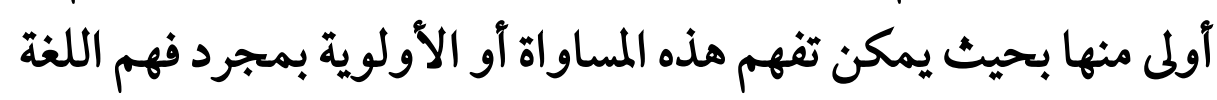

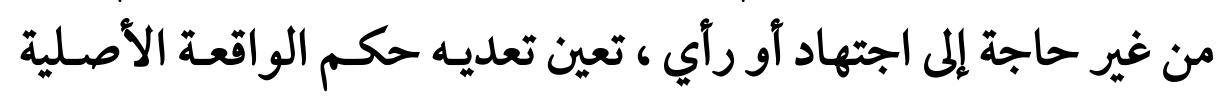

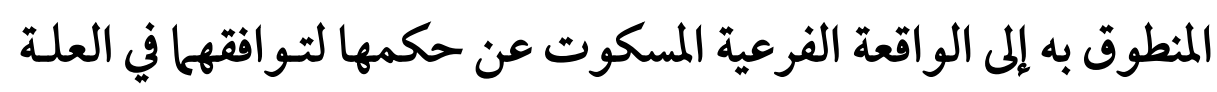

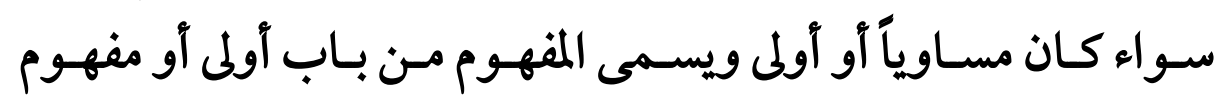

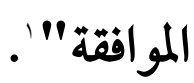

$$
\text { ثانياً__أركان القياس الاجرائي }
$$

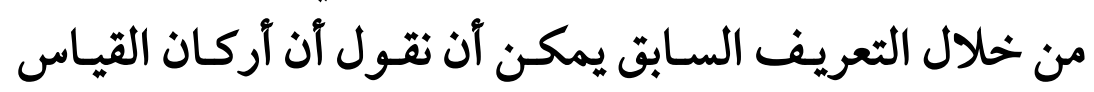

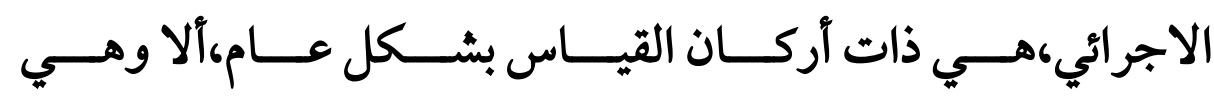
الأصل،والفرع،وحكم الأصل،والعلة،وذلك علي الثفصيل الآتي:

$$
\text { الركن الأول_الأصل }
$$

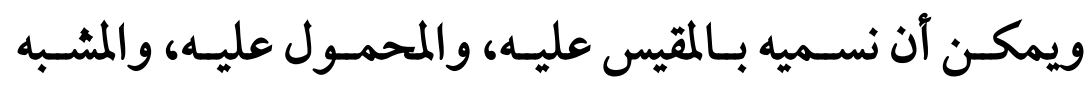

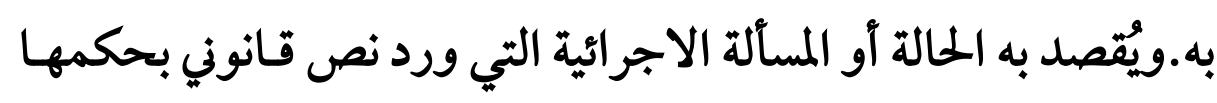

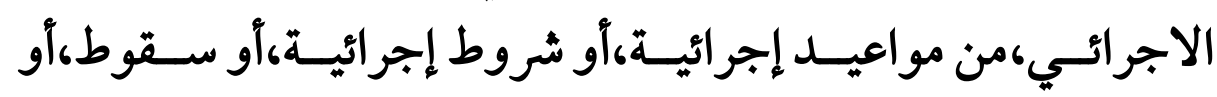

| _طعن رقم Y+ ابr لسنة Yo ق.ع - جلسة 11 - 2-2007،إدارية عليا 
انقطاع،....إلخ.ويمكن أن نطلق علي هذا الأصل أكثر من مصطلح،كأن نسميه بالمقيس عليه،أو المحمول عليه،أو المشبه به.

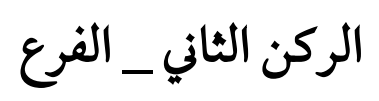

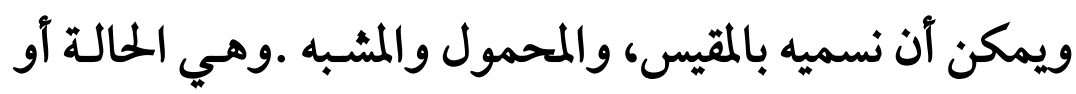

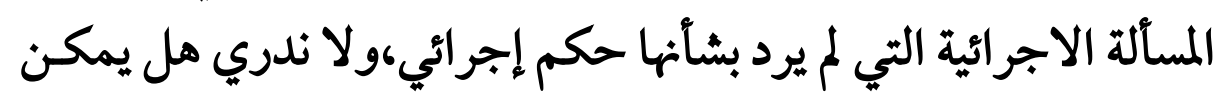

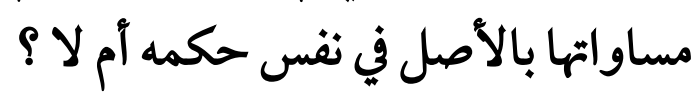

$$
\text { الركن الثالث_ حكم الأصل }
$$

وهو الحكم الاجرائي المنصوص عليه للأصل، ويراد آن يكون الأنمل

$$
\text { هو نفس الحكم للفرع. }
$$

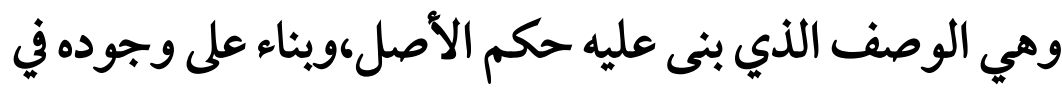

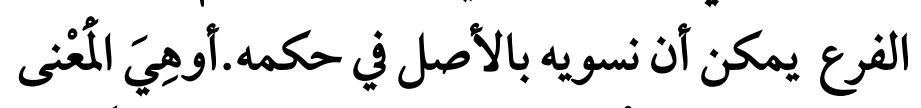

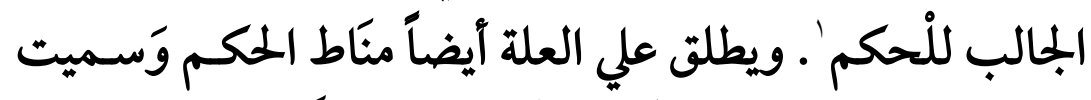

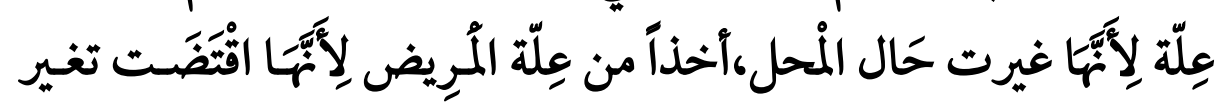
حاله '.كما يمكن أن نسميها بسبب الحمكم،وأمارته.

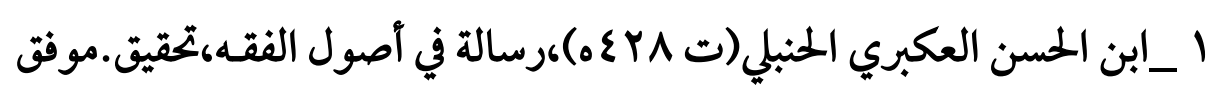

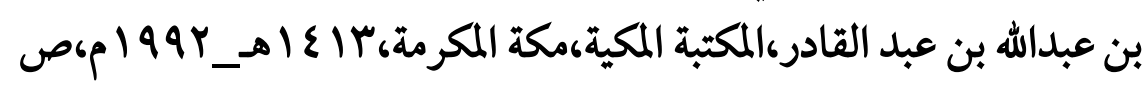

$$
\text { \1 }
$$

Y _ ابن الحسن العكبري،المرجع السابق، v9. 


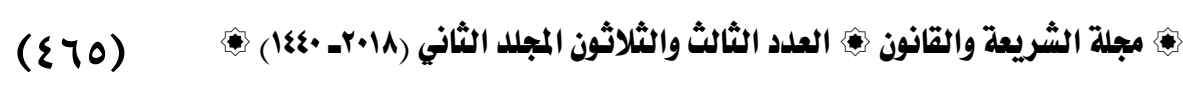

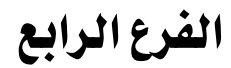 \\ أساس العمل بالقياس الاجرائي}

المراد بأساس القياس هو تحديـد القاعدة التي علي يُبني عليها الاعيا

القول بإمكانية القياس الاجرائي، ياتري هل أساس القياس هـو إدراسي

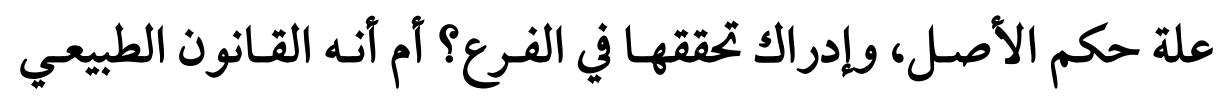

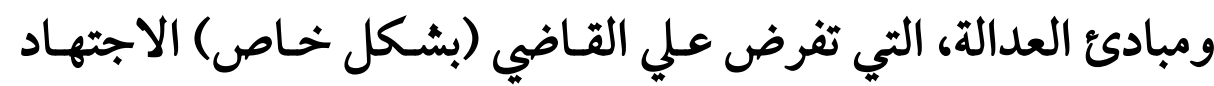
الاجرائي،حيث إذا ماوجد نفسه أمام فراغ إجرائي، فعليه أن يفتش عن إني

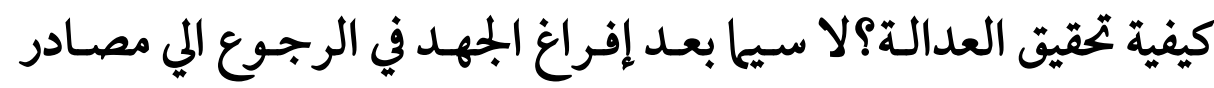

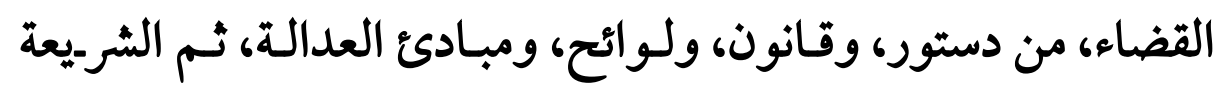

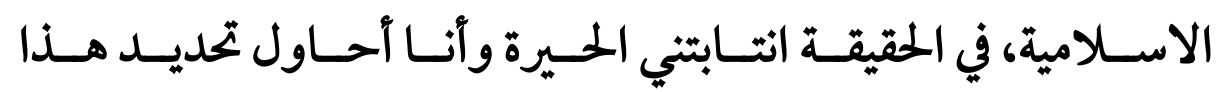

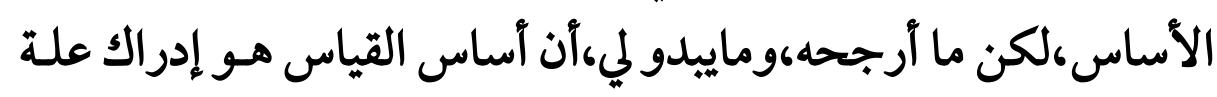

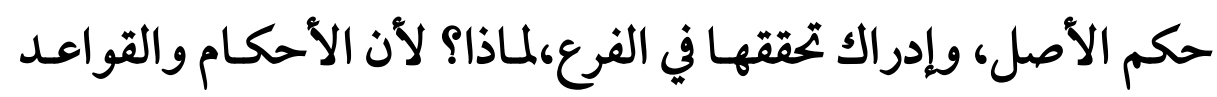

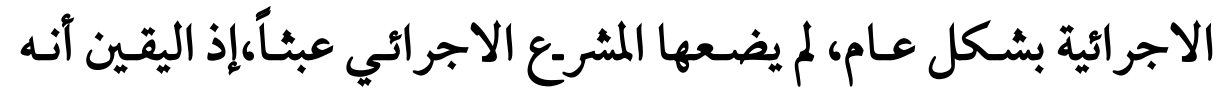
ماوضعها إلا لعلة،وهي تحقيق الصالح العام،من محاولة تحقيق العدالة في

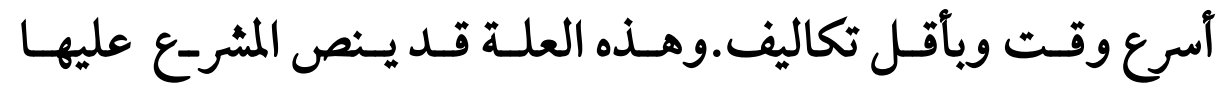

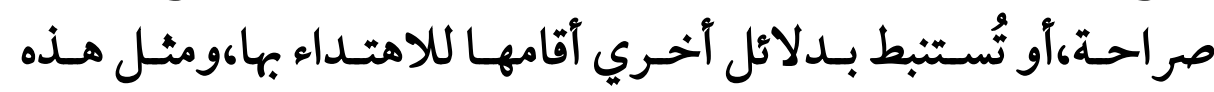

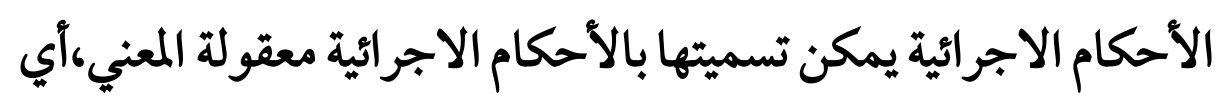
التي يمكن تعدية حكمها من الأصل إلي الفرع عن طريق القياس،سواء آلاء

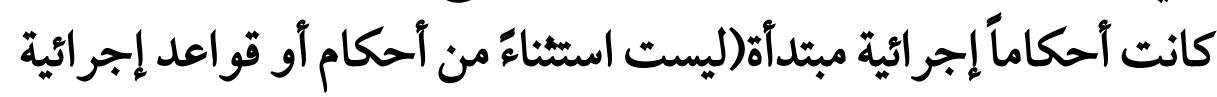

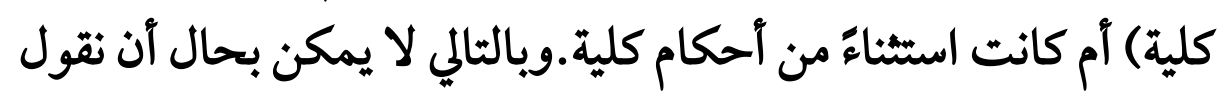


أن هناك قواعد وتشريعات إجرائية قد استأثر المشرع الاجرائي بعلم عللهاءأو لم يمهد السبيل إلي إدراكها' .

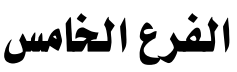

الفرق بين الثياس الاجرائي وبين الرجوع إلي

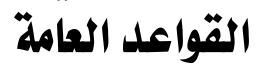

القياس الاجرائي كما قلنا آنفاً هو: إلحاق حالة إجرائية، لم ينص

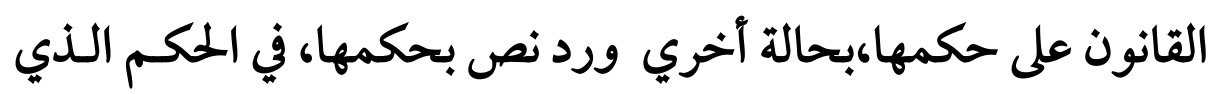

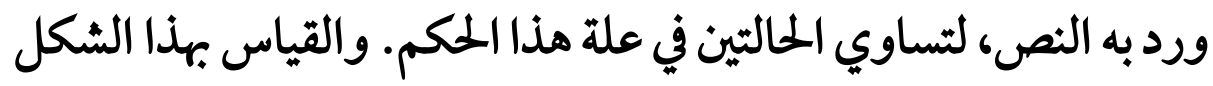

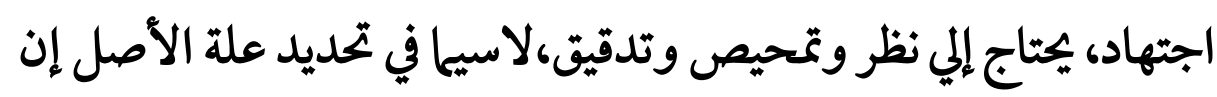

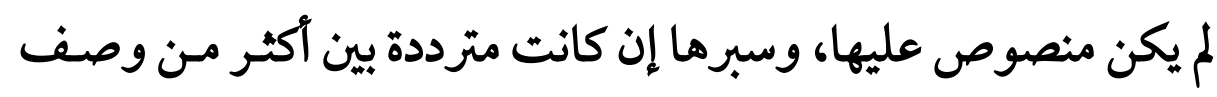

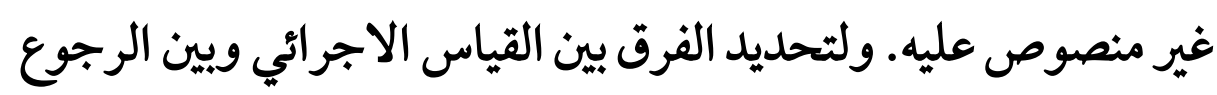

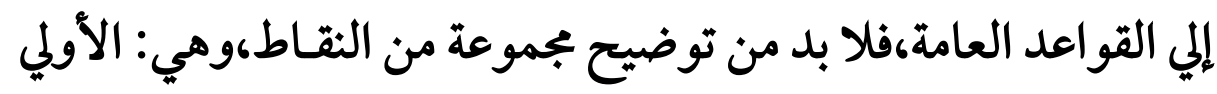

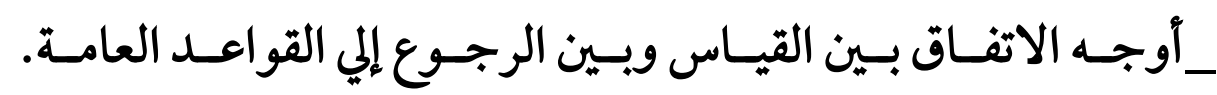

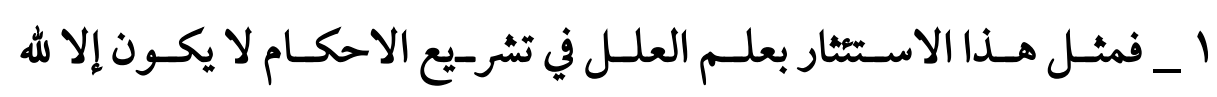

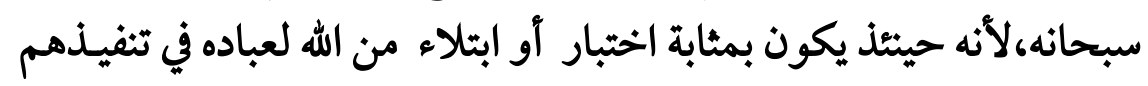

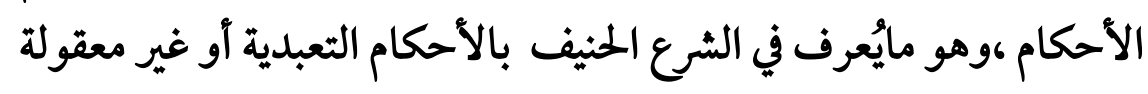

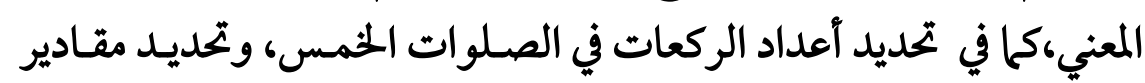

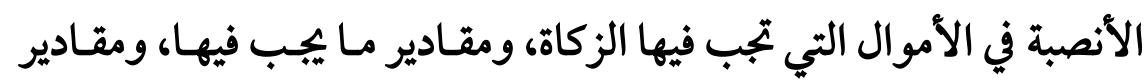

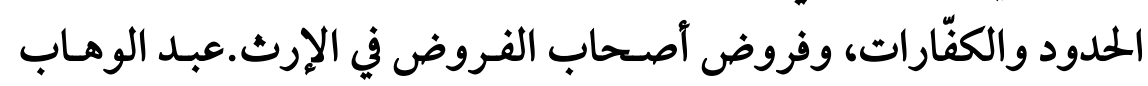

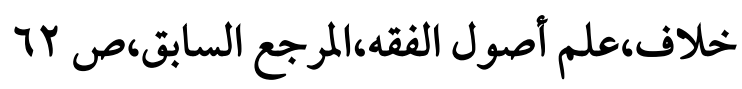




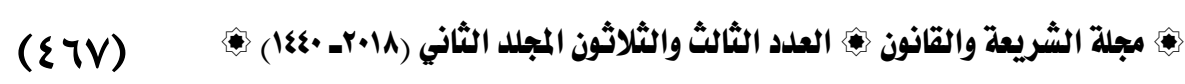

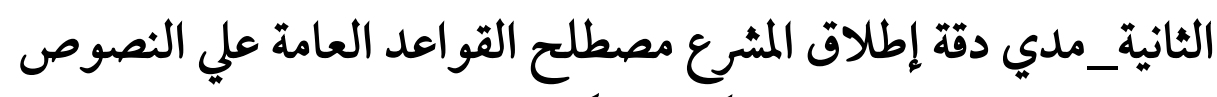

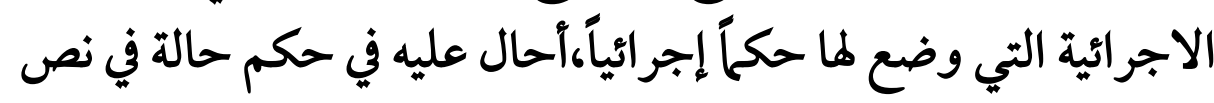
إجرائي آخر،أو ساوي بينه وبين حكـم حالة أخري في ذائ ذات النص ؟

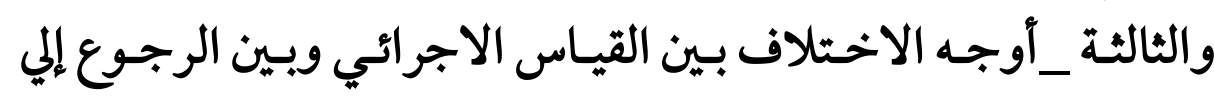
القواعد العامة،وذلك علي التفصيل الآتي :

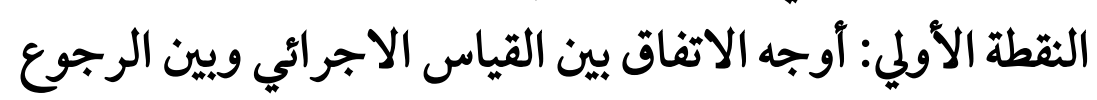

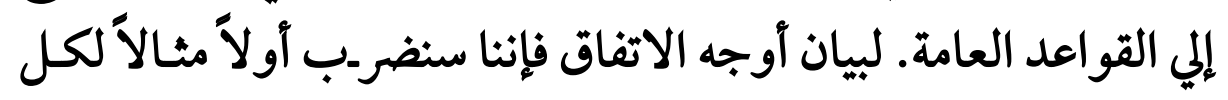
منه| كالتالي التي

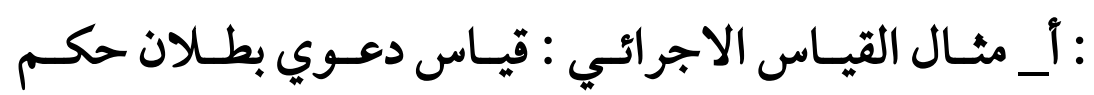

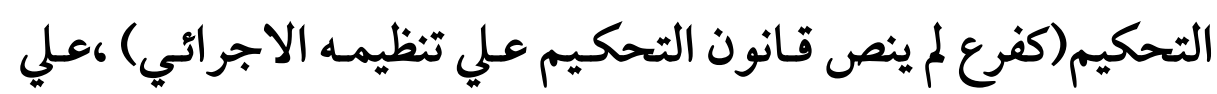
الدعوي بشكل عام(كأصل نص قانون المرافعات علي تنظيم الاجرائي

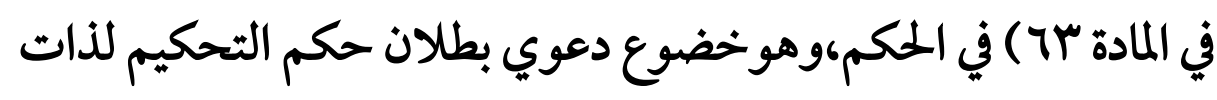
القواعد الاجرائية التي تحكم رفع الدعوي.

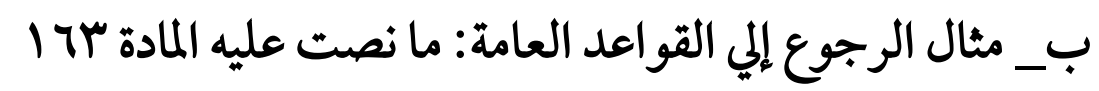

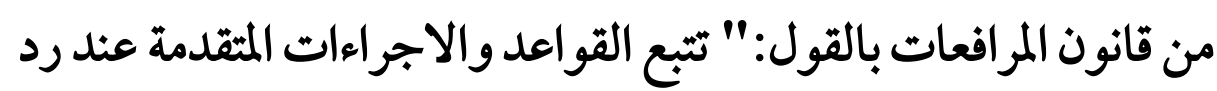

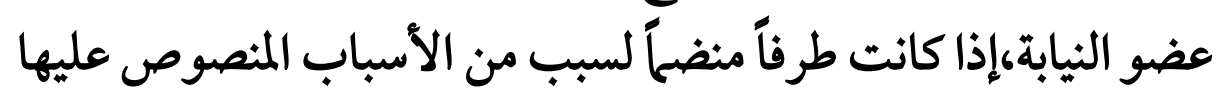

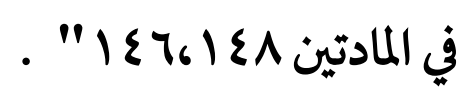

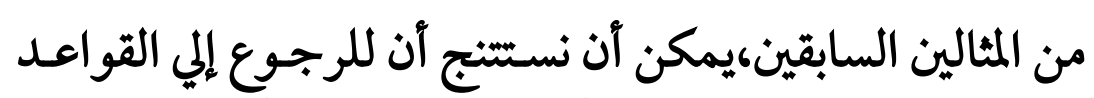

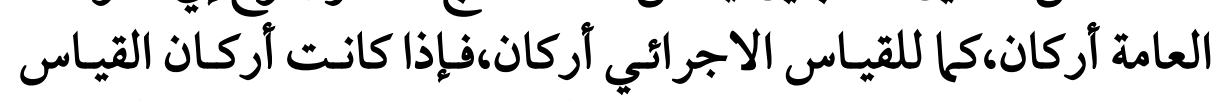

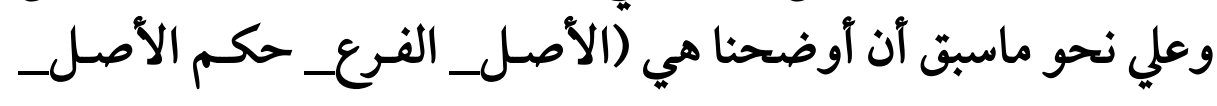


العلة) فإن أركان الرجوع إلي القاعدة العامة هي (الأصل المرجوع إليهـ

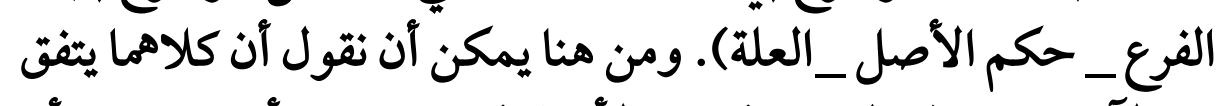

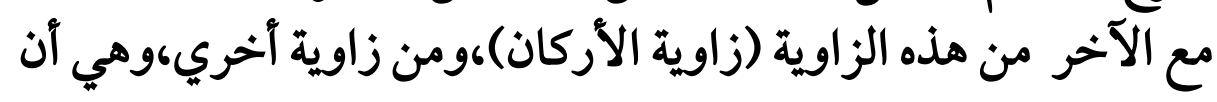

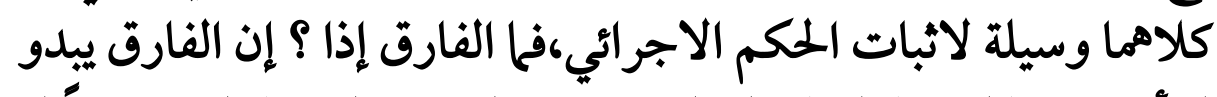

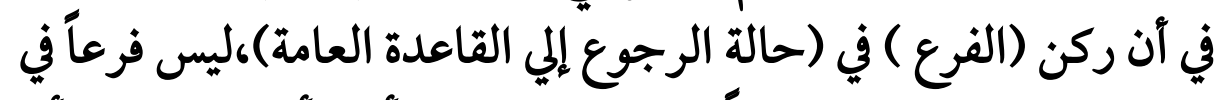

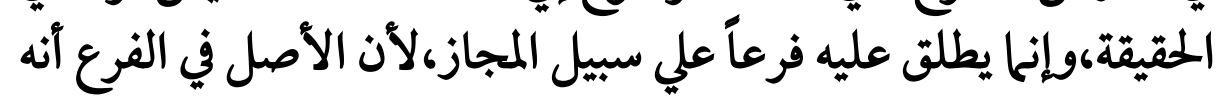

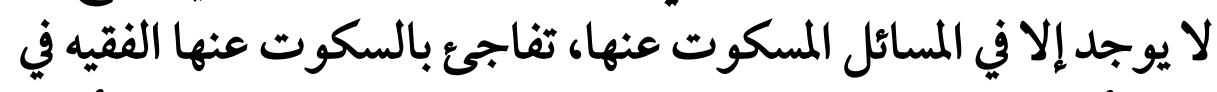

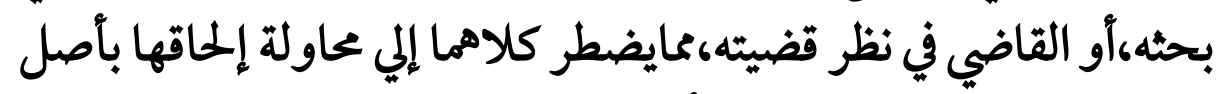

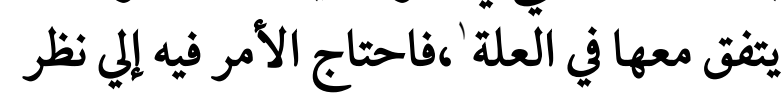

1 _ كأن ييد القاضي نفسه أمام طعن بالبطلان علي حكمبابسبب كتابة مسودته

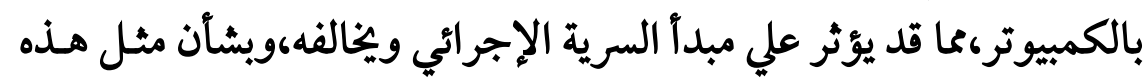

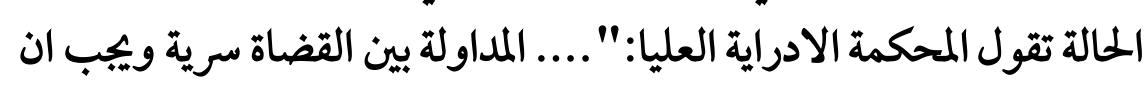

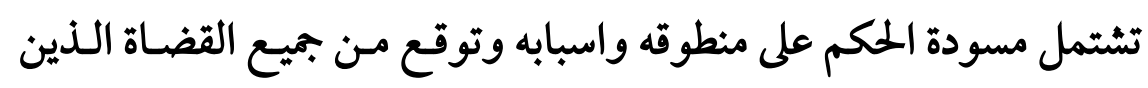

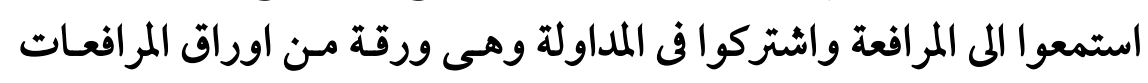

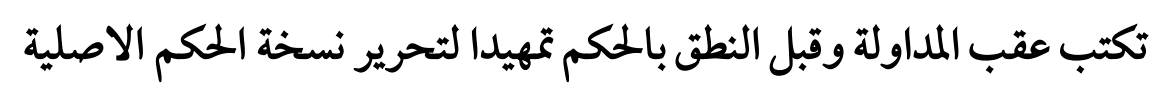

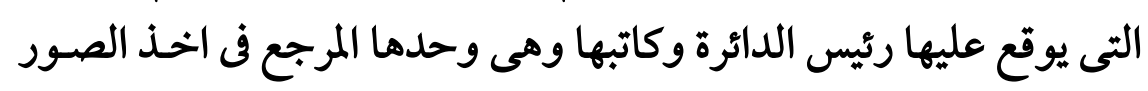

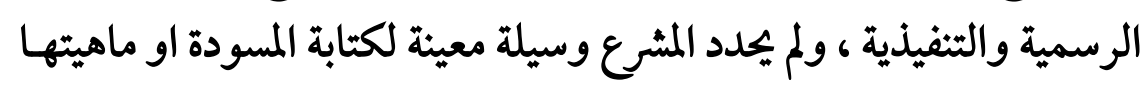

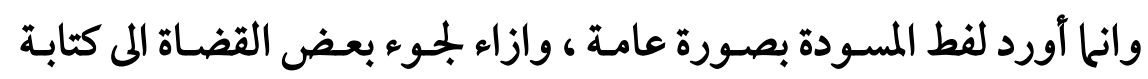

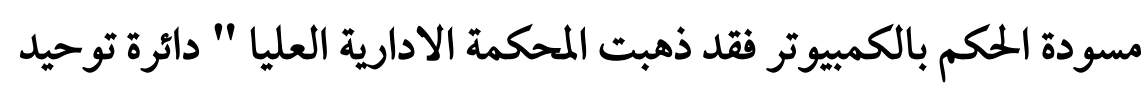

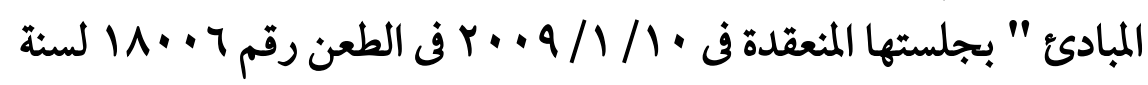

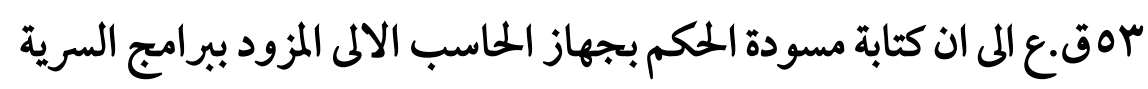




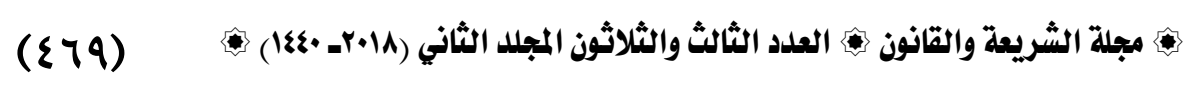
وتأمل 'أما الفـرع في حالة (الرجـوع إلي القاعـدة العامـة) ،فلـم

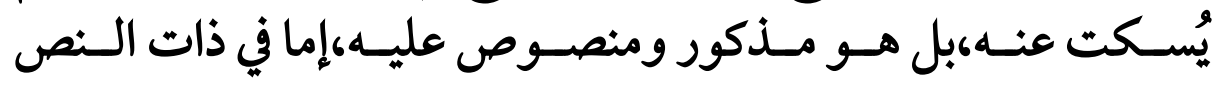

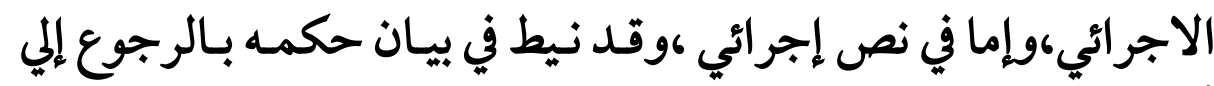

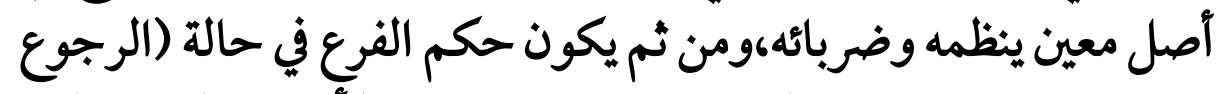

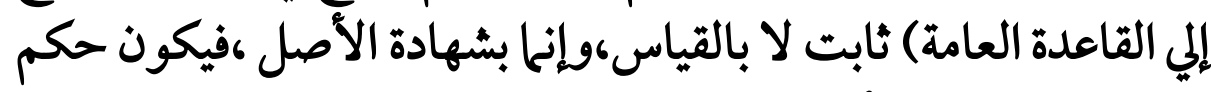

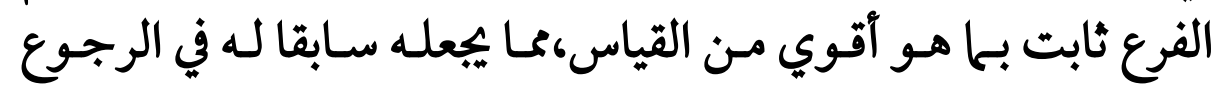

تحول دون اتصال الغير، والوضوح او استرجاع مـا دونه القـاضى بمسـودة

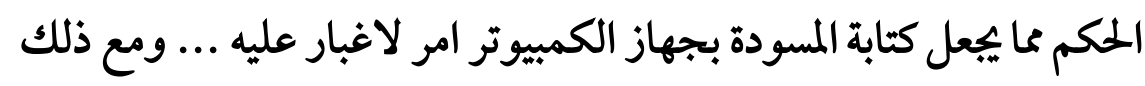

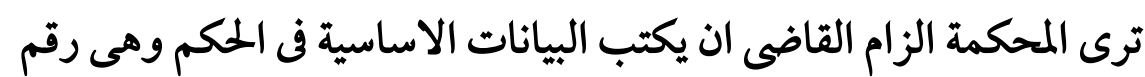

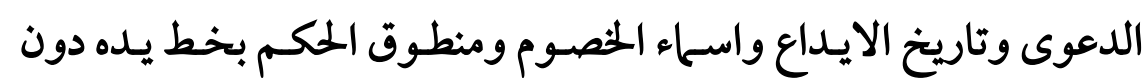

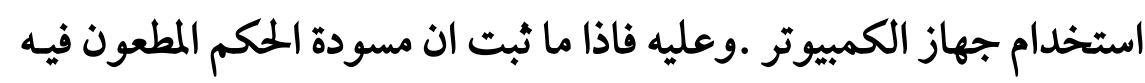

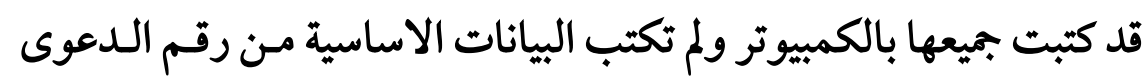

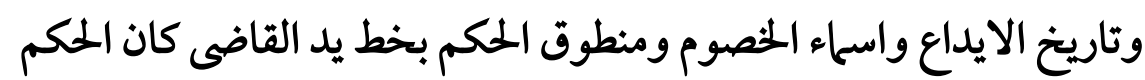

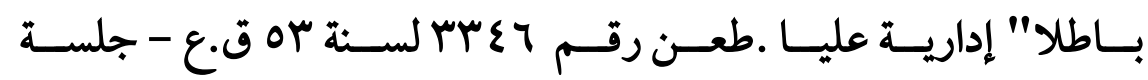
م. $1 \cdot / r / 1 r$ 1 _ـومن هنا يري فريق من الفقه الإسلامي آن المفهوم مـن فهـم فحوي النص

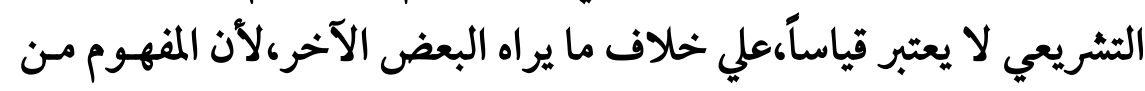

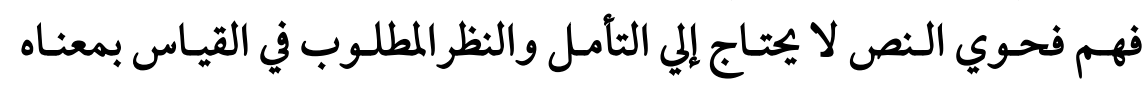

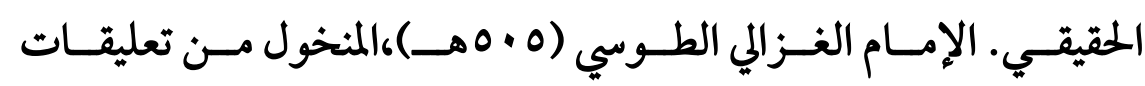

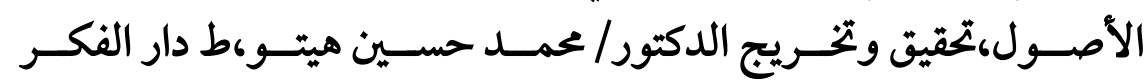

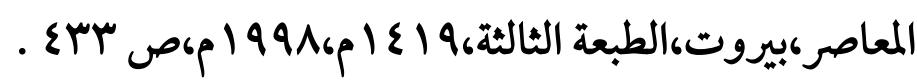




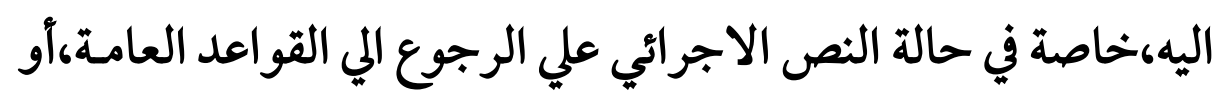

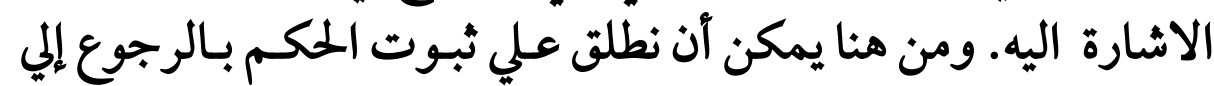

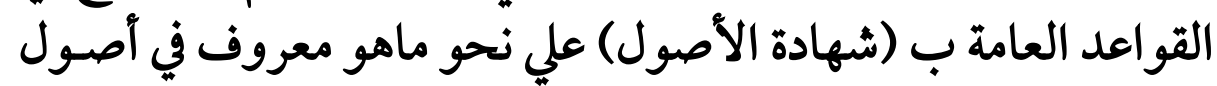

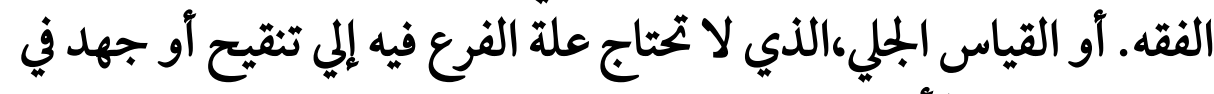

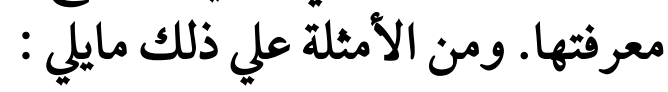

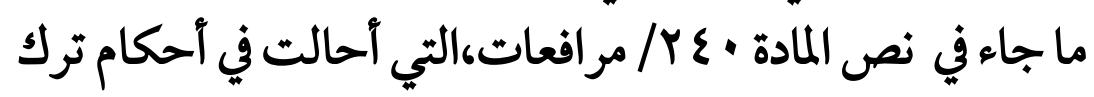

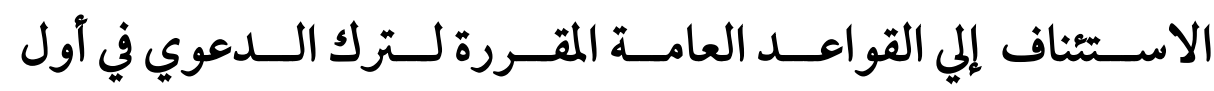

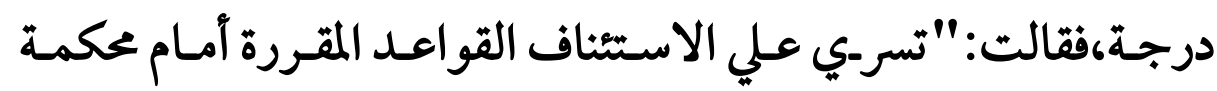

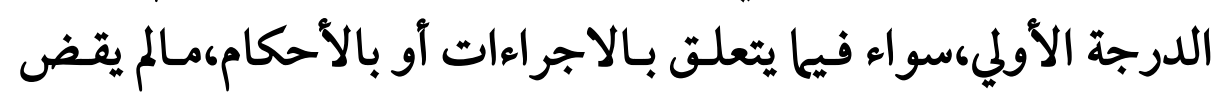

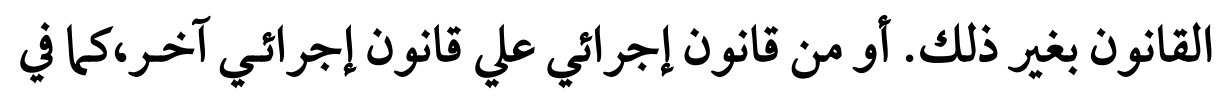

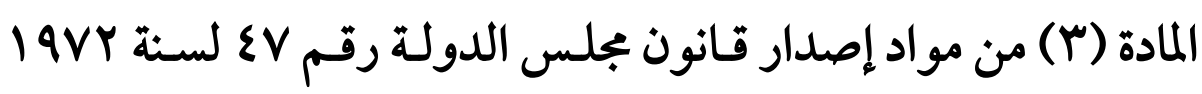

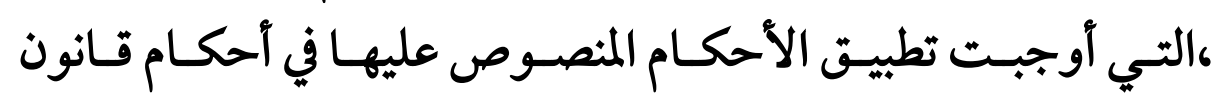

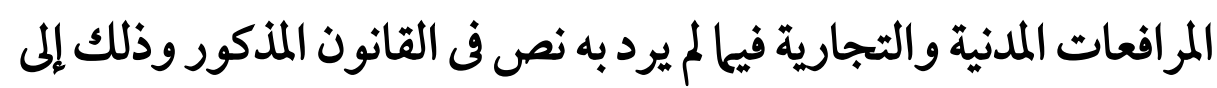

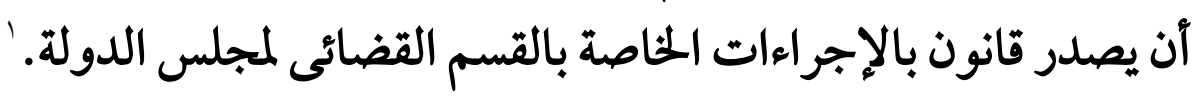

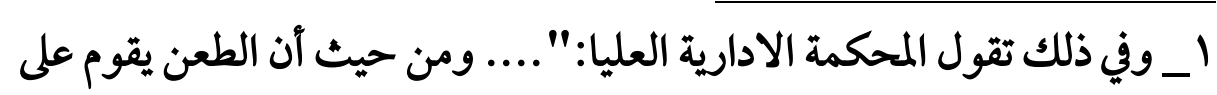

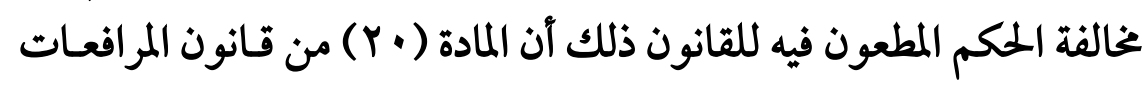

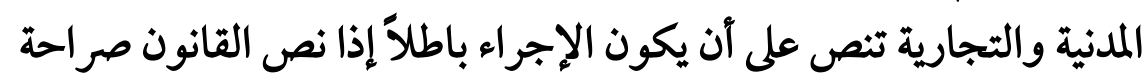

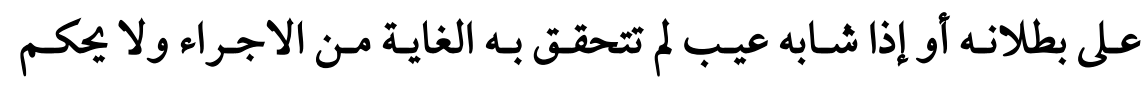

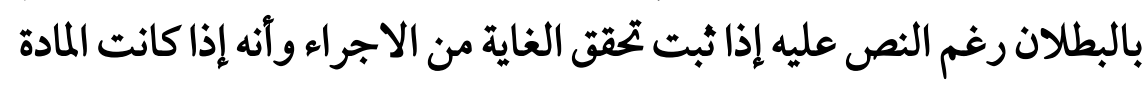

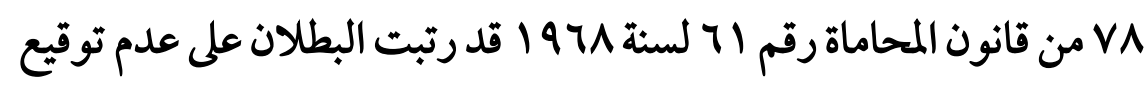




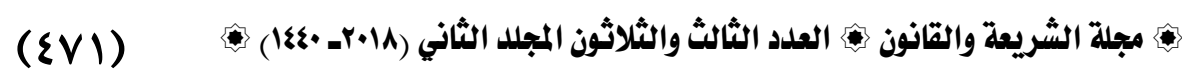

محام مقبول للمرافعة أمام محكمة الاستئناف على صحيفة الاستئناف، إلا آن

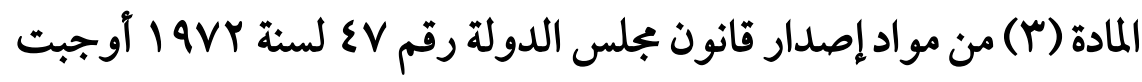

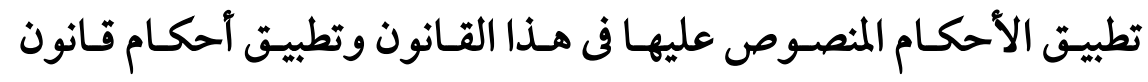

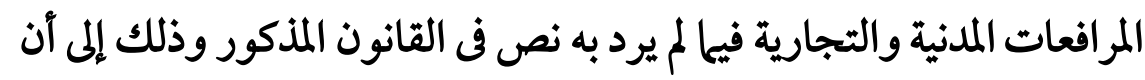

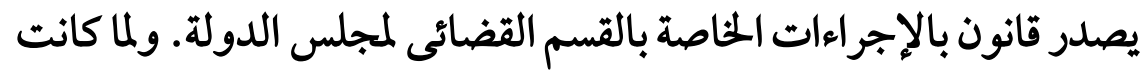

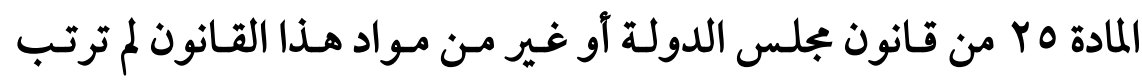

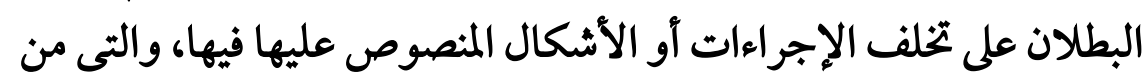

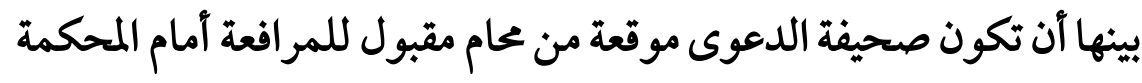

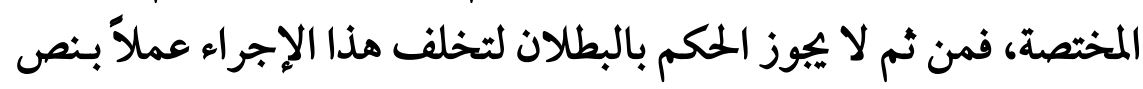

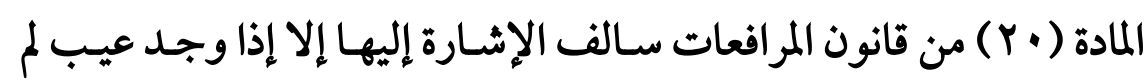

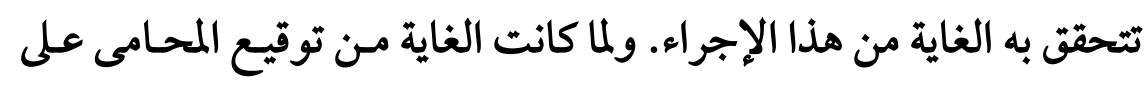

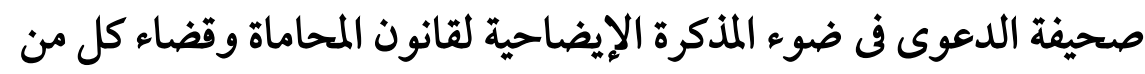

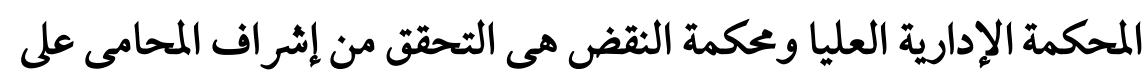

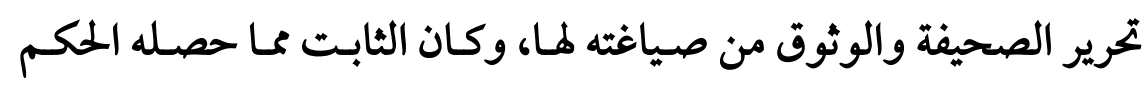

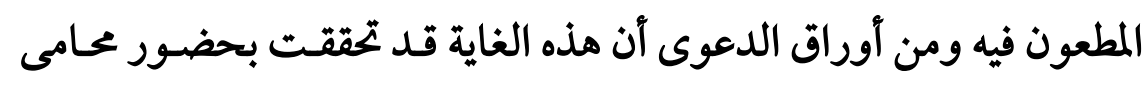

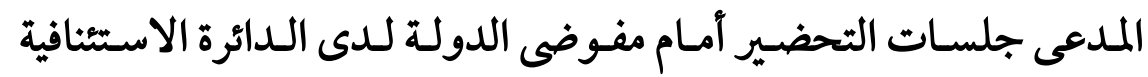

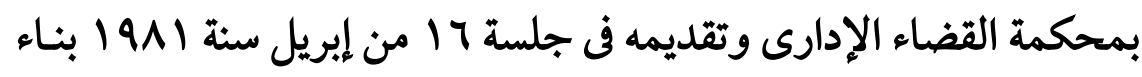

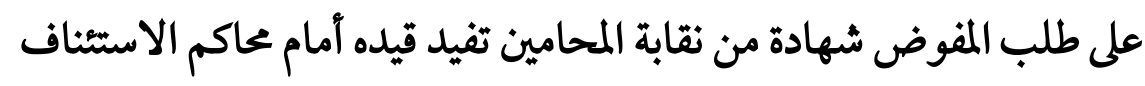

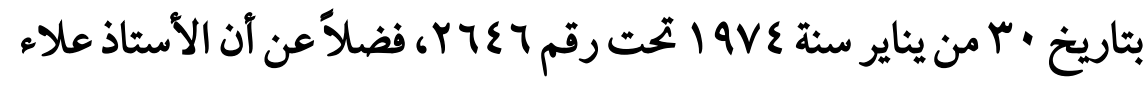

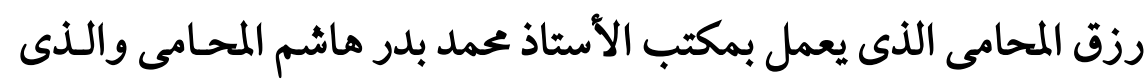

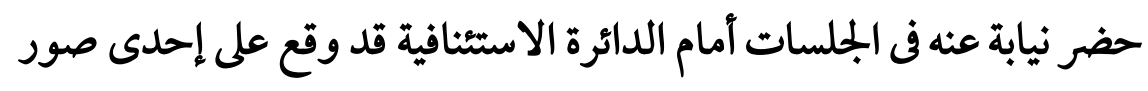




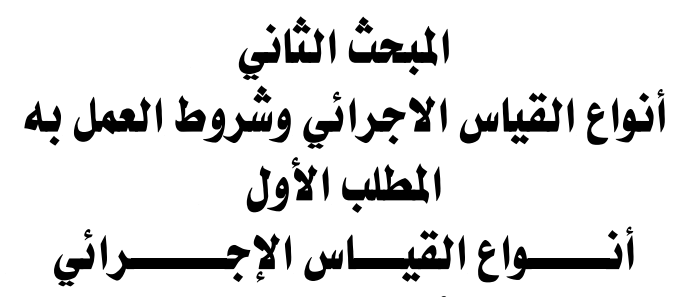

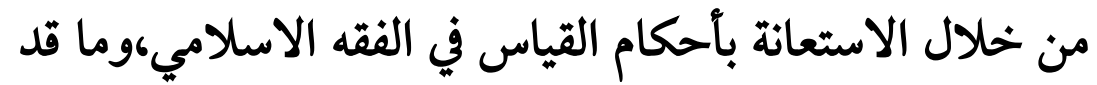

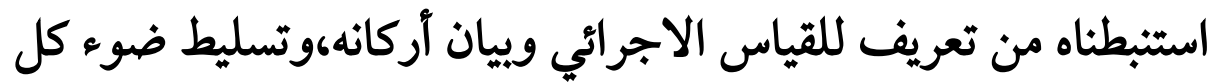
هذا علي نصوص القانون الاجرائي ،يمكن أن نقسم القياس الاجرائي

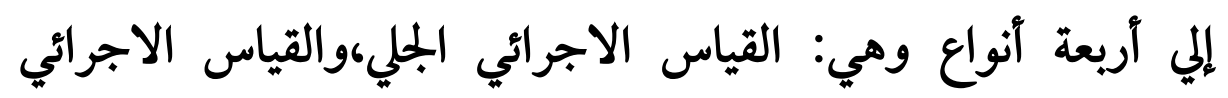
الخفي،وقياس الشبه،وقياس العكس،علي التفصيل الآتي : الفرع الأول_القياس الاجرائي الجلي

عريضة الاستئنف، وكان من قبل ذلك قد باشر الدفاع عن الطاعن أمام

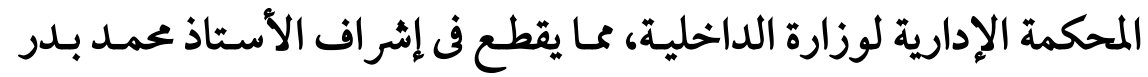

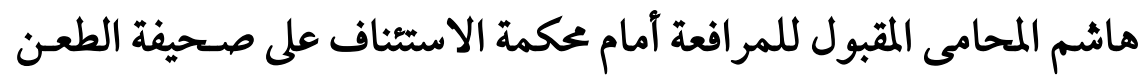

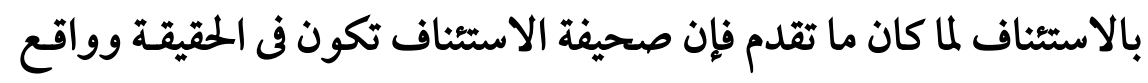

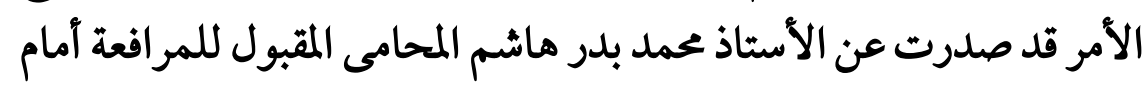

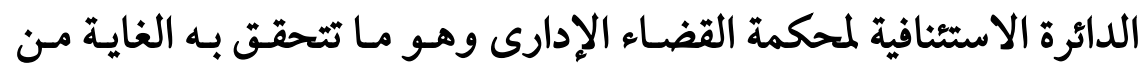

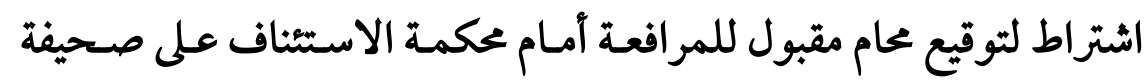

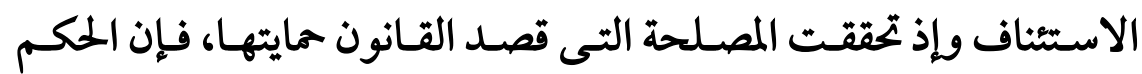

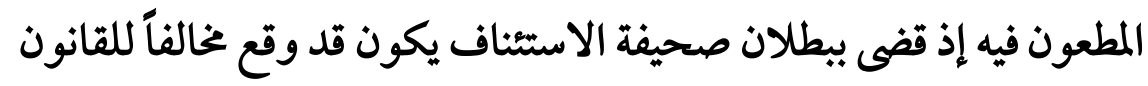

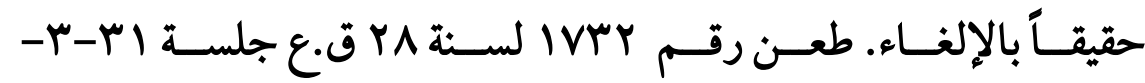

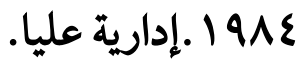




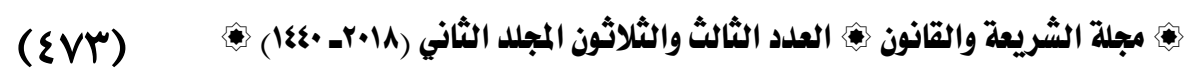

وهو مائبت علة الفرع فيه بالنص،كأو كان مقطوع فيه بنفي

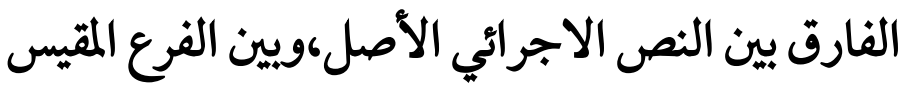

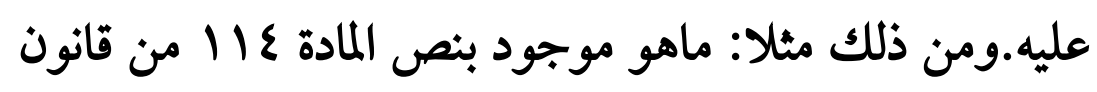
المرافعات ،والتي قاس فيها المشرع حالة إيداع المعلن إليه لمذكرات

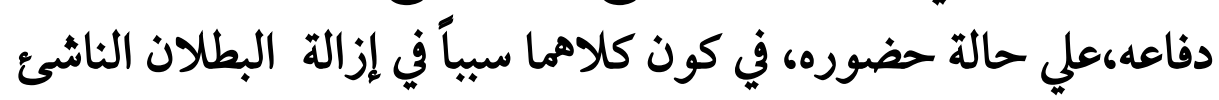

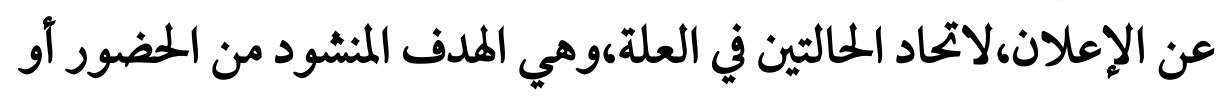

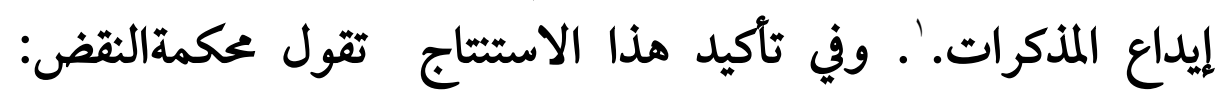

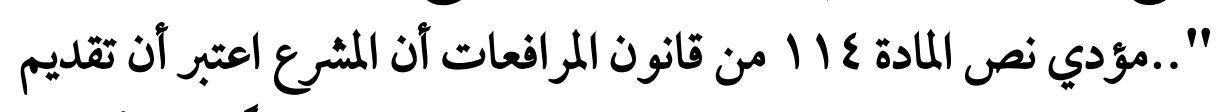
الخصم مذكرة بدفاعه يعد بمثابة الحضور بالجلسة اتساقاً مع ماأوردته

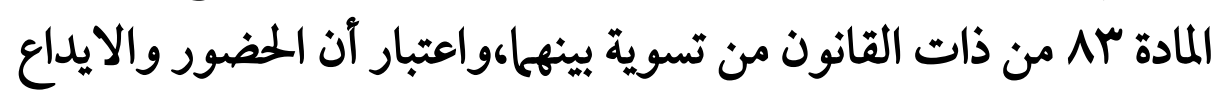

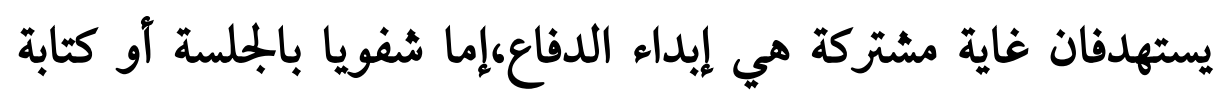

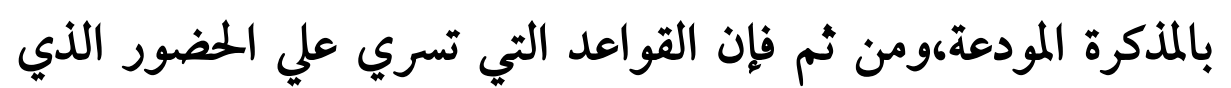

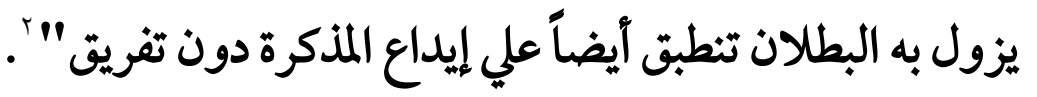
الفرع الثاني_القياس الخفي

|_ إذ تنص المادة ع || من قانون المرافعات علي :"..بطلان صحف الدعاوي

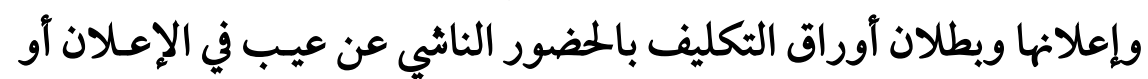

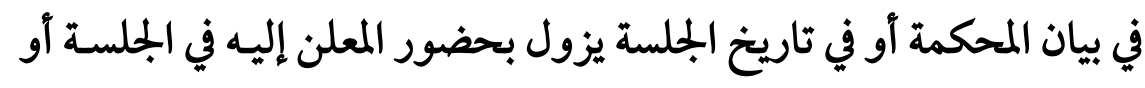
بإيداع مذكرة بدفاعه.

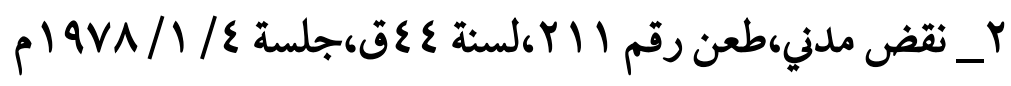


وهوماثبتت علته بالاستباط ،ولم يقطع فيه بنفي الفارق بين

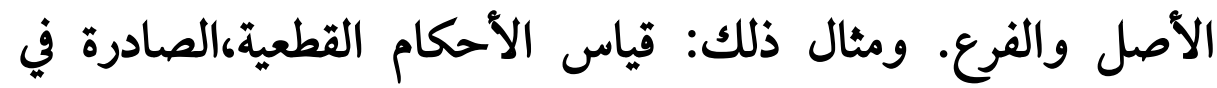

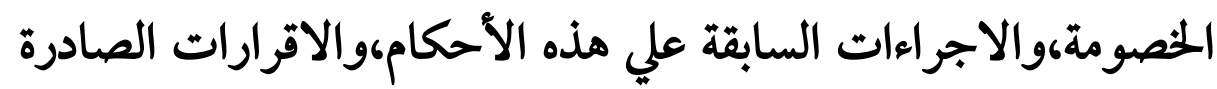

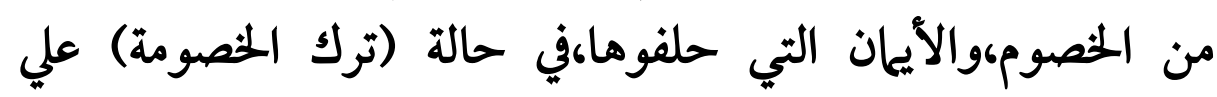

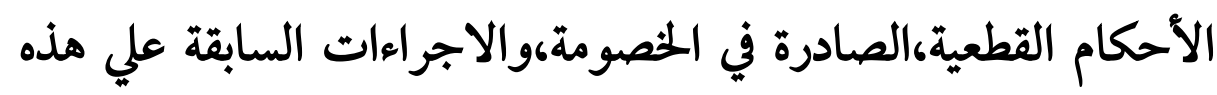

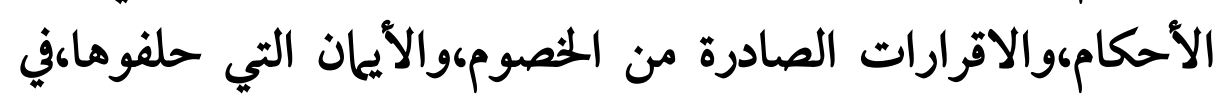

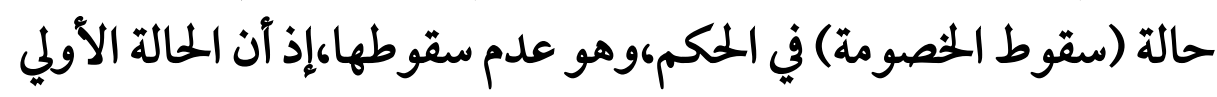

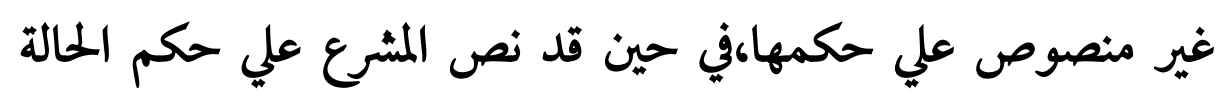

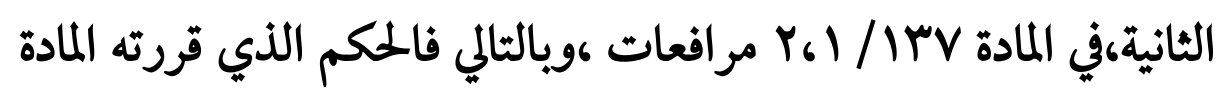

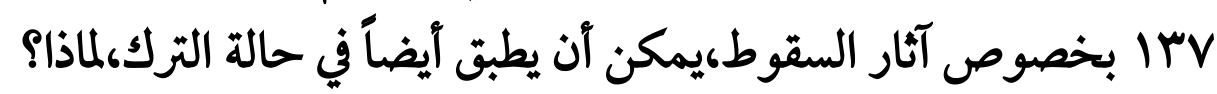

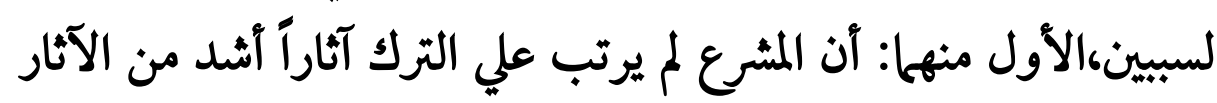

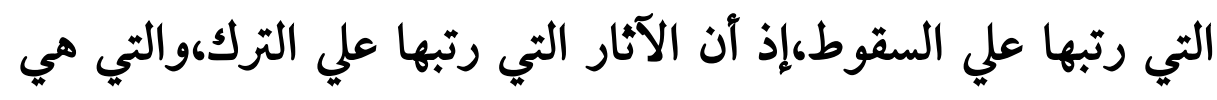

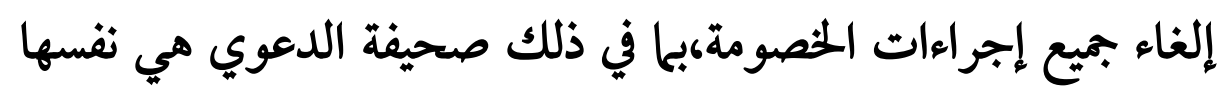

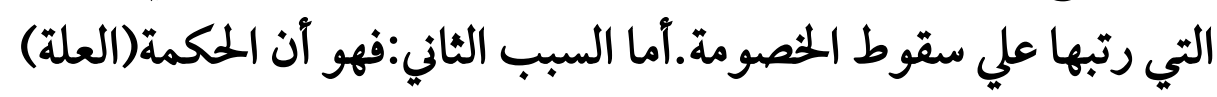

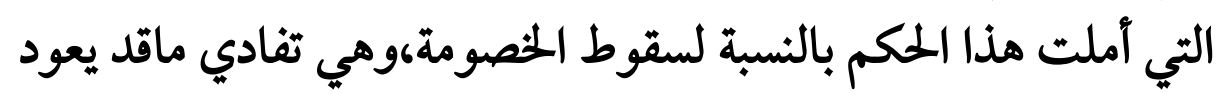

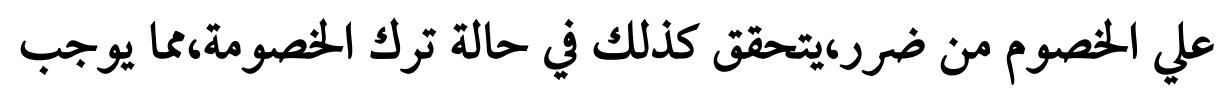

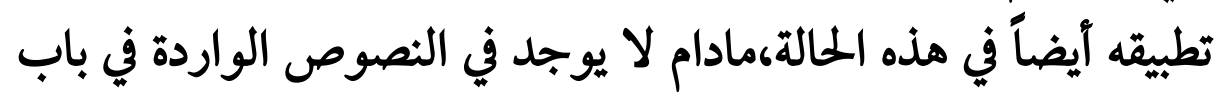
ترك الخصومة مايمنع تطبيقه الفرع الثالث_قياس الشبه الاجرائي 


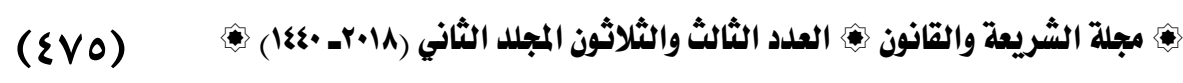
وهو القياس الذي يتردد فيه الفرع المسكوت عنه بين أصلين

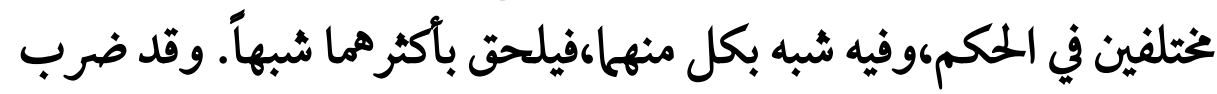

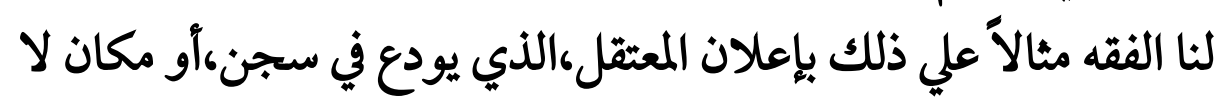
يعرف علي وجه القطع في أس سجن هو (كفرع إجرائي لم ينص علي

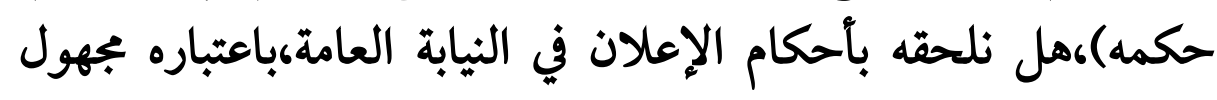

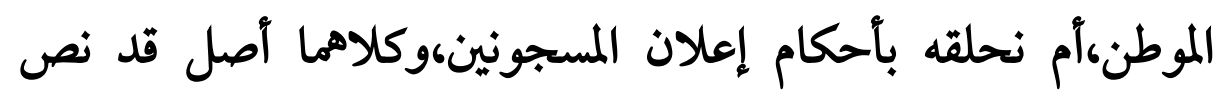
القانون علي حكميها ؟واختار هذا الجانب من الفقه إلحاقه بأحكام

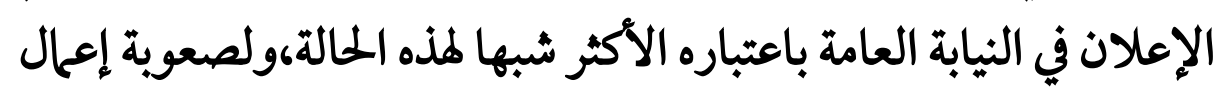

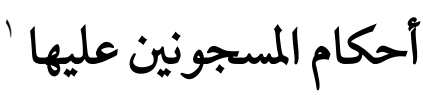

$$
\text { الفرع الرابع_ قياس العكس الاجرائي }
$$

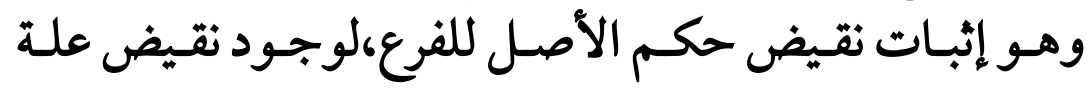

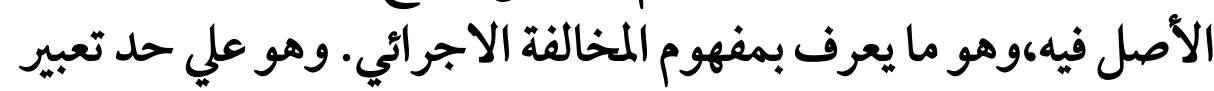

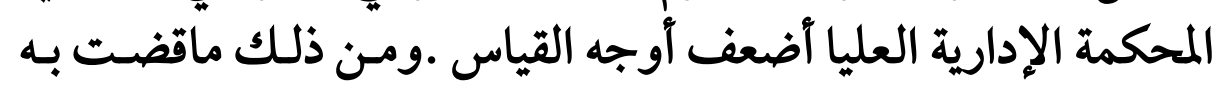

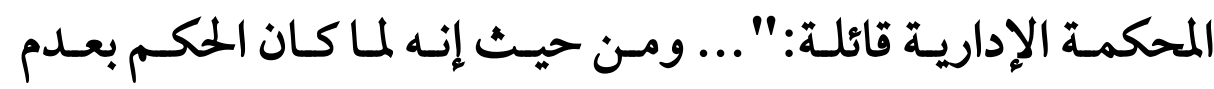

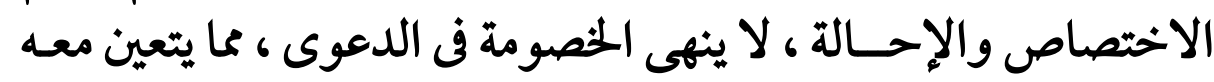

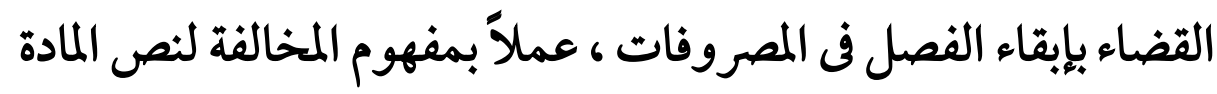

1_أ.د/ أمد هندي،قانون المرافعات المدنية والتجارية،المرجع السابق،ص ror 


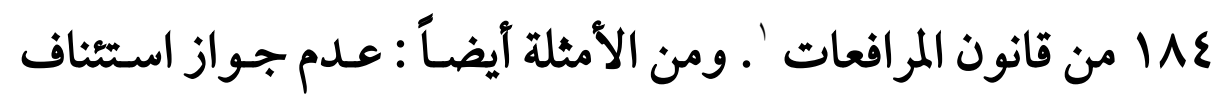

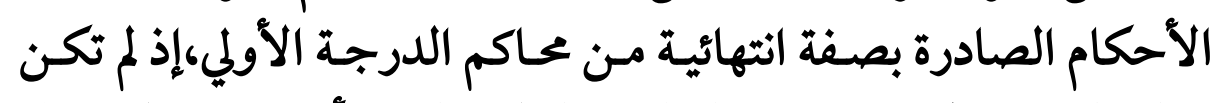

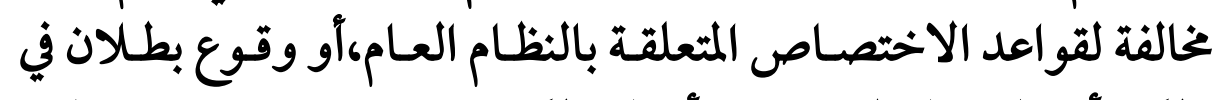

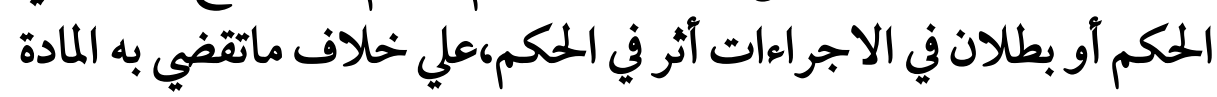

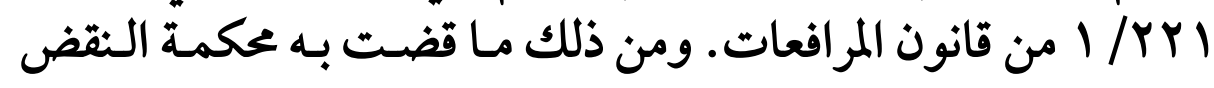

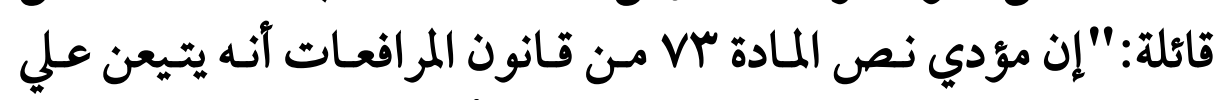

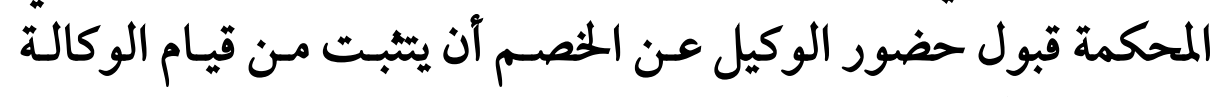

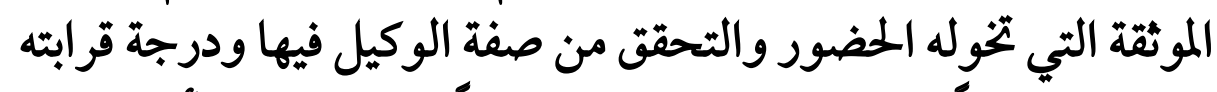

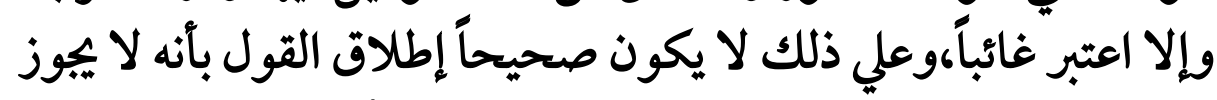

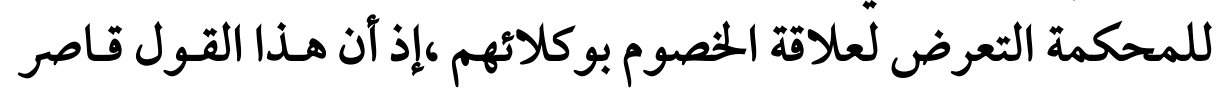

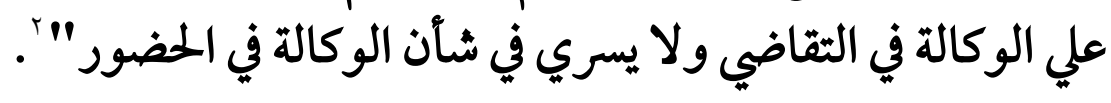

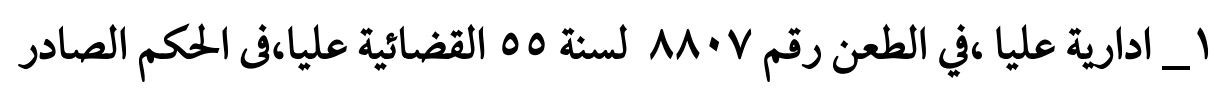

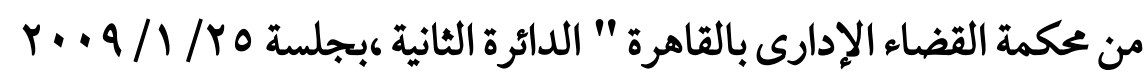

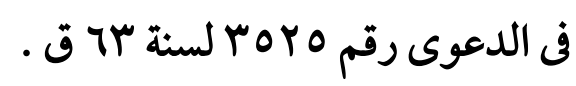

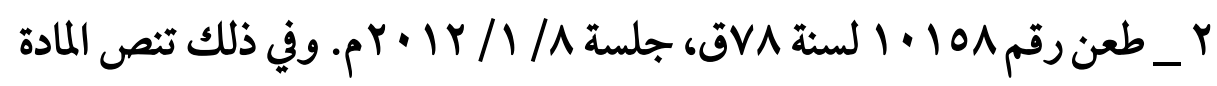

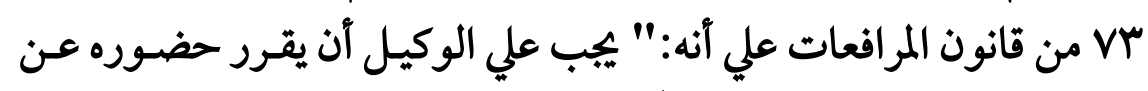

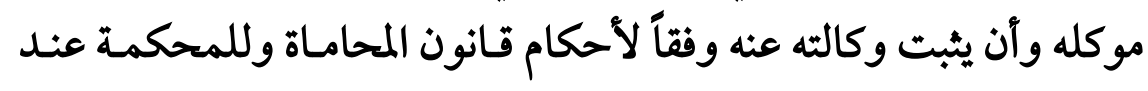

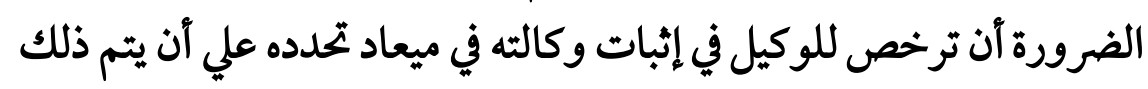

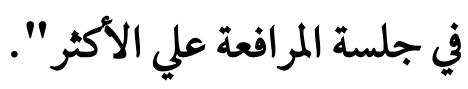




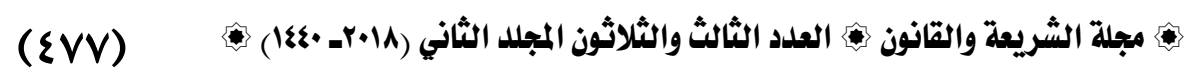

$$
\text { الفرع الخامس: القياس الاجرائي الفاسد }
$$

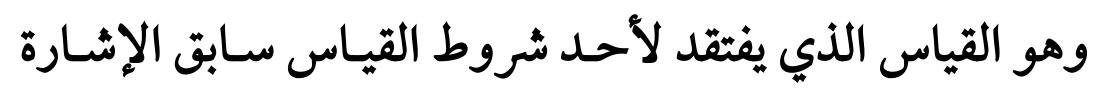

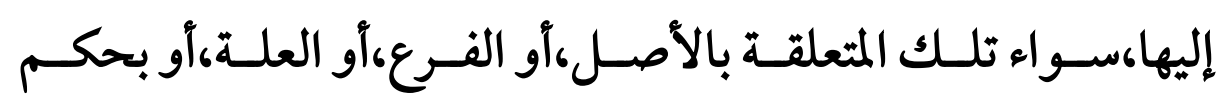
الأصل،كأن يقاس الفرع علي آصل له حكم خاص به (غير قابل للتعدي

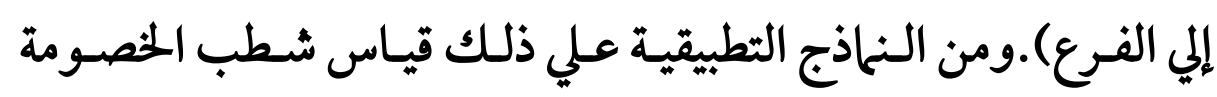

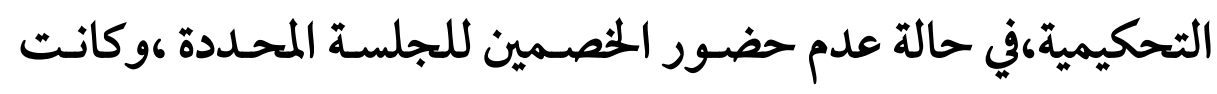

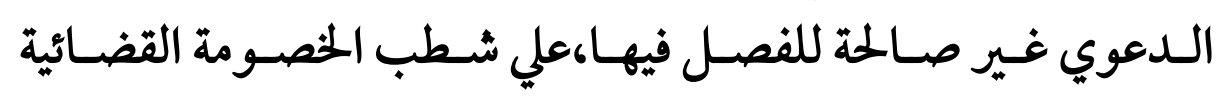

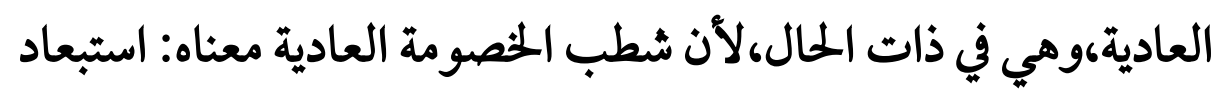

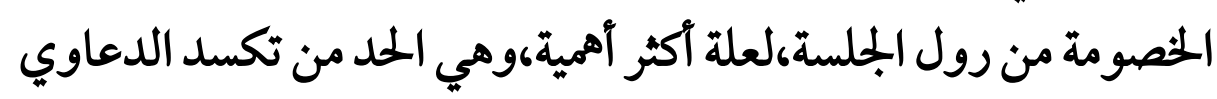
أمام المحاكم،وهذه العلة غير متصورة في حالة الخصومة التحكيمية. 


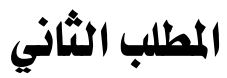 \\ شروط العمل بالقياس الاجرائي}

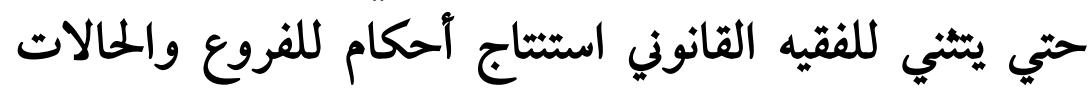

الاجرائية،التي قد تطرأ علي الساحة العملية بالقياس (كأمارة قانونية)'

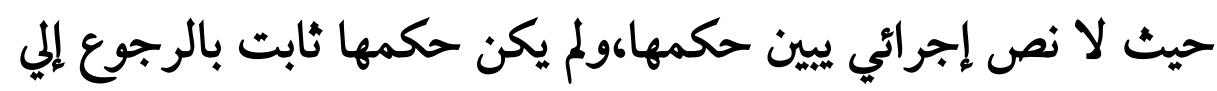

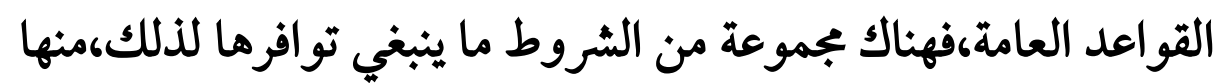

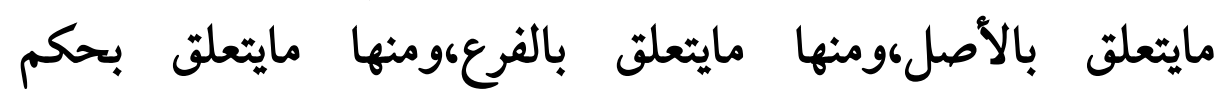
الأصل،ومنها مايتعلق بالفرع،وذلك علي النحو النهو الآتي بيانه :

الفرع الاول_الشروط المتعلقة بالأصل (المقيس عليه)

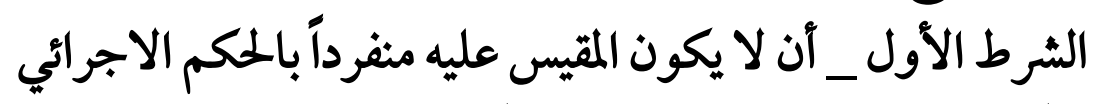

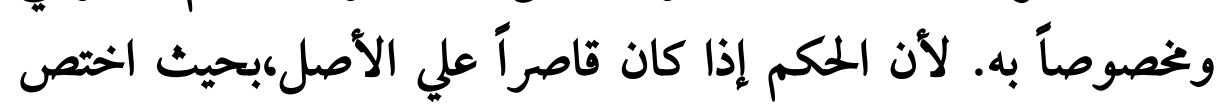

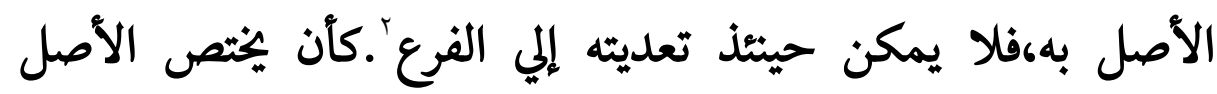

1 ـ يَيِمّم الفقه الاسلامي القياس بالأمارة ،ويعتبرها أحد أدلة الأحكام الفقهية .

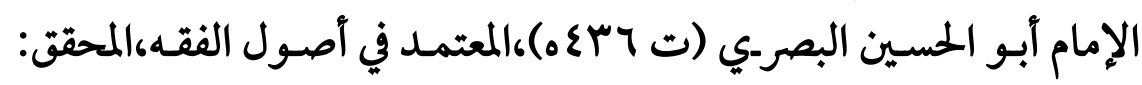

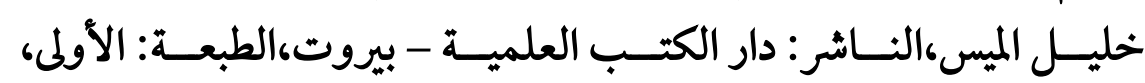

$$
\text { 1 1 }
$$

r__وقد عرف الفقه الإسلامي نموذجا قياسيا إجرائياً لذلك، ألا وهو اختصاص

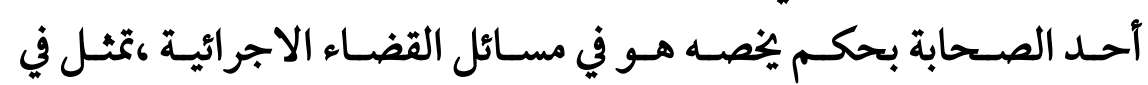

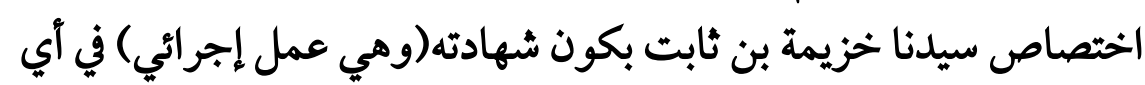

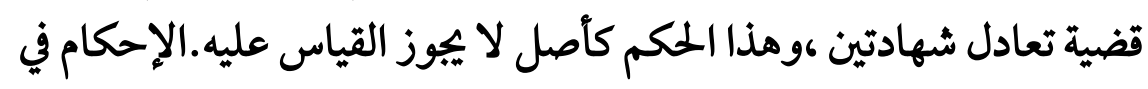




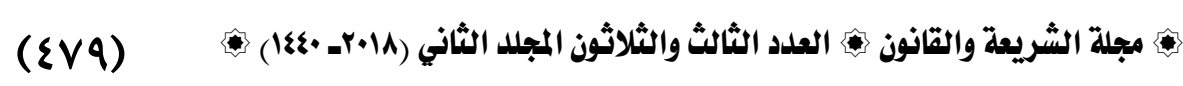

الاجرائي بحكم إجرائي علي سبيل الاستثناء مثالً...التنفيذ المعجل

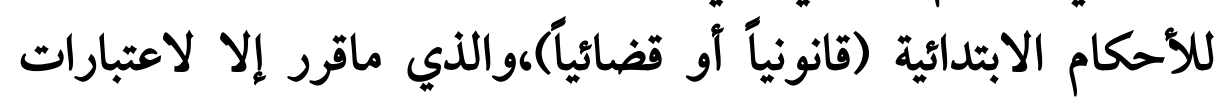

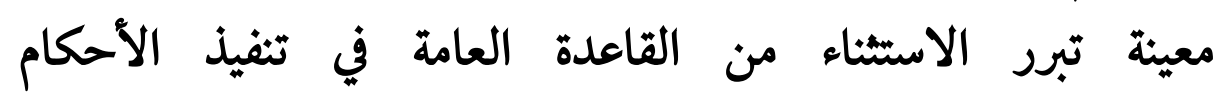

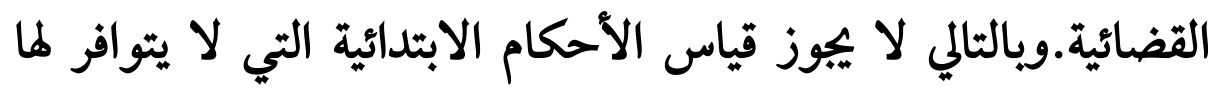

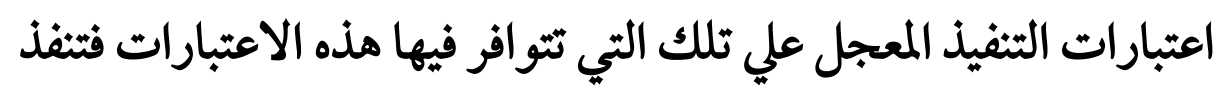

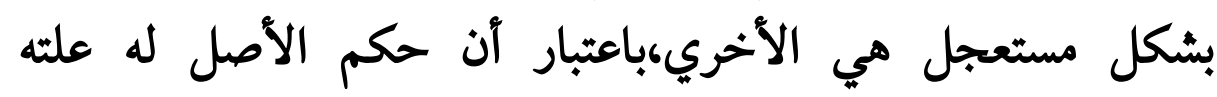
الخاصة،التي جعلته ينفرد بالحكم الاجري ائي،يختصاً به.

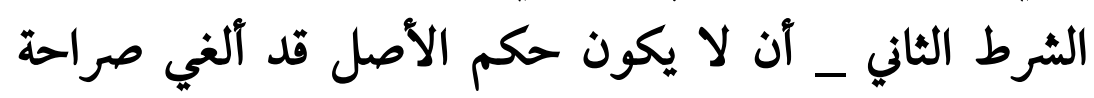
بالنص علي الإلغاء،أو ضمناً بصدور تشريع جديد ينظم ذات المسألة دون نص علي الإلغاء.ومن ثم إذا كان حكم الأصل ملغياً آو منسوخاً فلا

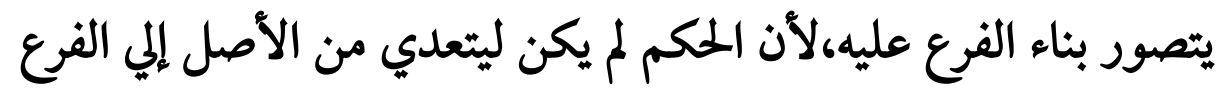
إلا بناءُ علي العلة الجامعة،وهذا الأمر متوقف علئ علي اعتبار المشرع لئه

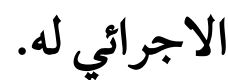

الشرط الثالث: أن لا يكون الدليل الاجرائي الدال علي إثبات

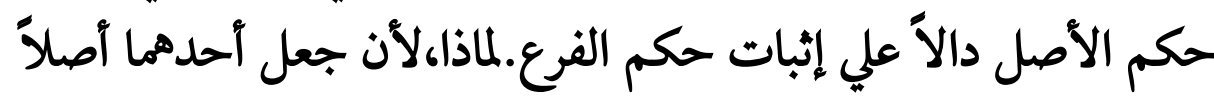

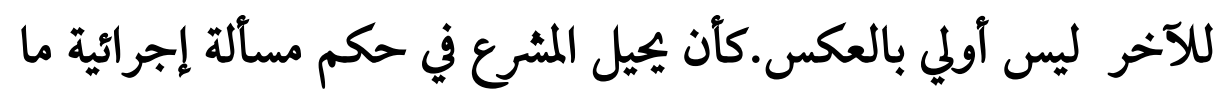
إلي نص إجرائي يتضمن حكمها.

أصول الأحكام، الآمدي (ا آד هـ)،تحقيق / عبد الرزاق عفيفي،ط المكتب

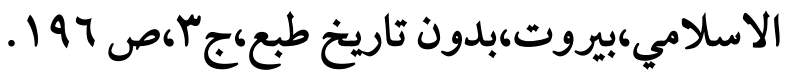


الشرط الرابع: آن لا يكون الأصل الاجرائي المقيس عليه فرعاً

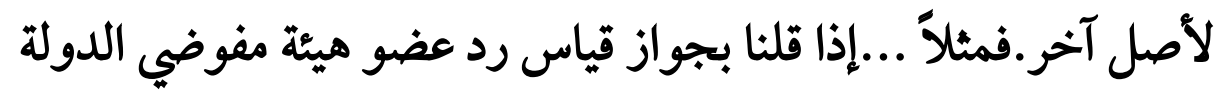

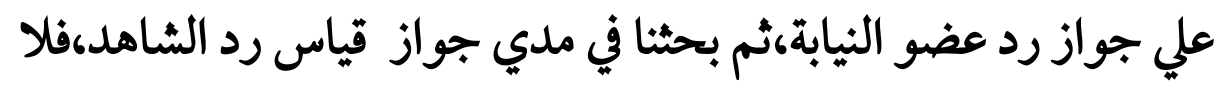

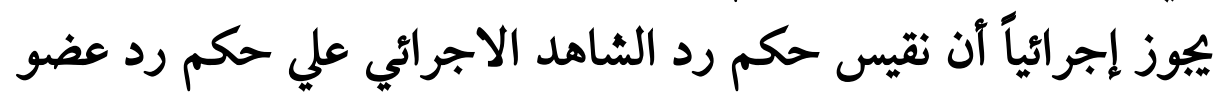

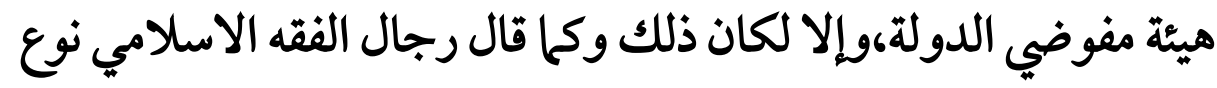
من تطويل الطريق الاجرائي وهو عبث '،وعيب لاييوز الفرع الثاني- الشروط المتعلقة بالفرع (المقيس) الثيس

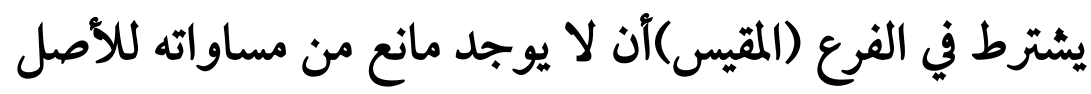

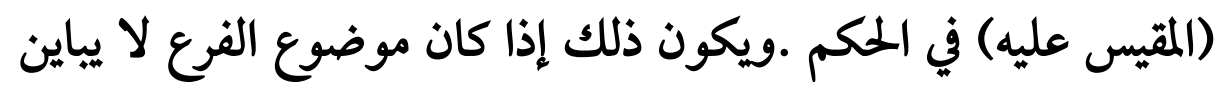

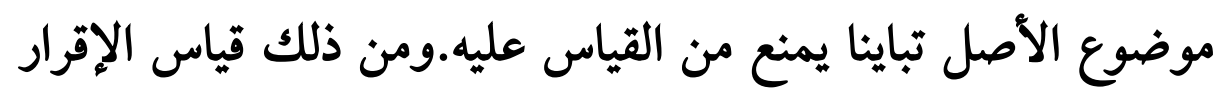

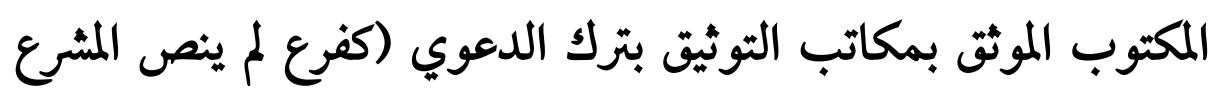

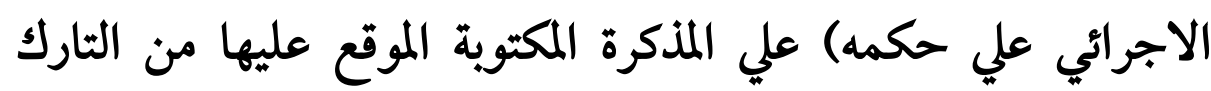

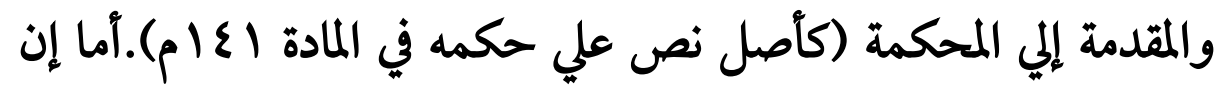

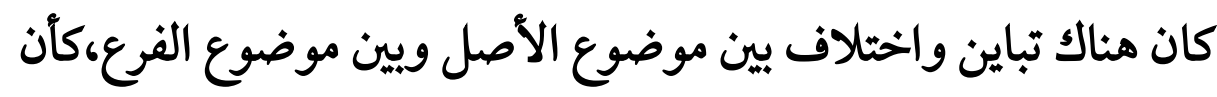

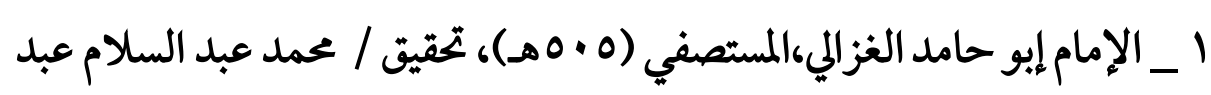

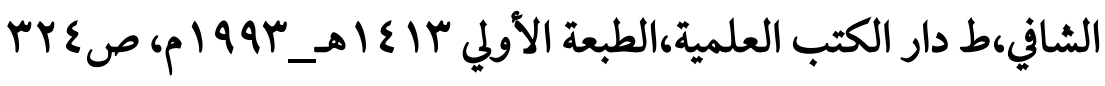

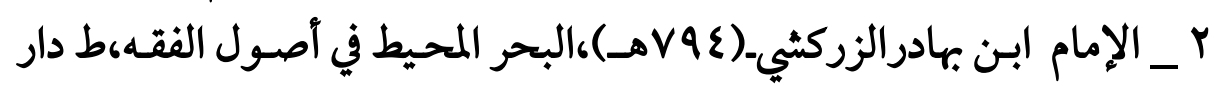

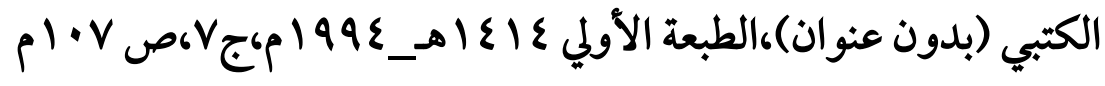




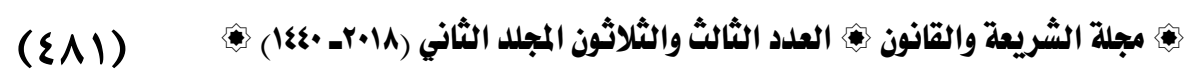
يكون حكم الأصل متعلق بآلية ترك الخصومة،وموضوع الفرع متعلق بآلية الطعن مثلا،فلا معني للقول بالقياس هنا.

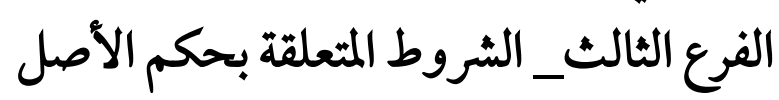
يشترط في حكم الأصل آن لا يكون الحكم مختصاً بالأصل

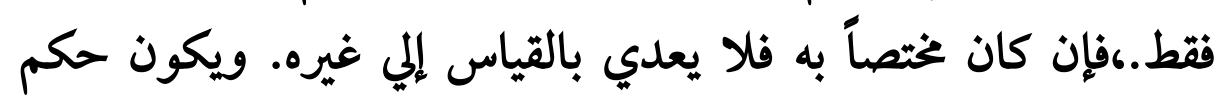

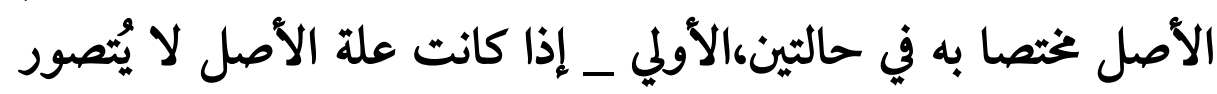
وجودها في غير الأصل. والثانية _ إذا وجد نص آلئي آخر (دليل إجرائي آخر) يدل علي تخصيص حكم الأصل به. ومن هنا يمكن القول بوضوح النه

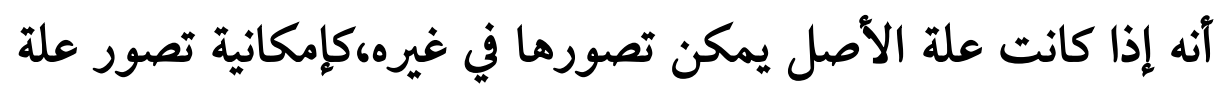

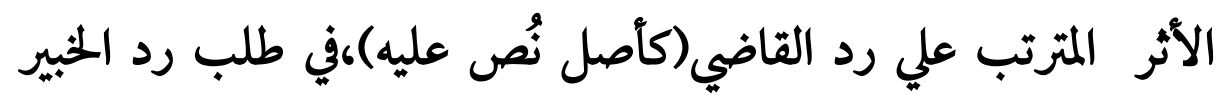

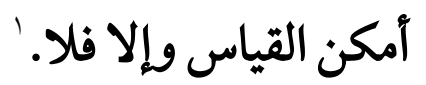

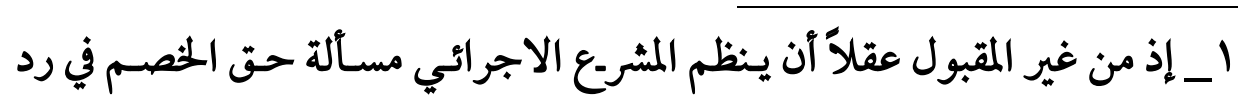

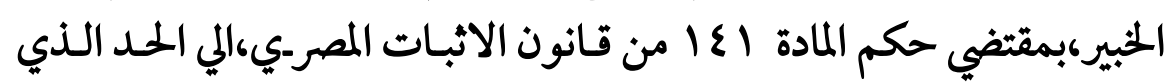

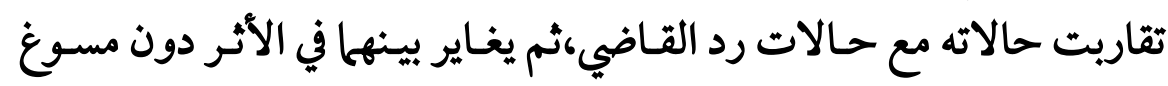

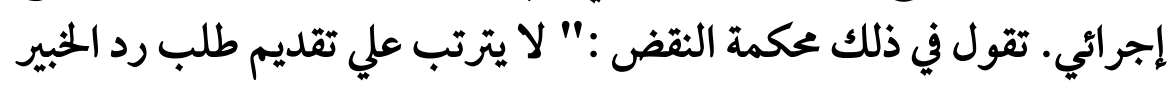

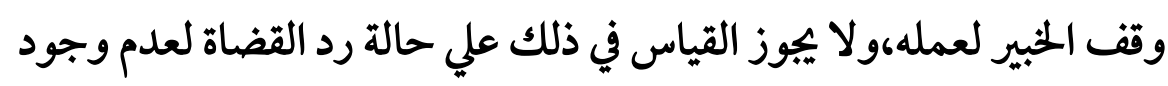

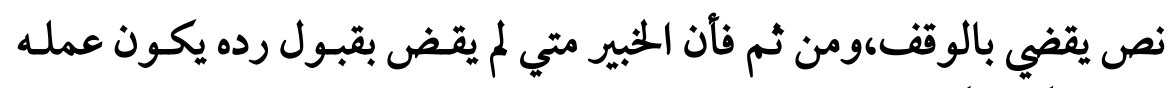

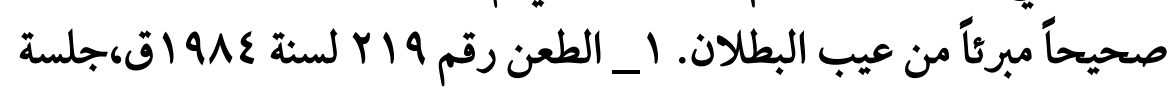

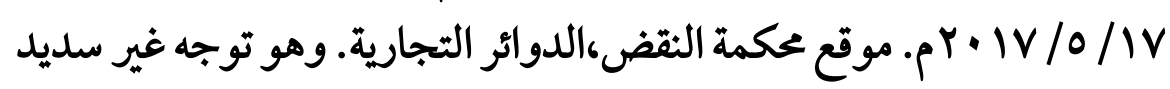
من محكمة النقض، لما أشرنا إليه. 
الفرع الرابع_الشروط المتعلقة بالعلة الشرط الأول _أن تكون العلة الاجرائية وصفاً ظاهراً

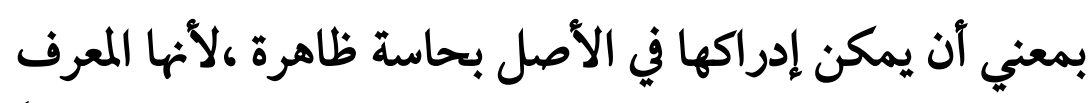

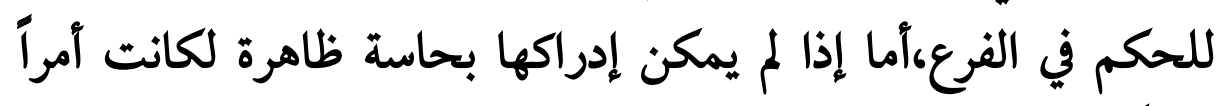

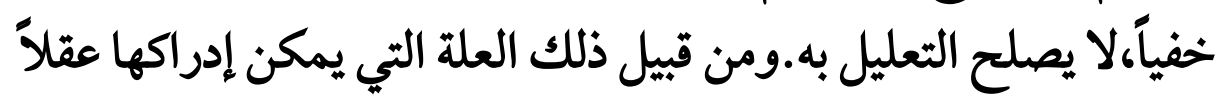

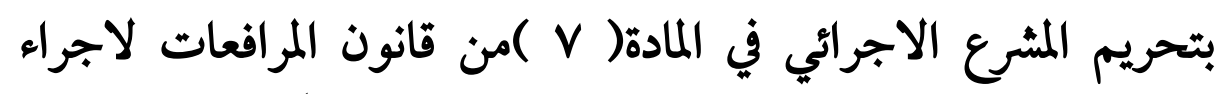

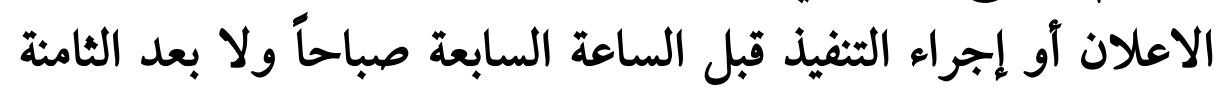

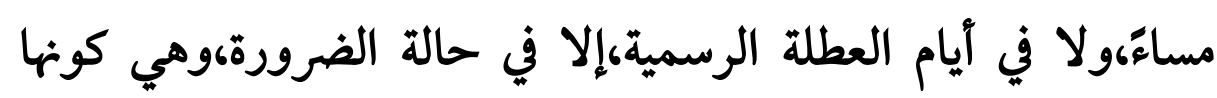

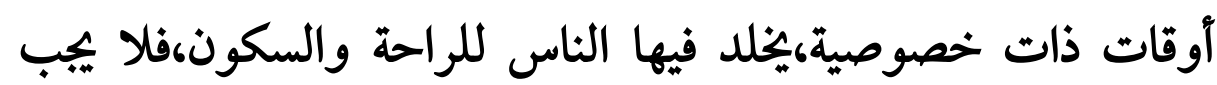

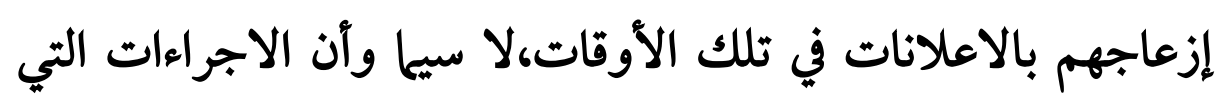

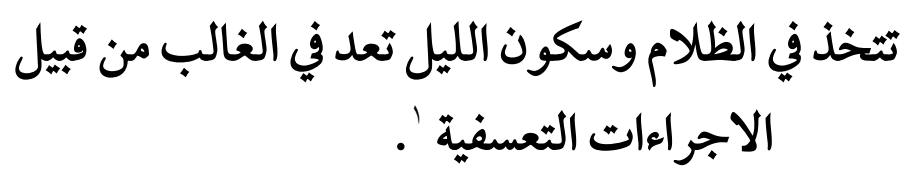

الشرط الثاني _آن تكون العلة وصفاً منضبطاً

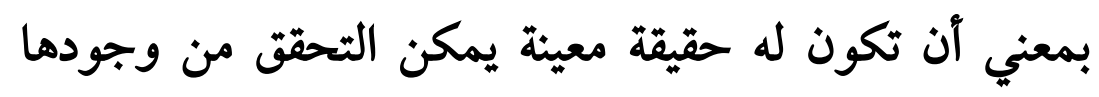

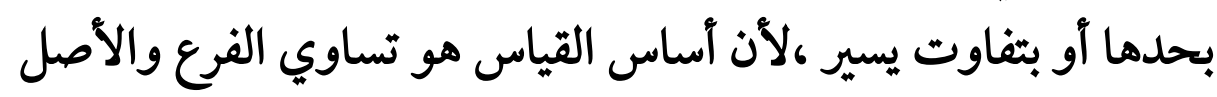

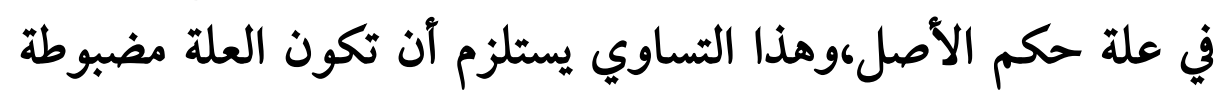

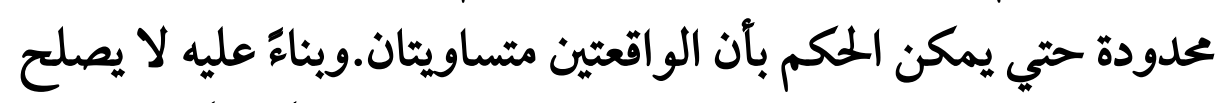

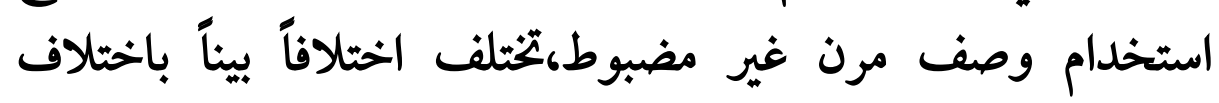

1_أ.د/ أمد هندي، قانون المرافعات، مرجع سابق، 11 البابند IN1. 


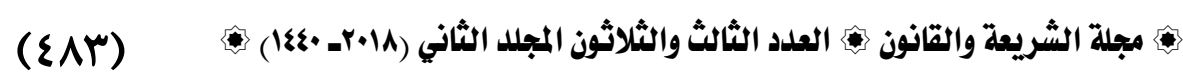

الظروف والأحوال والأفراد.فمثلا لو فتشنا عن العلة شبه الثابتة في إقرار

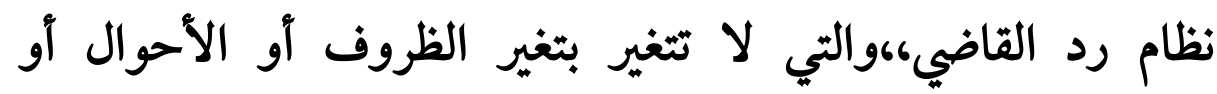

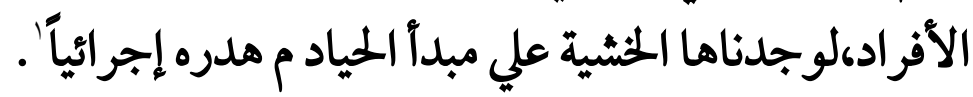
الشرط الثالث _ أن تكون العلة الاجرائية وصفاً مناسباً

ومعني مناسبتة الوصف،أن يغلب علي الظن مناسبة هذه العلة

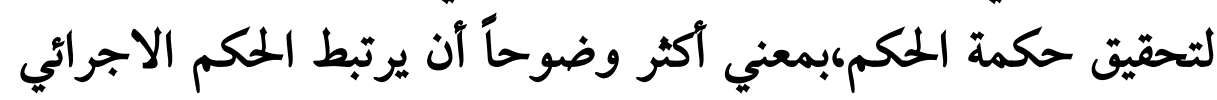

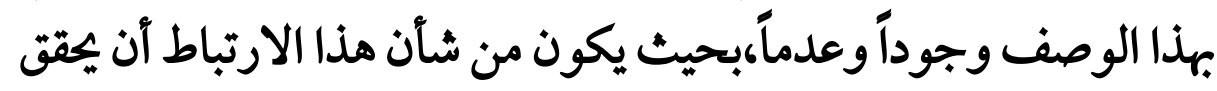
ماقصده المشرع الاجرائي من مقصد إجرائي،إذ أن الباعث الحقيقي علي

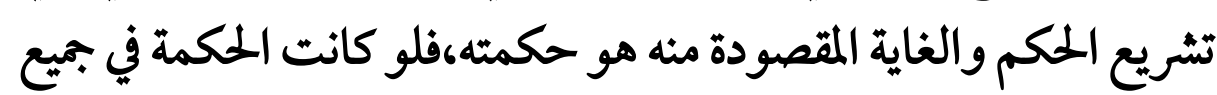
الأحكام ظاهرة ومضبوطة،لكانت هي علل الأحكام،لأنها الباعثة علي تشريعها.ولكن لعدم ظهورها في بعض الأحكام وعدم انضباطها في ومغي

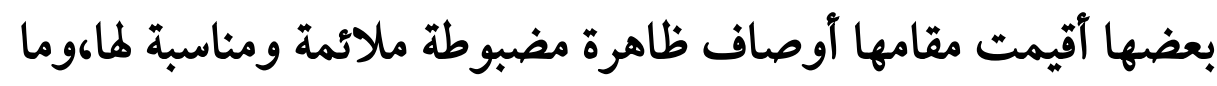

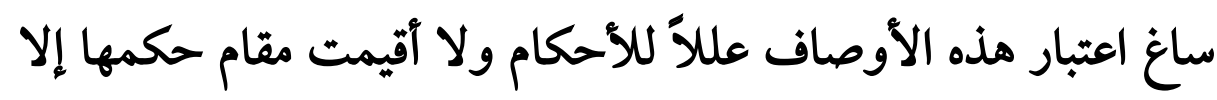

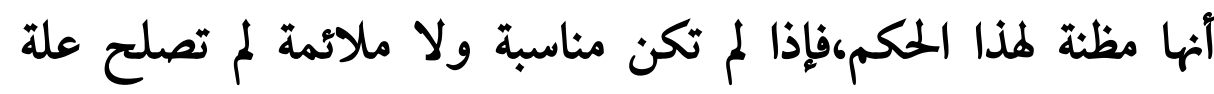

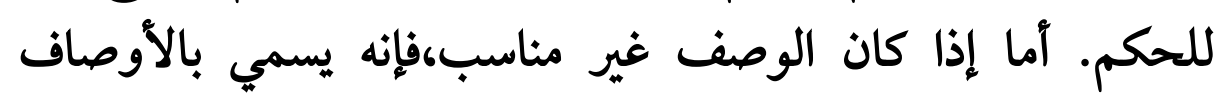

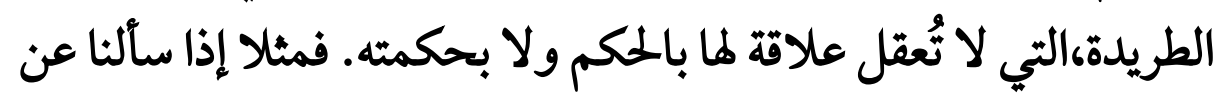

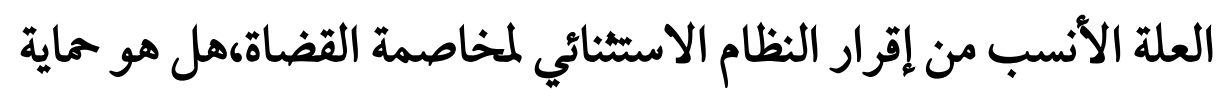

1_الحيدة تعني منع القاضي من إصدار أحكام عن تحيز وهوي.أ.د/ أحمد هندي،

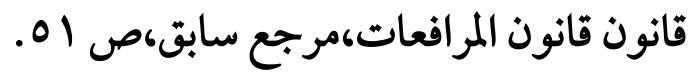


مبدأ الحيدة مثلاًا، أم أنه توفير الطمأنينة للقاضي في عمله وإحاطته بسياج

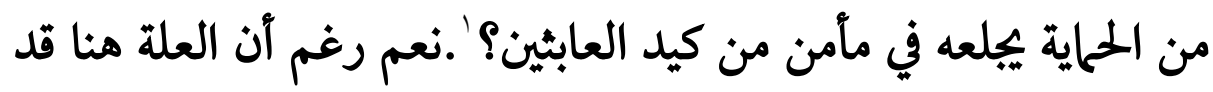

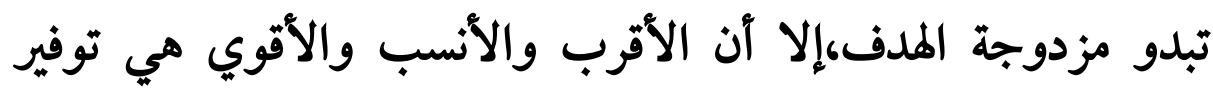

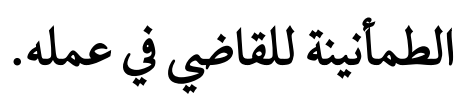
الشرط الرابع_أن لا تكون العلة وصفاً قاصراً علي الأصل.

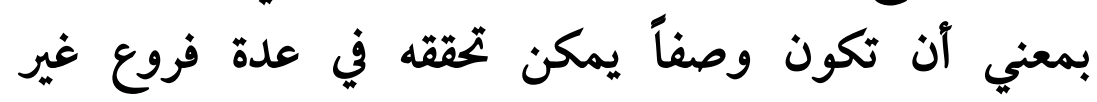

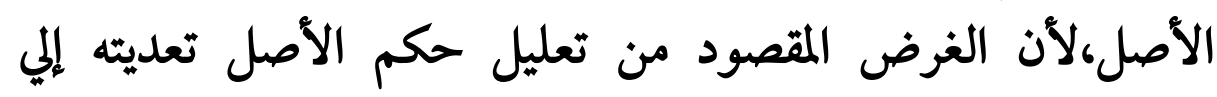

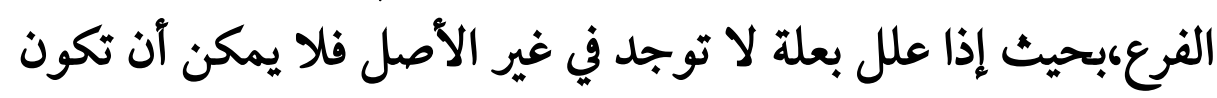

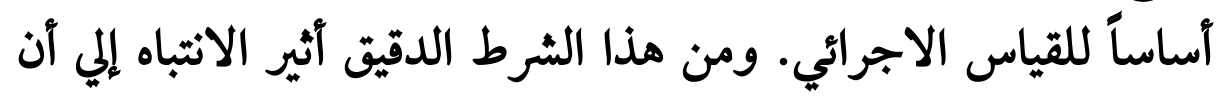

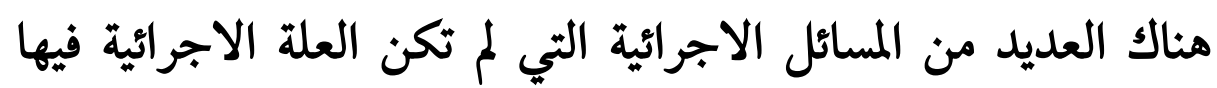

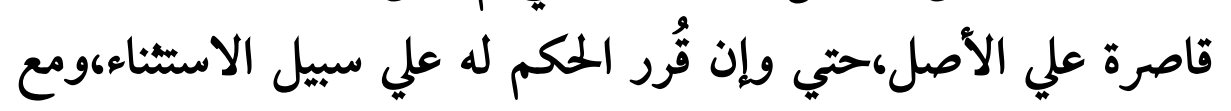

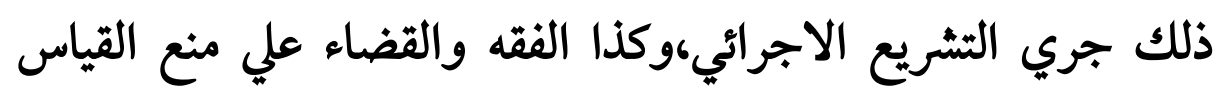

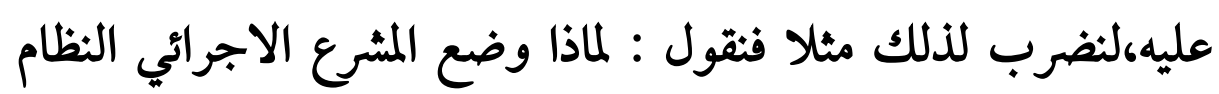

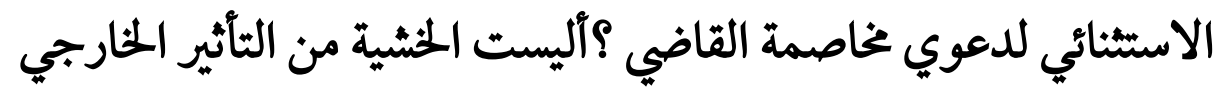

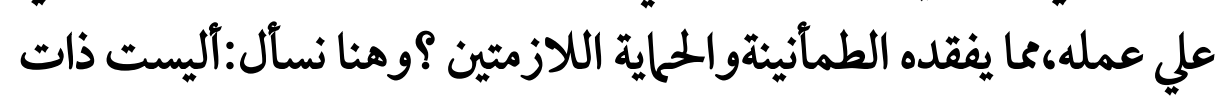

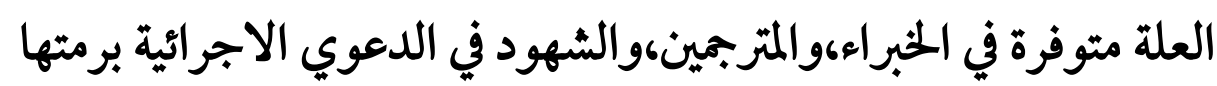

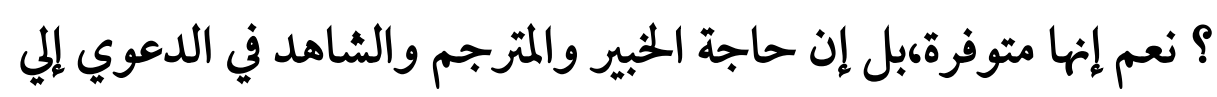

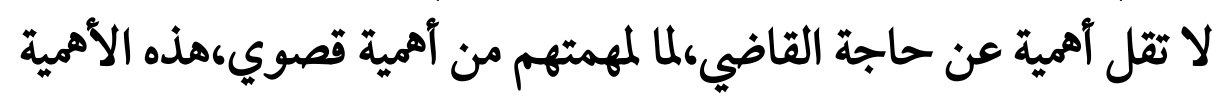

I _أ.د / أمد هندي، قانون المرافعات،مرجع سابق،ص Y Y 


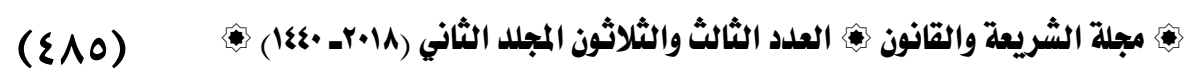
نابعة من القدرة علي التأثير في عمل القاضي نفسه تجاه نظرته

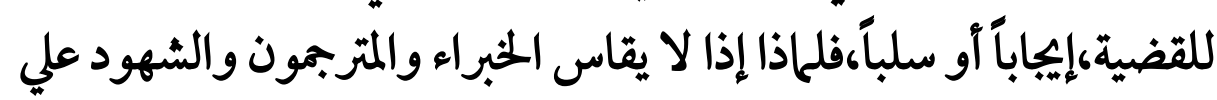
القاضي في حكم المخاصمة،دون أن يحتج في ذلك بالقول آن هذا استثناء،والاستئاء لا يقاس عليه،فإذا تفهمنا ذلك استطعنا أن نقضي علي الماصدي

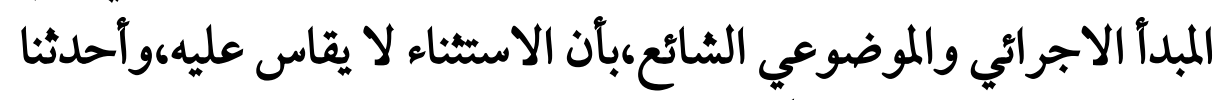

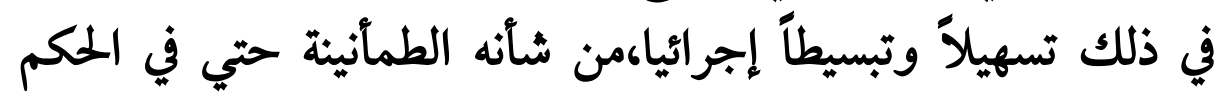
الصادر. 


\section{خاتهة البحث}

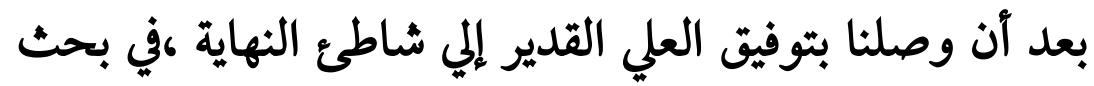

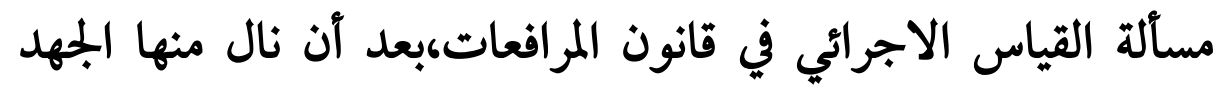

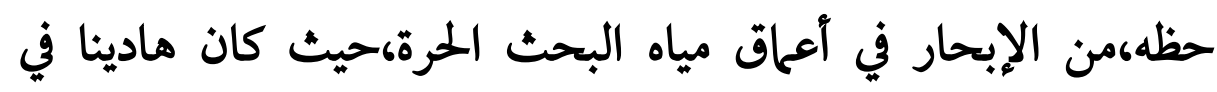

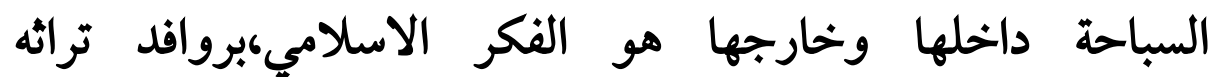
المغزارة،وينابيعه الصافية،نستطيع أن نحدد بإيجاز أهم نتائج هذاريا

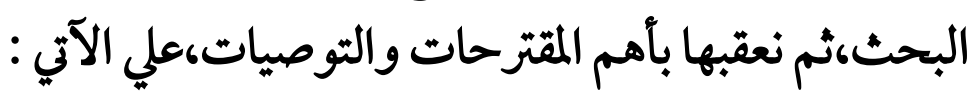

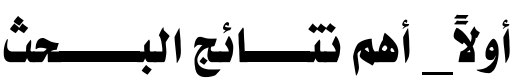

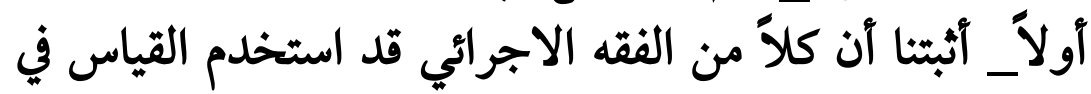

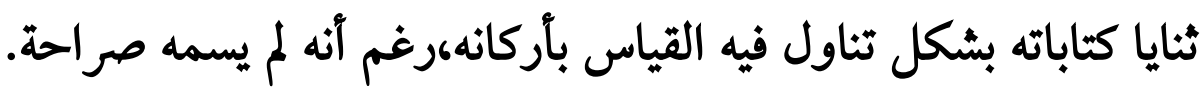
كا أثبتنا أن القضاء الاجرائيي قد استخدم القياس الاجرائي في فئي صور عمليةمتعددة.

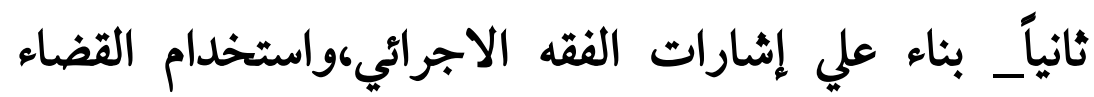

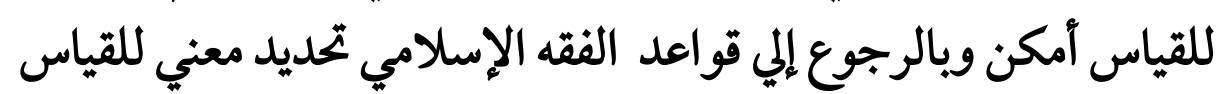
الاجرائي، انعتقد عقلانيته.

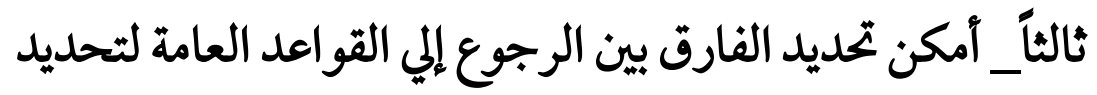
الاحكام الاجرائية،وبين القياس الاجرائي في استنباط تلك الأحكام

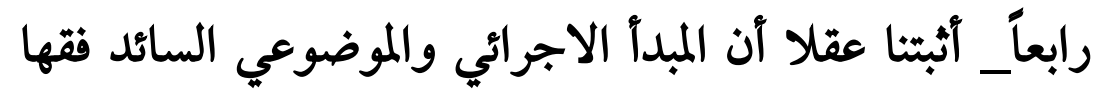

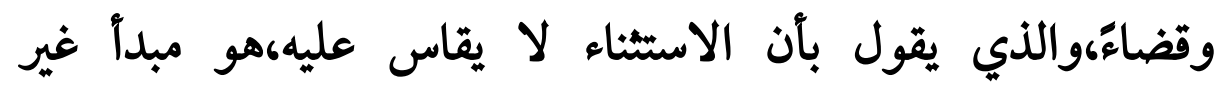
مقدس،وأمكن التدليل عقلاً علي إمكانية القياس عليه. 


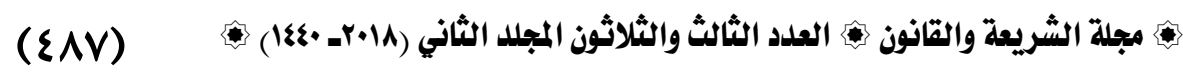

خامساً_ إنه وبحق لم يكن لي أن أبحث هذا الموضوع

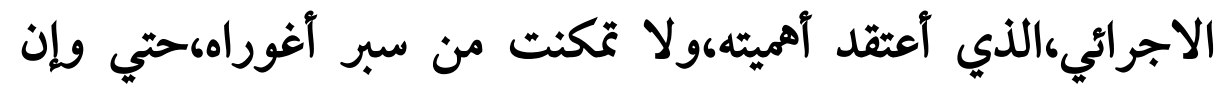

جانبني الصواب في تحرير مسائله وتدقيقها لولا استعانتي بالتراث

الفقهي الاسلامي ،الذي لازال يحتاج مني وضربائي الكثير والكثير.

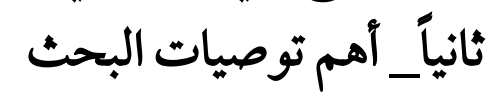

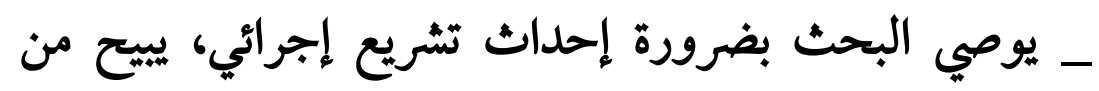

خلاله العمل بالقياس الاجرائي وفق ضوابطه وشروطه التي تناولما

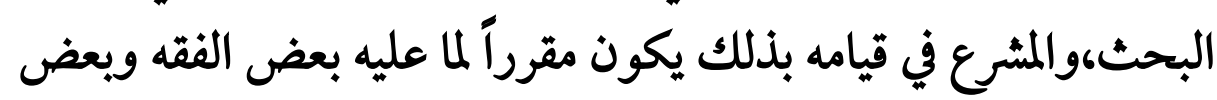

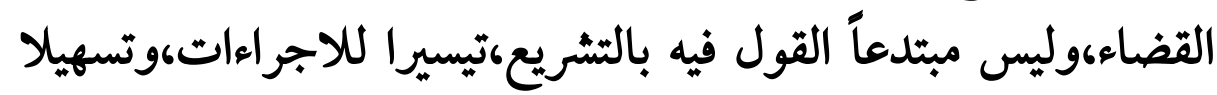

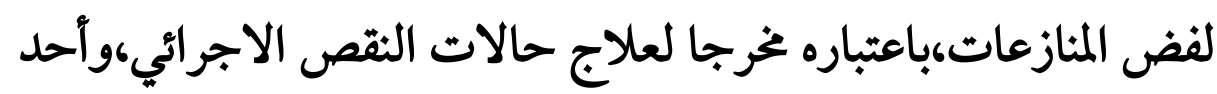

دلالات العرف العملي،الذي هو مصدر من مصادر القاعدة القانونية.

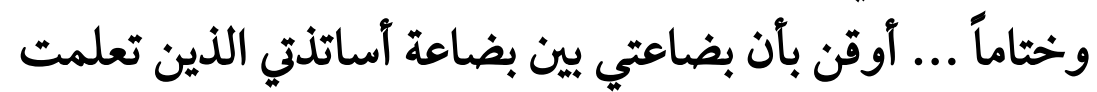

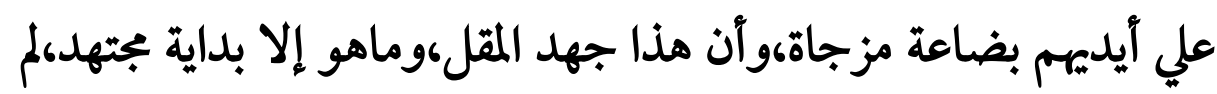

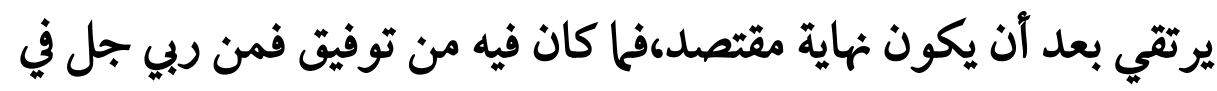

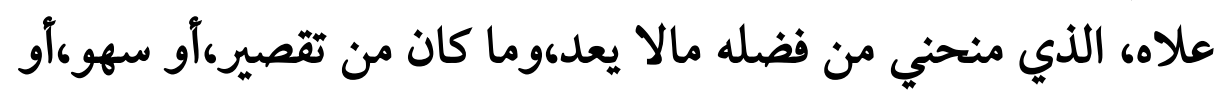

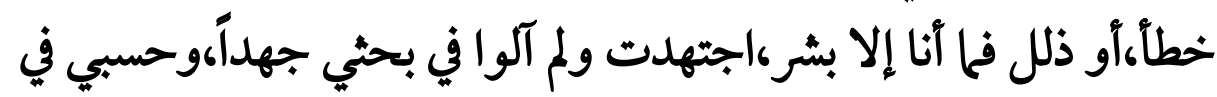
ذلك قول ربي (لا يكلف الله نفساً إلا ما آتاها). والله أسأل أن يتقبله خالصاً لوجه،وآن ينفع به،وأن يجعله صدقة جارية في ميزان أمي رحمها 


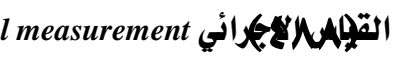

اللهافهي التي علمتني رغم أميتها.وآن يهب أبي مثل ثواب مااجتهدت

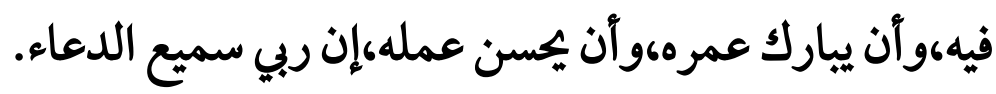




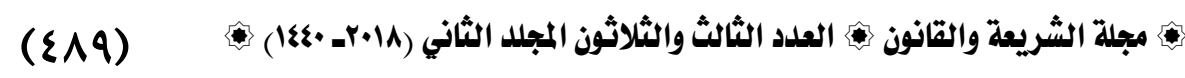
مراجع البحث

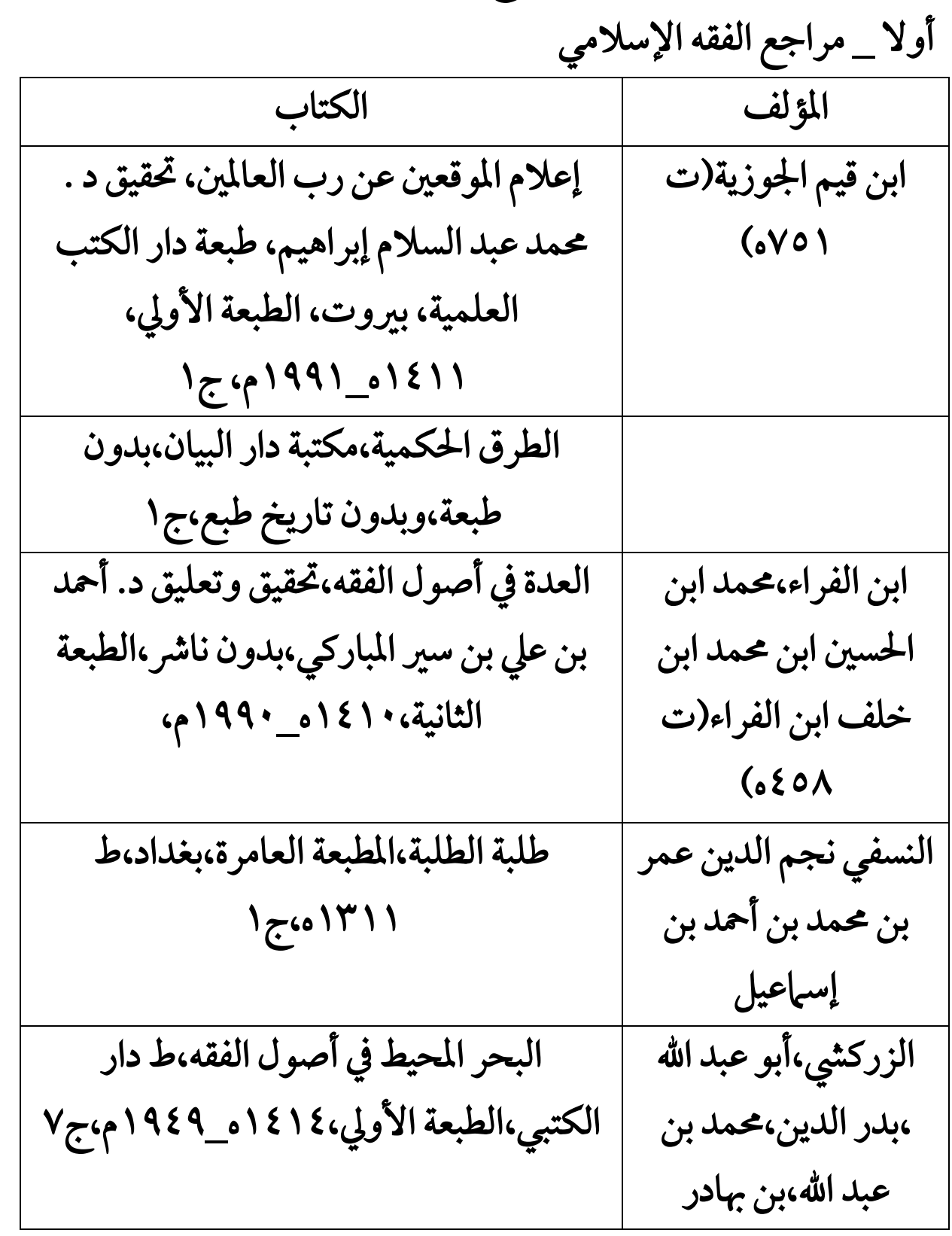




\begin{tabular}{|c|c|}
\hline 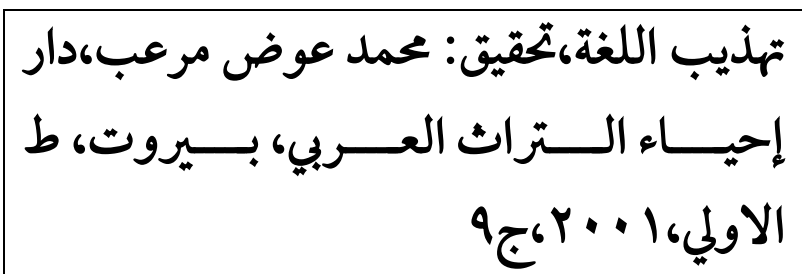 & المروي،محمد بن أحمد \\
\hline 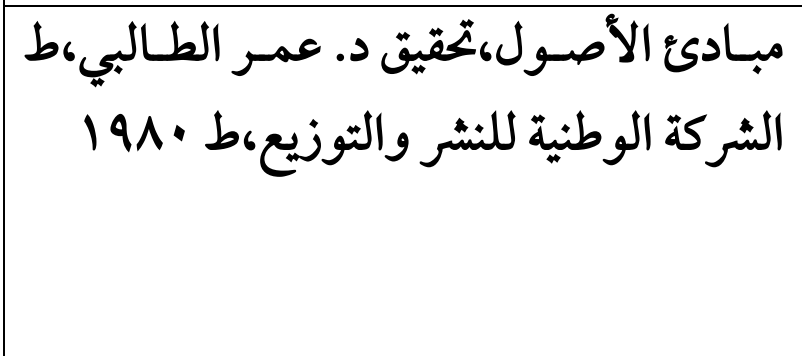 & $\begin{array}{c}\text { الصنهاجي، بحمبد الحميد } \\
\text { الصنهاجيس باديس } \\
\text { الحميس }\end{array}$ \\
\hline 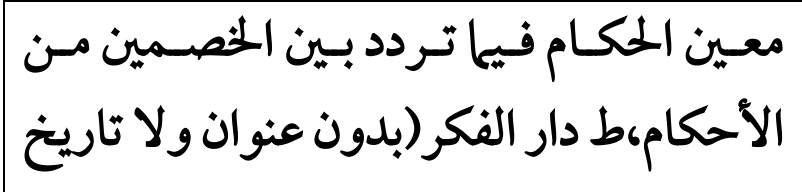 & الطرابلسي \\
\hline 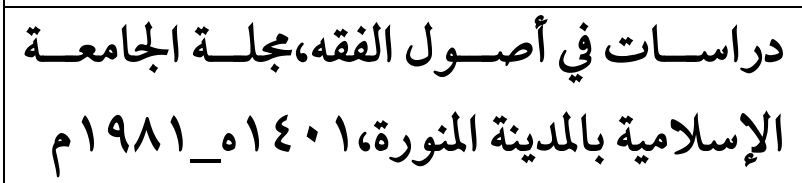 & \\
\hline 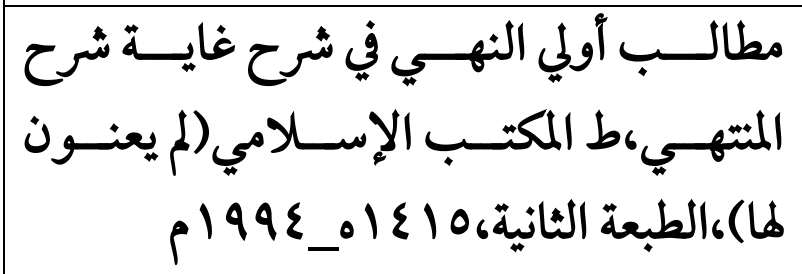 & $\begin{array}{c}\text { الرحيباني،مصطفي ابن ابن عبد السيوطي } \\
\text { الحنبلي }\end{array}$ \\
\hline 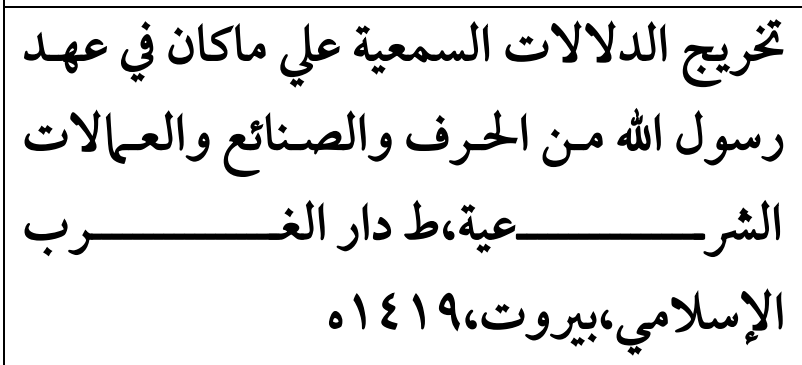 & 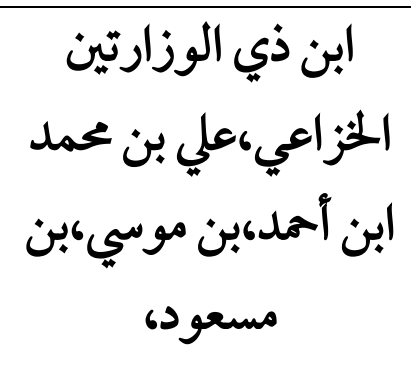 \\
\hline
\end{tabular}




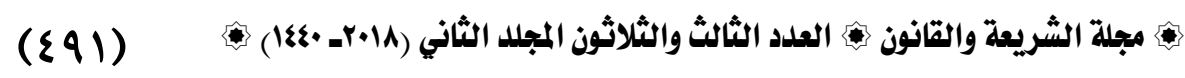

\begin{tabular}{|c|c|}
\hline 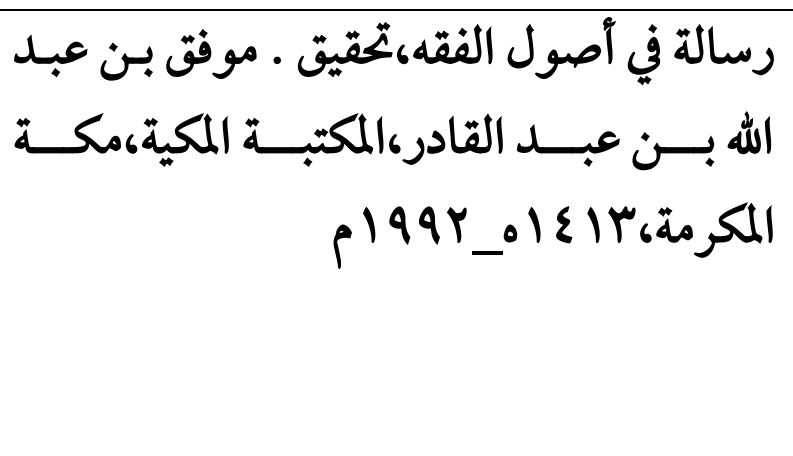 & 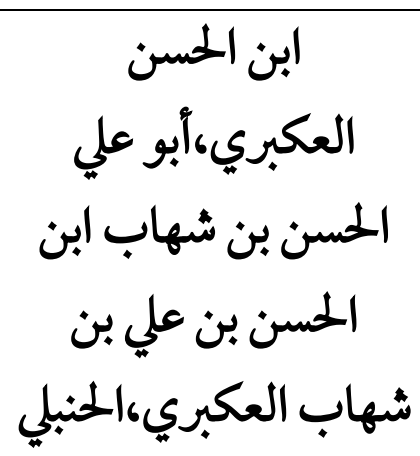 \\
\hline 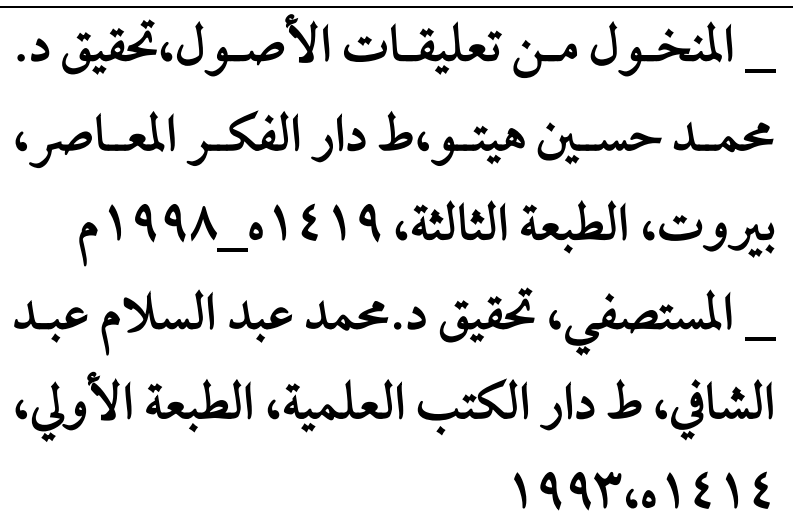 & 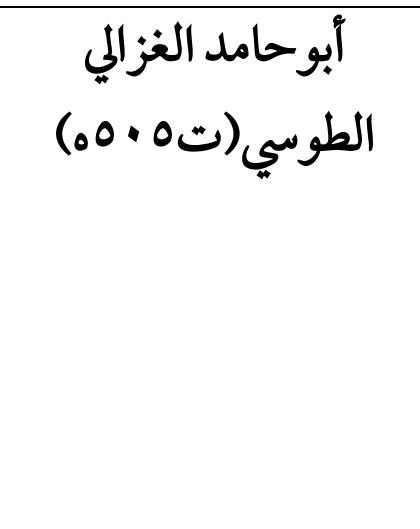 \\
\hline 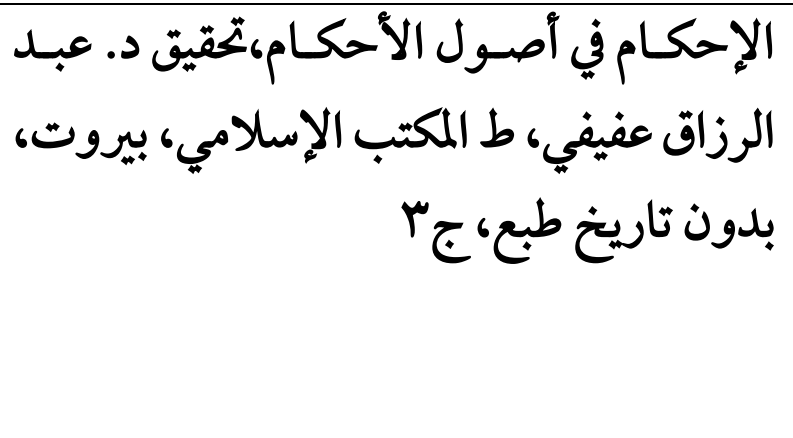 & 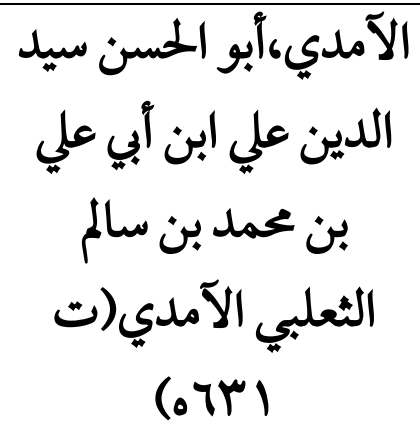 \\
\hline 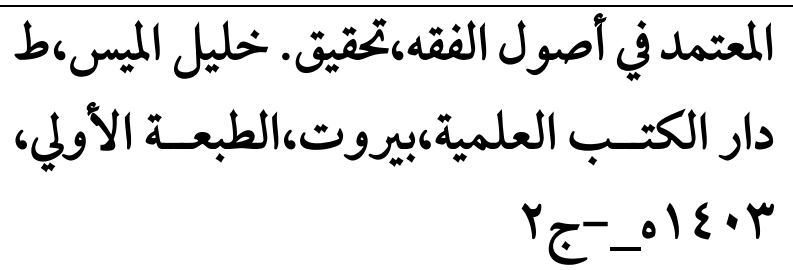 & أبوالحسين البصري(ت \\
\hline
\end{tabular}




\begin{tabular}{|c|c|c|}
\hline بأصــول الفقه،مكتبــة الدعوة،الطبعــة & علــمام & عبد الوهاب خلاف \\
\hline ل من علم الأصول،ط دار بن الجوزي & الأصو & صالح ابن محمد العثيمين \\
\hline & انونية & ثنانيا_المراجع الة \\
\hline 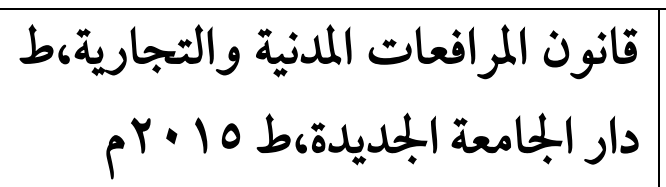 & & آ.د/ أحمد عوض هندي \\
\hline 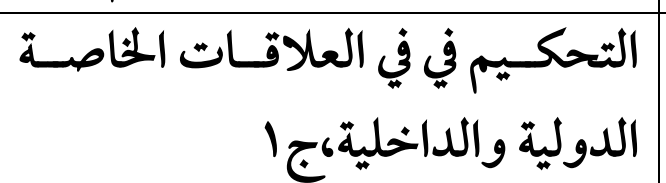 & 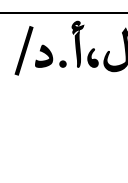 & 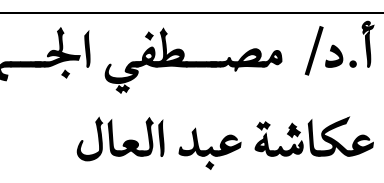 \\
\hline 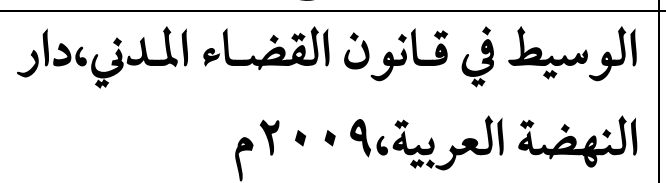 & & آ.د/ فتحي والي \\
\hline 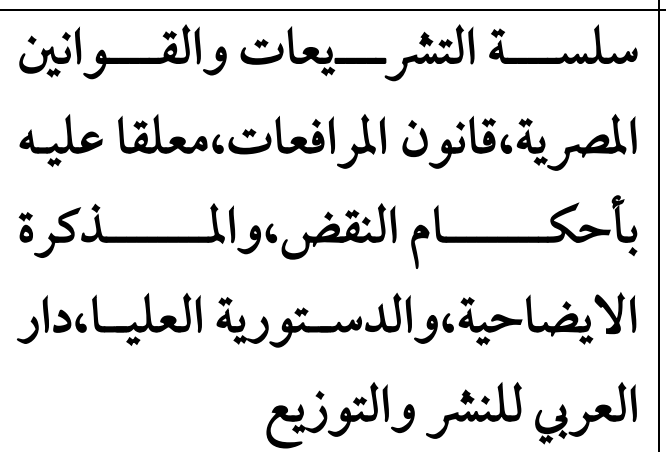 & & آسامة العربي \\
\hline
\end{tabular}


$(\varepsilon q \mu)$

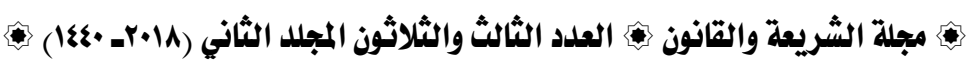

ثالثا_مجموعات الآحكام

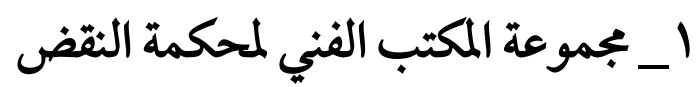

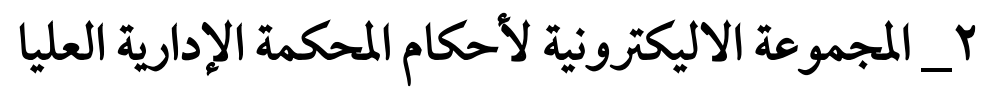

رابعا_المواقع الاليكترونية

ـ موقع محكمة النقض الاليكتروني 
فهرس البحث

\begin{tabular}{|c|c|c|}
\hline$\{r \mid$ & العمل بهة القياس وموقف الفقه الاجرائي والقضاء من & المبحث الأول \\
\hline$\{r \mid$ & حقيقة القياس في الفقه الاسلامي & المطلب الأول \\
\hline$\varepsilon r\}$ & : تعريف القياس لغة واصطلاحاً & الفرع الأول \\
\hline 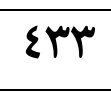 & تعريف القياس في اصطلاح الفقه الاسلامي. & الفرع الثاني \\
\hline$\varepsilon r \varepsilon$ & القضائية العملية المعني الفقي الاسلامي للقياس بالاجراءات & الفرع الثالث \\
\hline$\varepsilon r\}$ & آركان القياس وفقاً لمفهومه في الفقه الاسلامي & الفرع الرابع \\
\hline$\varepsilon r v$ & بذات معناه في الفقه الاجرائي والقضاء من العمل بالقياس & ل لب الثاني \\
\hline$\varepsilon r v$ & معناه في الفقه الاسلامي؟ الاجرائي القانوني القياس بذات & ع ع الأول \\
\hline$\varepsilon \varepsilon 0$ & 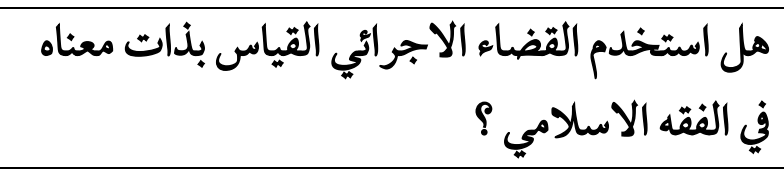 & 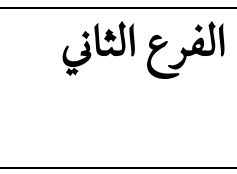 \\
\hline$\varepsilon T r$ & 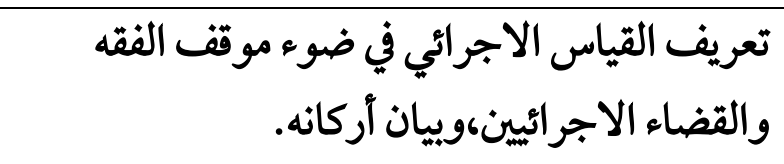 & الفرع الثالث \\
\hline$\varepsilon 70$ & أساس العمل بالقياس الاجرائي، إن & الفرع الرابع \\
\hline$\varepsilon 7 \tau$ & الفرق بين القياس ويين الرجوع إلي القواعد العامة. & الفرع الخامس \\
\hline$\varepsilon V Y$ & آنواع القياس الاجرائي وشروط العمل به. & المبحث الثاني \\
\hline$\varepsilon \vee \wedge$ & أنواع القياس الاجرائي & 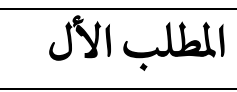 \\
\hline$\varepsilon V \mu$ & القياس الاجرائي الجلي & الفرع الأول \\
\hline
\end{tabular}




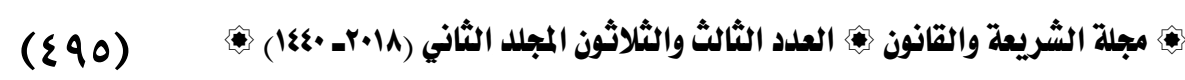

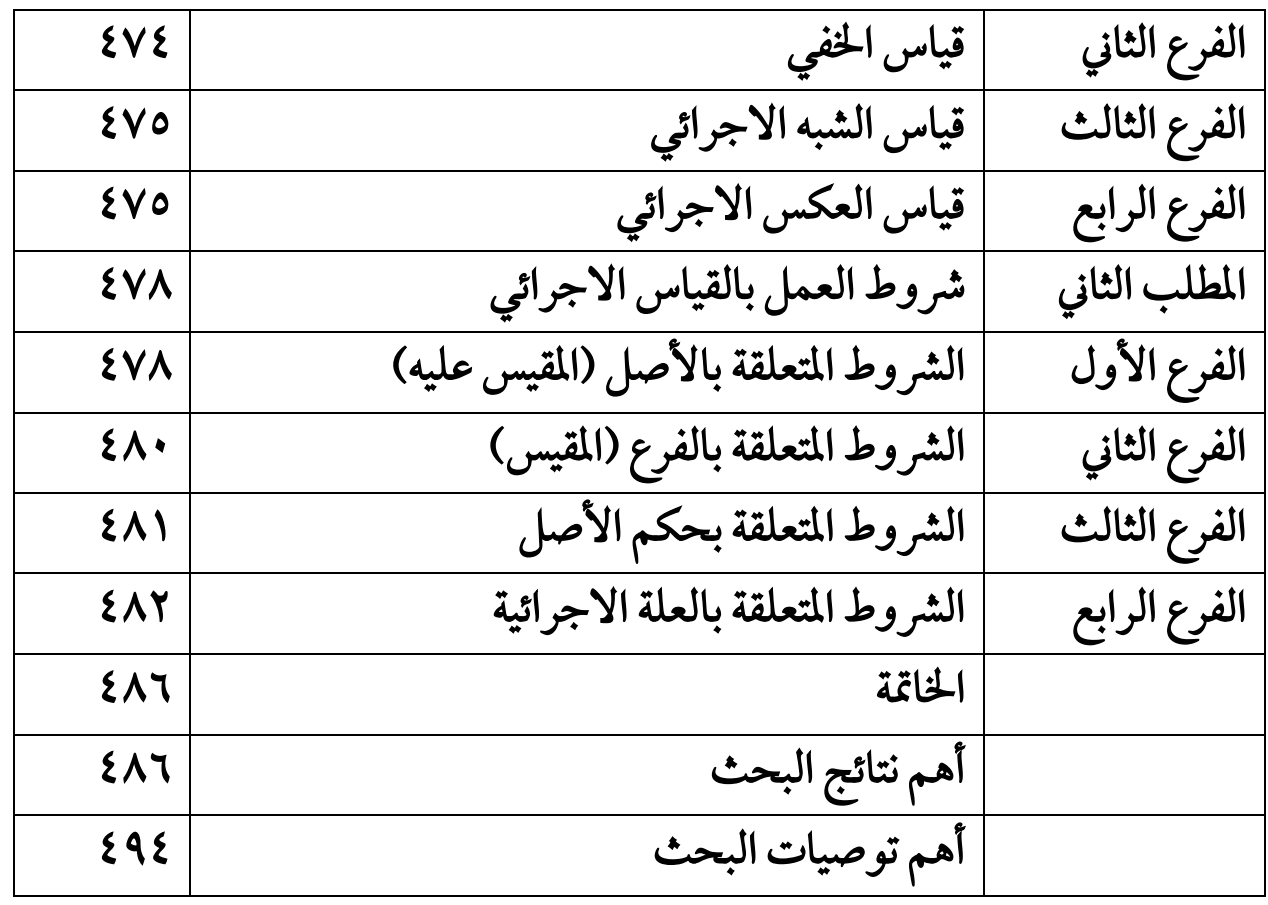

